\title{
Prehistoric Artifact Assemblages from Sites along Hickory Creek in the Davy Crockett National Forest, Houston County, Texas
}

Timothy K. Perttula

Heritage Research Center, Stephen F. Austin State University

Bo Nelson

Heritage Research Center, Stephen F. Austin State University

Follow this and additional works at: https://scholarworks.sfasu.edu/ita

Part of the American Material Culture Commons, Archaeological Anthropology Commons, Environmental Studies Commons, Other American Studies Commons, Other Arts and Humanities Commons, Other History of Art, Architecture, and Archaeology Commons, and the United States History Commons

Tell us how this article helped you.

This Article is brought to you for free and open access by the Center for Regional Heritage Research at SFA ScholarWorks. It has been accepted for inclusion in Index of Texas Archaeology: Open Access Gray Literature from the Lone Star State by an authorized editor of SFA ScholarWorks. For more information, please contact cdsscholarworks@sfasu.edu. 
Prehistoric Artifact Assemblages from Sites along Hickory Creek in the Davy Crockett National Forest, Houston County, Texas

\section{Creative Commons License}

\section{(c) (1) \&}

This work is licensed under a Creative Commons Attribution-NonCommercial 4.0 International License 


\section{PREHISTORIC ARTIFACT ASSEMBLAGES FROM SITES ALONG HICKORY CREEK IN THE DAVY CROCKETT NATIONAL FOREST, HOUSTON COUNTY, TEXAS}

Timothy K. Perttula and Bo Nelson

Submitted to U.S.D.A. Forest Service

National Forests and Grasslands in Texas

415 S. $1^{\text {st }}$ Street, Ste. 110

Lufkin, Texas 75901

Special Publication No. 14

Friends of Northeast Texas Archaeology and Archeological \& Environmental Consultants, LLC

Austin and Pittsburg, Texas

October 2009 


\section{TABLE OF CONTENTS}

List of Figures 3

$\begin{array}{ll}\text { List of Tables } & 7\end{array}$

$\begin{array}{ll}\text { Introduction } & 9\end{array}$

Site Settings

$\begin{array}{ll}\text { Prehistoric Artifacts from the Four Sites } & 13\end{array}$

Nature and Age of the Prehistoric Components at the Four Sites 69

Recommendations for Future Archeological Investigations and $\quad 70$

Artifact Analyses

$\begin{array}{ll}\text { End Notes } & 74\end{array}$

$\begin{array}{ll}\text { Acknowledgments } & 74\end{array}$

$\begin{array}{ll}\text { References Cited } & 74\end{array}$

Appendix 1, Inventory of Artifacts from the Hickory Creek \#2 Site, HC-2 80

Appendix 2, Inventory of Artifacts from HC-3 93

Appendix 3, Inventory of Artifacts from 41HO13 and HC-1 94 


\section{LIST OF FIGURES}

Figure 1. Location of the 2006-2007 PIT projects on Hickory Creek in Houston County, Texas. Ratcliff 7.5' USGS topographic quadrangle.

Figure 2. Map of the Hickory Creek 2 site and the location of excavation units; the location of the looter holes and back dirt piles is unknown.

Figure 3. Kiam Incised body sherd from HC-1, Unit 2, 10-20 cm bs.

Figure 4. Sandy paste Goose Creek Plain sherds and tempered-sandy paste plain rim sherds: a, parallel incised sandy paste; $b$, horizontal incised, grogtempered sandy paste; c, e-g, Goose Creek Plain rim sherds; d, plain hematite-tempered sandy paste rim. Provenience: a, Unit 5, 30-40 cm bs; b, Unit 3, 30-40 cm bs; c, Unit 6, 60-70 cm bs; d, Unit 3, 40-50 cm bs; e, Pothole 8; f, Unit 1, 60-70 cm bs; g, Unit 4A, 10-20 cm bs.

Figure 5. Horizontal brushed rim sherds from the Hickory Creek \#2 site. Provenience: a, Unit 3, 10-20 cm bs; b, Unit 2, 50-60 cm bs.

Figure 6. Selected decorative elements in the Hickory Creek \#2 site utility wares: a, g, brushed-punctated; b, brushed; c, Coles Creek Incised, var. Hardy; d-e, $\mathrm{h}$, incised; f, incised-punctated. Provenience: a, Unit 3, 0-10 cm bs; b-c, Unit 3, 10-20 cm bs; d, Unit 3, 20-30 cm bs; e, Unit 6, 10-20 cm bs;

f-g, Unit 3, 30-40 cm bs; h; Unit 3, 40-50 cm bs.

Figure 7. Parallel brushed body sherds from the Hickory Creek \#2 site.

Provenience: a-d, Unit 3, 20-30 cm bs.

Figure 8. Sherds with vertical brushing from the Hickory Creek \#2 site: a, vertical brushed; $b$, vertical brushed and grooved; $c$, roughened rim and vertical brushed body. Provenience: a, Unit 3A, 10-20 cm bs; b, Unit 3, 20-30 cm bs; c, Unit 2, 10-20 cm bs.

Figure 9. Brushed-incised and brushed-punctated sherds from the Hickory Creek \#2 site: a, c, brushed-incised; b, d, brushed-punctated. Provenience: a, c, Unit 3, 20-30 cm bs; b, Unit 4A, 70-80 cm bs; d, Unit 2, 0-10 cm bs. 26

Figure 10. Punctated rim and body sherds from the Hickory Creek \#2 site. Provenience: a, Unit 3, 30-40 cm bs; b, d, Unit 3, 20-30 cm bs; c, Unit 1, 20-30 cm bs; e, Unit 4, 10-20 cm bs; f, Unit 2, 20-30 cm bs. 


\section{LIST OF FIGURES, cont.}

Figure 11. Incised and incised-punctated rim and body sherds from the Hickory Creek \#2 site: a, cross-hatched incised; b, f, incised-punctated; c-d, incised lines; e, horizontal incised rim. Provenience: a, Pothole 8; b, Unit 4A, 80-90 cm bs; c, f Unit 3, 30-40 cm bs; d, Unit 3, 40-50 cm bs;

e, Unit 3, 20-30 cm bs.

Figure 12. Rim sherds from a Poynor Engraved, var. $B$ vessel (carinated bowl) from the Hickory Creek \#2 site. Provenience: a, c, Unit 3, 20-30 cm bs; b, Unit 3, 30-40 cm bs.

Figure 13. Selected engraved decorative elements in the Hickory Creek \#2 fine wares: a, Poynor Engraved, var. Cook; b, d, g, Poynor Engraved, var. B; c, f, diagonal engraved; e, cf. Poynor Engraved; h, opposed engraved lines; i, cross-hatched and negative triangle zone. Provenience: a, Unit 2, 10-20 cm bs; b, e, Unit 3, 20-30 cm bs; c, Unit 6, 20-30 cm bs; d, Unit 3, 10-20 cm bs; f, Unit 6, 10-20 cm bs; g, Unit 3, 30-40 cm bs; h-i, Unit 3, 40-50 cm bs.

Figure 14. Rim and body sherds from a Poynor Engraved, var. $B$ carinated bowl at the Hickory Creek \#2 site. Provenience: a, d, Unit 3, 10-20 cm bs; b-c, Unit 3, 20-30 cm bs.

Figure 15. Diagonal engraved rim and body sherds from a carinated bowl found in Area B of the Hickory Creek \#2 site. Provenience: a, Unit 6, 10-20 cm bs; b, Unit 6, 20-30 cm bs.

Figure 16. Other engraved rim sherds from the Hickory Creek \#2 site. Provenience: a, Unit 3, 40-50 cm bs; b, Unit 3, 20-30 cm bs.

Figure 17. Goose Creek Plain body sherds from HC-3. Provenience, Unit 1, 20-30 cm bs.

Figure 18. Plain pipe bowls from Red River long-stemmed pipes at the Hickory Creek \#2 site. Provenience: a, Unit 3, 20-30 cm bs; b, Unit 3, $30-40 \mathrm{~cm}$ bs.

Figure 19. Clovis point from the Hickory Creek \#2 site: a, side A; b, side B.

Figure 20. Projectile points from 41HO13: a, Kent dart point; b, cf. Steiner arrow point. Provenience: a, Unit 1, 100-110 cm bs; b, Unit 1, $40-50 \mathrm{~cm}$ bs.

Figure 21. Dart points from HC-1: $a$, Gary point; $b$, Kent point. Provenience: a, Unit 1 back dirt; b, Unit 1A, 80-90 cm bs. 


\section{LIST OF FIGURES, cont.}

Figure 22. Selected dart points from the Hickory Creek \#2 site: a, Big Sandy; b, Yarbrough; c, unidentified expanding stem; d, Lone Oak; e, cf. Godley. Provenience: a, Unit 1, 10-20 cm bs; b, Unit 3 back dirt; c, Unit 1, 80-90 cm bs; d, Unit 1, 70-80 cm bs; e, Unit 4, 70-80 cm bs.

Figure 23. Parallel-stemmed dart points: a, g-h, cf. Bulverde; b, d-e, Morrill; c, unidentified parallel stemmed; f, Godley. Provenience: a, Unit 6, $50 \mathrm{~cm}$ bs; b, d, Looter Hole 3 back dirt; c, Unit 1, 40-50 cm bs; e, Looter Hole 4; f, Unit 1, 70-80 cm bs; g, Unit 4, 50-60 cm bs; h, Unit 6, 30-40 cm bs.

Figure 24. Dart points from the Hickory Creek \#2 site: a, Woden; b, Kent; c, Morrill; d, cf. Morrill. Provenience: a, Looter Hole 2, back dirt; b, Unit 5, 50-60 cm bs; c, Unit 6, $72 \mathrm{~cm}$ bs; d, Unit 4A, $50-60 \mathrm{~cm}$ bs.

Figure 25. Kent dart points and other dart points: a, c, e, g-i, Kent; b, unidentified contracting stem (novaculite); d, Neches River; f, Gary. Provenience: a, e, Unit 1, 70-80 cm bs; b, Unit 6, $80 \mathrm{~cm}$ bs; c, Unit 3, back dirt; d, Unit 6, 40-50 cm bs; f, Unit 2, 50-60 cm bs; g, Unit 2, 60-70 cm bs; h, Unit 6, $72 \mathrm{~cm}$ bs; i, Unit 1, 60-70 cm bs.

Figure 26. Gary dart points. Provenience: a, Unit 4, 60-70 cm bs; b, Unit 2, 40-50 cm bs; c, Unit 3A, 40-50 cm bs; d, Unit 6, 10-20 cm bs; e, Unit 4A, 40-50 cm bs; f, Unit 5, 30-40 cm bs; g, Unit 1, $40-50 \mathrm{~cm}$ bs.

Figure 27. Contracting stem Gary dart points from the Hickory Creek \#2 site. Provenience: a, Unit 2, 50-60 cm bs; b, Looter Hole 8; c, Unit 2, 20-30 cm bs; d, Unit 2, 60-70 cm bs; e, Unit 3A, 40-50 cm bs; f, Unit 4, 60-70 cm bs; g, Unit 4, 70-80 cm bs.

Figure 28. Dart points from HC-3: a, c, Kent; b, Bulverde. Provenience: a, c, Unit 1, 40-50 cm bs; b, Unit 1, 20-30 cm bs.

Figure 29. Early arrow point forms at the Hickory Creek \#2 site: a-b, Friley; c, e, Steiner; d, Alba. Provenience: a, Unit 2, 40-50 cm bs; b-c, Unit 3 back dirt; d, Unit 4A, lv. 9, back dirt; e, Unit 2, 50-60 cm bs. 


\section{LIST OF FIGURES, cont.}

Figure 30. Perdiz, Perdiz-Bonham, and Steiner arrow points from the Hickory Creek \#2 site: a-d, f-n, Perdiz; e, cf. Steiner; o, Perdiz-Bonham. Provenience: a, j-k, Unit 3, 20-30 cm bs; b-c, 1, Unit 3, 10-20 cm bs; d, Unit 3A, 0-10 cm bs; e, Unit 3A, 10-20 cm bs; f, h, Unit 6, 0-10 cm bs; g, i, Unit 4, 0-10 cm bs; m, Unit 6, 10-20 cm bs; n, Unit 4, 20-30 cm bs;

o, Unit 1, 10-20 cm bs.

Figure 31. Bifaces from the Hickory Creek \#2 site. Provenience: a, Unit 6, 70-80 cm bs; b, Pothole 8; c, Unit 6, 60-70 cm bs; d, Unit 6, 40-50 cm bs; e-f, Unit 4, 50-60 cm bs; g, Unit 2, 30-40 cm bs.

Figure 32. Bifacial tools and preforms: a, bifacial scraper; b, gouge; c, chert bifacial preform. Provenience: a, Unit 3, 40-50 cm bs; b, Pothole 8; c, Unit 2, 60-70 cm bs.

Figure 33. Flake tools and a drill from the Hickory Creek \#2 site: a-c, e-h, expedient flake tools; d, drill. Provenience: a, Unit 4, 60-70 cm bs; b-c, Unit 1, 60-70 cm bs; d, Unit 3, 20-30 cm bs; e, g, Pothole 5; f, Unit 4A, 80-90 cm bs; h, Unit 4, 50-60 cm bs.

Figure 34. Selected cores from the Hickory Creek \#2 site: a, quartzite; b, Glover quartzite; c, petrified wood. Provenience: a, Unit 4A, 50-60 cm bs; b, Unit 4, 40-50 cm bs; c, Unit 6, 30-40 cm bs.

Figure 35. Pigment stone with a drilled hole from Unit 1, 50-60 cm bs, at the Hickory Creek \#2 site. 


\section{LIST OF TABLES}

Table 1. Prehistoric artifacts from the Hickory Creek sites.

Table 2. Prehistoric artifacts from the Hickory Creek \#2 site (HC-2) units and looter pits (LP).

Table 3. Density of Prehistoric artifacts from the Hickory Creek \#2 site (HC-2) units per square meter of archeological deposits.

Table 4. Prehistoric artifacts from the Hickory Creek \#2 site (HC-2) by depth, all units.

Table 5. Prehistoric artifacts from HC-3.

Table 6. Dated sites in eastern Texas and southwestern Louisiana with Goose Creek Plain ceramic sherds.

Table 7. Decorated utility ware sherds from the Hickory Creek \#2 site.

Table 8. Decorative elements on fine ware sherds from the Hickory

Table 9. Temper choice in the ceramic sherds from the Hickory Creek \#2 site.

Table 10. Provenience of dart points and dart point fragments from the Hickory Creek \#2 site, Area A.

Table 11. Provenience of dart points and dart point fragments from the Hickory Creek \#2 site, Area B.

Table 12. Summary of dart points by period, area, and depth from the Hickory Creek \#2 site.

Table 13. Lithic raw material use in the dart points from the Hickory

Table 14. Provenience of arrow points from the Hickory Creek \#2 site. 55

Table 15. Lithic raw material use in the arrow points from the Hickory 58 Creek \#2 site.

Table 16. Raw materials represented in the lithic debris from excavation $\quad 62$ levels by Unit. 


\section{LIST OF TABLES, cont.}

Table 17. Levels with the highest proportion of the different lithic raw materials in the lithic debris.

Table 18. Distribution of animal bone by provenience and depth at the Hickory Creek \#2 site. 


\section{INTRODUCTION}

The National Forests and Grasslands (U.S.D.A. Forest Service) in Texas (NFGT) conducted Passports in Time (PIT) projects in 2006 and 2007 on Hickory Creek in the Davy Crockett National Forest, Houston County, Texas (Figure 1). The work-varying in extent — took place at four prehistoric archeological sites: 41HO13, HC-1, Hickory Creek \#2 (HC-2), and HC-3, with the majority of the work occurring at HC-2. ${ }^{1}$

We learned of the PIT projects at the sites in April 2007, when John Ippolitto, then Heritage Program Manager for the NFGT, mentioned the project to Perttula at the Annual Meeting of the Society for American Archaeology held in Austin, Texas.

Ippolitto told Perttula that the NFGT was working on a prehistoric Caddo site that had been previously looted (the looting had been discovered by a district archeologist for the NFGT in 2005; Barbara J. Williams, 2009 personal communication), and that the site contained a large number of Caddo pottery sherds of an unknown age. Perttula expressed an interest in learning more about the site, given work he was involved in elsewhere in the Neches River basin of East Texas, and offered his time in assisting with the analysis of the recovered artifacts.

Nothing more was heard from the NFGT for more than a year about the site or the collections, by which time Barbara J. Williams had taken over as the Heritage Program Manager of the NFGT. In the fall of 2008, Perttula contacted Williams about the Hickory Creek sites PIT project, and after some discussion, the NFGT agreed to turn over the collections and available notes/records (from, as it turned out, four separate sites along Hickory Creek) in February 2009 to Perttula for the purposes of completing a volunteer analysis of these collections and preparing a report on the analytical findings. This report represents the findings of the analysis of the prehistoric artifacts recovered from the $\mathrm{HC}$ 1, Hickory Creek \#2 (HC-2), HC-3, and 41HO13 sites during the 2006 and 2007 PIT projects.

\section{SITE SETTINGS}

Hickory Creek is an eastward-flowing tributary of the Neches River in the East Texas Pineywoods (Diggs et al. 2006). Hickory Creek merges with the Neches River about $12 \mathrm{~km}$ below the southernmost El Camino Real de los Tejas crossing of the river, and the mouth of the creek is approximately $14 \mathrm{~km}$ from the Early Caddo (ca. A.D. 8501300) mound center at the George C. Davis site (41CE19) (Story 2000; Newell and Krieger 2000). The Hickory Creek sites are about $8 \mathrm{~km}$ upstream from its confluence with the Neches River.

HC-1 and HC-3 are situated on upland toe slopes or alluvial fans (ca. 240 feet amsl) overlooking the Hickory Creek floodplain to the south (see Figure 1). $41 \mathrm{HO} 13$ is higher on the same landform (250 feet amsl), and not far north of HC-1. The Hickory 

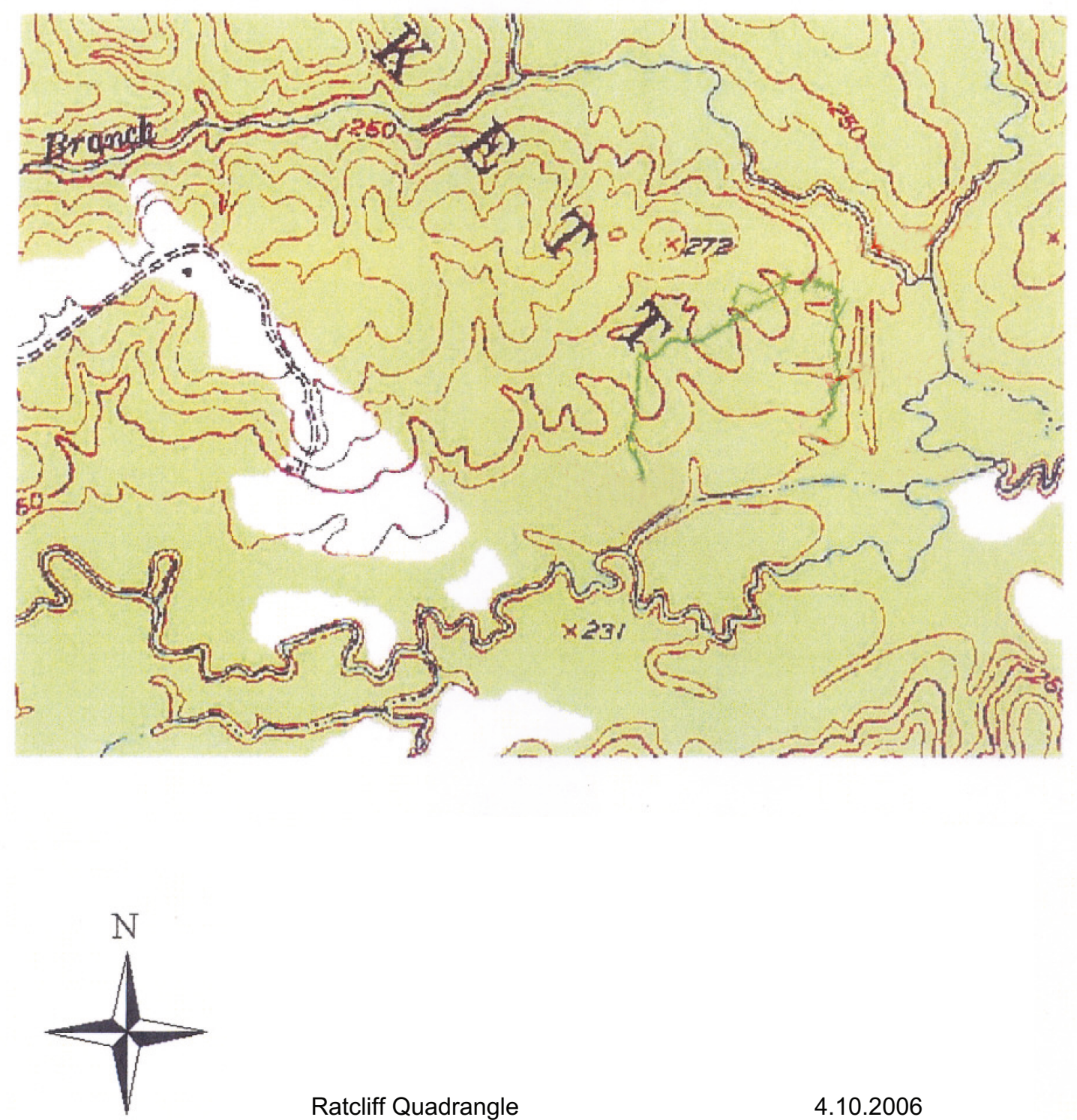

Ratcliff Quadrangle

4.10 .2006

\section{Figure 1. Location of the 2006-2007 PIT projects on Hickory Creek in Houston County, Texas. Ratcliff 7.5' USGS topographic quadrangle.}

Creek \#2 site (HC-2) is located on an alluvial rise (ca. 230 feet amsl) next to an old channel of Hickory Creek, about 350-400 m west of HC-1 and HC-3 (see Figure 1).

The few prehistoric artifacts from $\mathrm{HC}-1$ came from the excavation of two units (Units 1 and 2) of unknown size, and from an area of back dirt associated with Unit 1; there are no available field notes and unit forms. Unit 1 (and Unit 1A) was excavated to at least $90 \mathrm{~cm} \mathrm{bs}$, based on the recovery of artifacts from that depth, and Unit 2 (and Unit 2A) was excavated to at least $20 \mathrm{~cm}$ bs. Almost all the artifacts from the site are chipped and ground stone tools as well as pottery sherds, but only one piece of lithic debris (from Unit 1A). It seems likely that there are additional archeological materials from HC-1 that 
have not been made available for study, since lithic debris is otherwise very abundant at the Hickory Creek \#2 and HC-3 sites.

PIT project archeological investigations at the Hickory Creek \#2 site (HC-2) included in 2006 the removal and screening the fill and back dirt from four looter pits (\#3, 4, 5, and 8). ${ }^{2}$ In 2007, seven excavation units (Unit 1-7) of varying sizes were handexcavated to a maximum depth of $90 \mathrm{~cm}$ bs in the archeological deposits at the Hickory Creek \#2 site (Figure 2). The units ranged from $2 \times 2 \mathrm{~m}$ in size (Unit 2, 4, and 7) to $3 \times 3$ $\mathrm{m}$ in size (Units 1, 3, 5, and 6). Based on placement of units across the landform, Units 14 are part of Area A at the site, while Units 5-7 are in Area B.

During the excavations, no obvious features were encountered in the archeological deposits, but a concentration of ceramic sherds, animal bones, and other domestic refuse was noted between $30-40 \mathrm{~cm}$ bs that may represent an occupational surface or the unprepared floor to a prehistoric Caddo house structure. A sample of unburned animal bones from Unit $3(29-35 \mathrm{~cm}$ bs) in Area A was submitted to Beta Analytic, Inc., for radiocarbon dating, and a conventional age of $510 \pm 40$ B.P. (A.D. 1400-1480) was obtained from those remains. ${ }^{3}$ The calibrated radiocarbon intercept is AD 1421 (Reimer et al. 2004).

As with $\mathrm{HC}-1$, the few prehistoric artifacts from $41 \mathrm{HO} 13$ came from the excavation of two units (Units 1 and 2) of unknown size; there are no available NFGT field notes and unit forms. Unit 1 was excavated to at least $120 \mathrm{~cm}$ bs, and Unit 2 was excavated to at least $70 \mathrm{~cm}$ bs. Since the only artifacts from the site are chipped and ground stone tools, it is likely that there are additional archeological materials from $41 \mathrm{HO} 13$ that have not been made available for study.

A single 1 x 1 m unit (Unit 1) was excavated at HC-3. Prehistoric lithic and ceramic artifacts were recovered between $0-70 \mathrm{~cm}$ bs as well as from a single looter hole (Hole 2). 


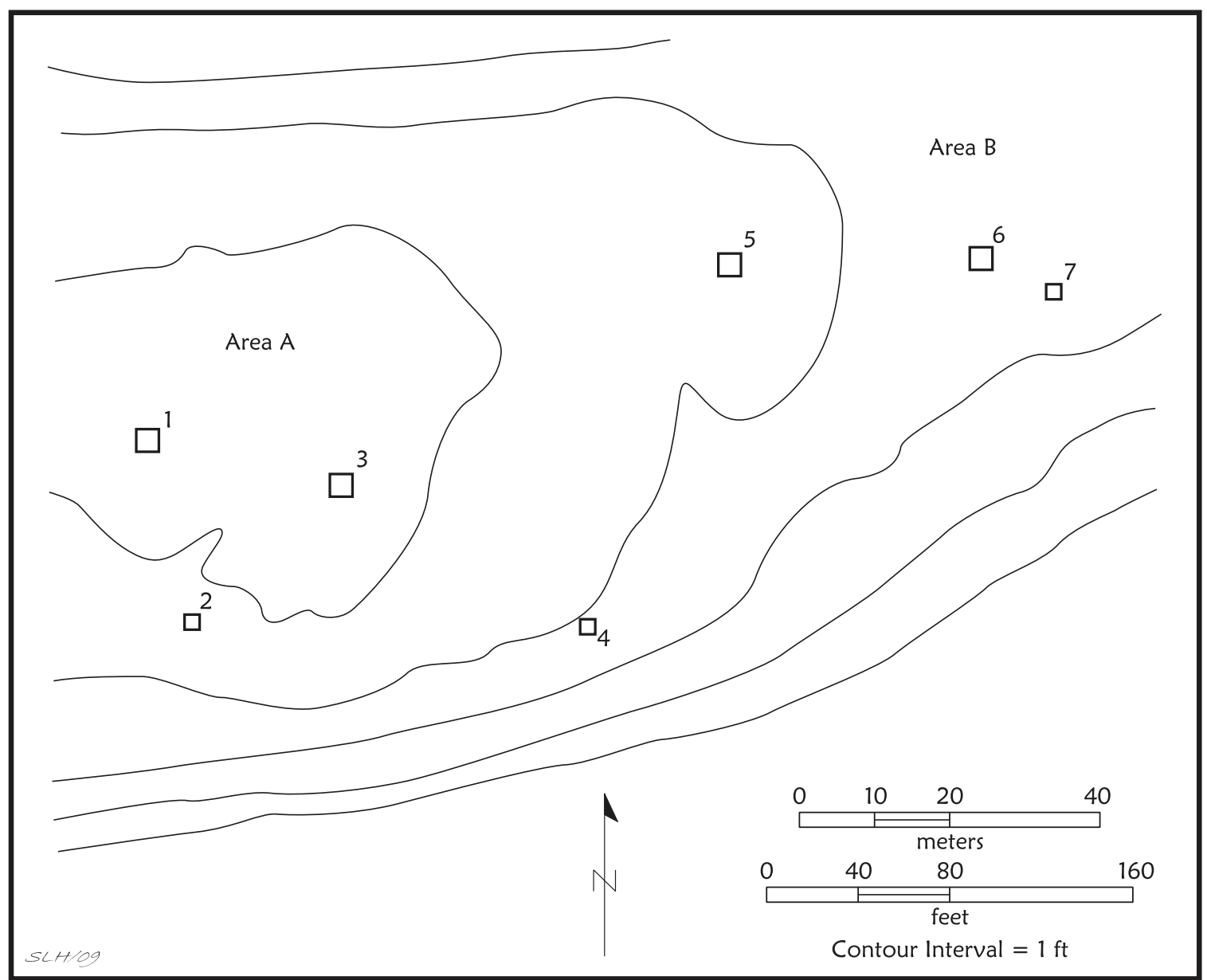

Figure 2. Map of the Hickory Creek \#2 site and the location of Units 1-7. Map prepared by Sandra Hannum.

\section{PREHISTORIC ARTIFACTS FROM THE FOUR SITES}

A wide variety of prehistoric lithic and/or ceramic artifacts were recovered during the two years of the PIT project archeological investigations at four prehistoric sites on Hickory Creek (Appendix 1-3). This includes prehistoric lithic tools (both chipped and ground stone) and debris, plain and decorated ceramic rim, body, and base sherds, ceramic pipe sherds, as well as burned clay/daub, and fire-cracked rock; animal bones and charred plant remains were also present at HC-2 (see below), but they are not the subject of this report. The vast majority of artifacts (97\%) from the PIT project are from the Hickory Creek \#2 (HC-2) site (Table 1). 
Table 1. Prehistoric artifacts from the Hickory Creek sites.

\begin{tabular}{llllllllllll}
\hline Site & DP & BIF & AP & FT & LD & FCR & GS & PS & DS & BC/D & N \\
\hline HO13 & 1 & - & 1 & 1 & - & - & 1 & - & - & - & 4 \\
HC-1 & 3 & - & - & - & 1 & - & - & 1 & 1 & - & 6 \\
HC-2 & 78 & 49 & 34 & 45 & 10381 & 78 & 18 & $292 *$ & 144 & 58 & 11177 \\
HC-3 & 5 & 1 & - & 5 & 277 & - & 2 & 13 & - & - & 303 \\
\hline Totals & 87 & 50 & 35 & 51 & 10659 & 78 & 21 & 306 & 145 & 58 & 11490 \\
\hline *includes 6 plain pipe sherds & & & & & & & & & & &
\end{tabular}

Among the recovered artifacts, about $93 \%$ are pieces of lithic debris (see Table 1). Plain and decorated sherds, as well as ceramic pipe sherds, comprise $3.9 \%$ of the artifact collection, while chipped stone tools account for another $2 \%$ of the artifacts.

At the Hickory Creek \#2 site, there are high densities of prehistoric archeological materials across the landform, particularly in Units 1, 3-6 and Looter Pit 8 (Table 2). The same range of prehistoric lithic and ceramic artifacts occur across the site, but there are some notable differences in the frequency of dart points (concentrations in Units 1, 4, and 6, as well as Looter Pits 3 and 8), lithic debris (Unit 4), arrow points (concentrated in Unit 3), plain and decorated sherds (concentrated in Unit 3, as are pipe sherds), as well as burned clay/daub (Unit 3).

Table 2. Prehistoric artifacts from the Hickory Creek \#2 site (HC-2) units and looter pits (LP).

Unit DP BIF AP FT $\mathrm{LD}$ FCR $\mathrm{GS}$ PS $\mathrm{DS}$ BC/D N

\begin{tabular}{llllllllllll}
\hline 1 & 18 & 4 & 2 & 9 & 1567 & 20 & 6 & 34 & 14 & 5 & 1679 \\
2 & 6 & 3 & 3 & 4 & 692 & 5 & 3 & 20 & 12 & - & 748 \\
3 & 4 & 3 & 13 & 4 & 1363 & 4 & 2 & $141+$ & 97 & 43 & 1674 \\
4 & 12 & 19 & 5 & 9 & 2602 & 11 & 2 & 35 & 8 & 4 & 2707 \\
5 & 9 & 5 & 2 & 6 & 1400 & 6 & 2 & - & 1 & 2 & 1433 \\
6 & 14 & 11 & 5 & 7 & 1233 & 17 & 2 & $25^{*}$ & 7 & - & 1321 \\
7 & - & - & 1 & - & 276 & - & - & - & - & - & 277
\end{tabular}


Table 2. Prehistoric artifacts from the Hickory Creek \#2 site (HC-2) units and looter pits (LP), cont.

\begin{tabular}{llllllllllll}
\hline Unit & DP & BIF & AP & FT & LD & FCR & GS & PS & DS & BC/D & N \\
\hline LP3 & 8 & - & 2 & 1 & 180 & 5 & - & 10 & 1 & 3 & 210 \\
LP4 & 1 & & - & - & 39 & - & - & 1 & 1 & - & 42 \\
LP5 & - & 1 & - & 1 & 236 & 5 & 1 & 13 & 1 & - & 258 \\
LP8 & 6 & 3 & 1 & 4 & 775 & 5 & - & 13 & 2 & 1 & 810 \\
\hline
\end{tabular}

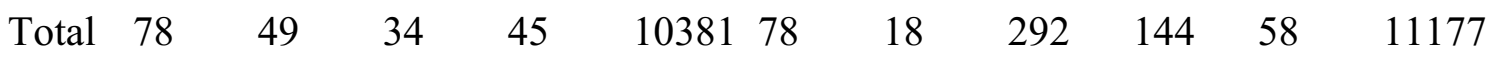

$\mathrm{DP}=$ dart point; $\mathrm{BIF}=$ biface; $\mathrm{AP}=$ arrow point; $\mathrm{FT}=$ flake tool; $\mathrm{LD}=$ lithic debris and cores; $\mathrm{GS}=$ ground stone tool; $\mathrm{PS}=$ plain sherd; $\mathrm{DS}=$ decorated sherd; $\mathrm{BC} / \mathrm{D}=$ burned clay/daub *includes one plain pipe sherd; +includes five plain pipe sherds

Converting the artifact frequency data to artifacts per square meter further confirms the fact that there are intra-site differences in the densities of different artifact classes, which has implications for unraveling the prehistoric use of the Hickory Creek \#2 (HC-2) site. Dart points, bifaces (mostly broken and fragmentary pieces, see below), flake tools, and lithic debris are concentrated in the area of Unit 4 in the southern part of the site, as are fire-cracked rock and total numbers of artifacts per square meter (Table 3 ). Clearly, Unit 4 was placed in an area of the site where lithic tool manufacture was emphasized (most likely the manufacture of bifacial tools), along with the use and discard of projectile points and flake tools. Activities involving fire-cracked rock-most likely the hot rock cooking of various plant foods (see Thoms 2008) — were also more common in the southern part of the site.

Table 3. Density of Prehistoric artifacts from the Hickory Creek \#2 site (HC-2) units per square meter of archeological deposits.

\begin{tabular}{|c|c|c|c|c|c|c|c|c|c|c|c|}
\hline Unit & DP & BIF & AP & FT & LD & FCR & GS & PS & DS & $\mathrm{BC} / \mathrm{D}$ & $\mathrm{N}$ \\
\hline \multicolumn{12}{|c|}{ Western area } \\
\hline 1 & 2.0 & 0.4 & 0.2 & 1.0 & 175.2 & 2.2 & 0.7 & 3.8 & 1.6 & 0.6 & 186.6 \\
\hline 2 & 1.5 & 0.8 & 0.8 & 1.0 & 173.0 & 1.3 & $\underline{0.8}$ & 5.0 & 3.0 & - & 187.0 \\
\hline 3 & 0.4 & 0.3 & $\underline{1.4}$ & 0.4 & 151.4 & 0.4 & 0.2 & $15.7^{*}$ & $\underline{10.8}$ & $\underline{4.8}$ & 186.0 \\
\hline \multicolumn{12}{|c|}{ Southern area } \\
\hline 4 & $\underline{3.0}$ & $\underline{4.8}$ & 1.3 & $\underline{2.3}$ & $\underline{650.5}$ & $\underline{2.8}$ & 0.5 & 8.8 & 2.0 & 1.0 & $\underline{676.8}$ \\
\hline
\end{tabular}


Table 3. Density of Prehistoric artifacts from the Hickory Creek \#2 site (HC-2) units per square meter of archeological deposits, cont.

\begin{tabular}{|c|c|c|c|c|c|c|c|c|c|c|c|}
\hline Unit & $\mathrm{DP}$ & $\mathrm{BIF}$ & AP & FT & LD & FCR & GS & PS & DS & $\mathrm{BC} / \mathrm{D}$ & $\mathrm{N}$ \\
\hline \multicolumn{12}{|c|}{ Eastern area } \\
\hline$\overline{5}$ & 1.0 & 0.6 & 0.2 & 0.7 & 144.4 & 0.7 & 0.2 & - & 0.1 & 0.2 & 159.2 \\
\hline 6 & 1.6 & 1.2 & 0.6 & 0.8 & 137.0 & 1.9 & 0.2 & $2.8^{*}$ & 0.8 & - & 146.8 \\
\hline 7 & - & - & 0.3 & - & 69.0 & - & - & - & - & - & 69.3 \\
\hline
\end{tabular}

$\mathrm{DP}=$ dart point; $\mathrm{BIF}=$ biface; $\mathrm{AP}=$ arrow point; $\mathrm{FT}=$ flake tool; $\mathrm{LD}=$ lithic debris and cores;

$\mathrm{GS}=$ ground stone tool; $\mathrm{PS}=$ plain sherd; $\mathrm{DS}=$ decorated sherd; $\mathrm{BC} / \mathrm{D}=$ burned clay/daub; *includes pipe sherds

In the western part of the Hickory Creek \#2 site, the highest densities of arrow points - and the only unit where the density of arrow points is higher than the density of dart points - is in Unit 3 (see Table 3). This same unit has the highest densities per square meter in plain sherds, decorated sherds, and burned clay/daub. Furthermore, the western area of the site, along with Unit 4, have the highest densities of sherds in the archeological deposits, ranging from 5.4-26.5 sherds per square meter (see Table 3), compared to only 0.1-3.6 sherds per square meter in Area B at the eastern end of the site (see Figure 2).

By depth, there is a stratigraphic division between the upper archeological deposits (0-40 to $50 \mathrm{~cm} \mathrm{bs)}$ and the lower archeological deposits (40 to $50-90 \mathrm{~cm} \mathrm{bs})$ in the character of the recovered prehistoric ceramic and lithic artifacts (Table 4). For example, while dart points are found throughout the archeological deposit—which suggests the movement and mixing of artifacts by bioturbation as well as slow aggradation of these alluvial deposits - they are concentrated from $40-90 \mathrm{~cm} \mathrm{bs}$; arrow points are concentrated from $0-30 \mathrm{~cm}$ bs.

Table 4. Prehistoric artifacts from the Hickory Creek \#2 site (HC-2) by depth, all units.

$\begin{array}{lllllllllll}\text { Depth DP } & \text { BIF } & \text { AP } & \text { FT } & \text { LD } & \text { FCR } & \text { GS } & \text { PS } & \text { DS } & \text { BC/D N }\end{array}$ (cm bs)

\begin{tabular}{llllllllllll}
\hline \multicolumn{1}{l}{ Suggested upper archeological deposits } \\
$0-10$ & - & 1 & 6 & - & 630 & - & - & $14 *$ & 6 & 1 & 658 \\
$10-20$ & 4 & 5 & 8 & 1 & 1299 & 1 & - & $47 *$ & 36 & 4 & 1405 \\
$20-30$ & 3 & 4 & 10 & 5 & 1451 & 2 & 1 & $60+$ & 48 & 19 & 1603 \\
$30-40$ & 1 & 4 & 2 & 2 & 1077 & 7 & 2 & $34 *$ & 19 & 14 & 1162 \\
$40-50$ & 11 & 6 & 2 & 2 & 1163 & 2 & - & $43 *$ & 14 & 11 & 1254
\end{tabular}


Table 4. Prehistoric artifacts from the Hickory Creek \#2 site (HC-2) by depth, all units, cont.

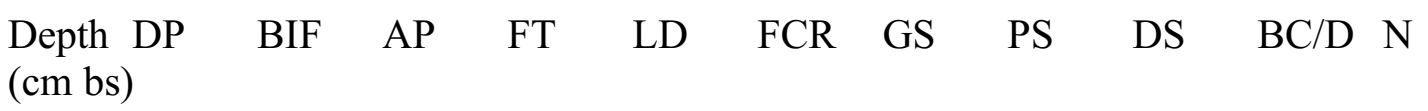

\begin{tabular}{llllllllllll}
\hline \multicolumn{1}{l}{ Suggested lower archeological deposits } \\
$50-60$ & 9 & 4 & 2 & 9 & 990 & 13 & 3 & 23 & 2 & 1 & 1056 \\
$60-70$ & 16 & 8 & - & 12 & 969 & 15 & 4 & 21 & 5 & - & 1050 \\
$70-80$ & 13 & 11 & - & 6 & 906 & 13 & 3 & 10 & 2 & 3 & 967 \\
$80-90$ & 6 & 3 & 1 & 1 & 554 & 9 & 4 & 1 & 6 & 2 & 587 \\
\hline
\end{tabular}

$\mathrm{DP}=$ dart point; $\mathrm{BIF}=$ biface; $\mathrm{AP}=$ arrow point; $\mathrm{FT}=$ flake tool; $\mathrm{LD}=$ lithic debris and cores; $\mathrm{GS}=$ ground stone tool; $\mathrm{PS}=$ plain sherd; $\mathrm{DS}=$ decorated sherd; $\mathrm{BC} / \mathrm{D}=$ burned clay $/$ daub *includes a plain pipe bowl; +includes two plain pipe sherds

Plain and decorated ceramic sherds are concentrated between 10-50 $\mathrm{cm}$ bs (where they comprise between 4.6-6.7\% of all the artifacts in those levels) at the Hickory Creek \#2 site (see Table 4). In the lowermost archeological deposits, sherds by level account for only $1.2-2.5 \%$ of the artifacts; in some measure, these are not Caddo sherds displaced from the upper archeological deposit, but Woodland period sherds (plain sandy paste Goose Creek Plain, var. unspecified sherds) from an earlier, and deeper, prehistoric occupation. Burned clay/daub is concentrated between $20-50 \mathrm{~cm}$ bs (see Table 4).

The temporal implications of the Unit artifact densities (see Table 3) and artifact category differences by depth (see Table 4) at the Hickory Creek \#2 site will be discussed in more detail in a later section of this report.

The single excavation unit at HC-3 contains a high density of artifacts: 303 artifacts per square meter (Table 5). This density is higher than all the hand-excavated units at the Hickory Creek \#2 site, except for Unit 4 (see Table 3). The density of artifacts by level is uniform between $0-60 \mathrm{~cm}$ bs (41-48 artifacts per level), and these same levels have all the dart points, other chipped stone tools, and ceramic sherds (Table 5). On this basis, we suggest that the archeological deposits from site HC-3 are likely the product of a single occupational component.

Table 5. Prehistoric artifacts from HC-3.

\begin{tabular}{llllllll}
\hline $\begin{array}{l}\text { Depth } \\
\text { (cm bs) }\end{array}$ & $\begin{array}{l}\text { Dart } \\
\text { Point }\end{array}$ & $\begin{array}{l}\text { Biface Flake } \\
\text { Tool }\end{array}$ & Tool & $\begin{array}{l}\text { Lithic } \\
\text { Debris }\end{array}$ & $\begin{array}{l}\text { Ground } \\
\text { stone tool }\end{array}$ & $\begin{array}{l}\text { Plain } \\
\text { sherd }\end{array}$ & N \\
\hline $0-10$ & - & - & 1 & 38 & - & 2 & 41 \\
$10-20$ & - & - & 2 & 41 & - & 2 & 45 \\
$20-30$ & 1 & - & - & 38 & - & 6 & 45 \\
$30-40$ & 2 & - & - & 39 & - & 1 & 42
\end{tabular}


Table 5. Prehistoric artifacts from HC-3, cont.

\begin{tabular}{|c|c|c|c|c|c|c|c|}
\hline $\begin{array}{l}\text { Depth } \\
\text { (cm bs) }\end{array}$ & $\begin{array}{l}\text { Dart } \\
\text { Point }\end{array}$ & $\begin{array}{l}\text { Biface } \\
\text { Tool }\end{array}$ & $\begin{array}{l}\text { Flake } \\
\text { Tool }\end{array}$ & $\begin{array}{l}\text { Lithic } \\
\text { Debris }\end{array}$ & $\begin{array}{l}\text { Ground } \\
\text { stone tool }\end{array}$ & $\begin{array}{l}\text { Plain } \\
\text { sherd }\end{array}$ & $\mathrm{N}$ \\
\hline $40-50$ & 2 & 1 & - & 43 & - & 1 & 47 \\
\hline $50-60$ & - & - & 1 & 46 & 1 & - & 48 \\
\hline $60-70$ & - & - & - & 29 & 1 & - & 30 \\
\hline Misc.* & - & - & 1 & 3 & - & 1 & 5 \\
\hline Totals & 5 & 1 & 5 & 277 & 2 & 13 & 303 \\
\hline
\end{tabular}

*from the unit wall and Hole 2

\section{Ceramic Sherds}

\section{HC 1}

There are two sherds in the PIT collections from HC-1. The first is a Goose Creek Plain, var. unspecified sandy paste rim sherd (Unit 1, back dirt). Goose Creek Plain is a diagnostic Woodland period, Mossy Grove (cf. Story 1990), material culture item in this part of the Neches River basin. The second sherd is a decorated body sherd from Unit 2 $(10-20 \mathrm{~cm} \mathrm{bs})$. The sherd, from a tempered prehistoric Caddo utility ware vessel of the Kiam Incised type (Suhm and Jelks 1962:Plate 45c, e), has horizontal incised lines on the lower rim and tool punctates covering the body of the vessel (Figure 3).

\section{Hickory Creek Site \#2 (HC-2)}

About $16.6 \%$ of the ceramic sherds analyzed from the Hickory Creek \#2 site have no temper, only a dense sandy paste. This includes four plain rims, including one with a suspension hole (Figure 4c, e-g), a lip notched rim, 49 plain body sherds, and three decorated sandy paste body sherds (Figure 4a). The decorated body sherds include one with widely-spaced parallel incised lines, a second sherd with closely-spaced parallel incised lines (Figure 4a), and the third is a sherd with sets of opposed incised lines (see Figure 6e, below); a similar decorated sandy paste sherd was found in the Woodland period component at the Hargrove Lake site (41HO150), about $12 \mathrm{~km}$ to the north along the Neches River (Jurney 2000:Figure 21a). Lip notched rims are a distinctive feature of Mossy Grove ceramics in East Texas sites, and at Lake Naconiche, these rims were found at the Naconiche Creek (41NA236) and Boyette (41NA285) sites in contexts that date from cal 2230-1830 B.P. (280 B.C. to A.D. 120), suggesting they are an horizon marker for the early part of the Woodland period (Perttula 2008:433). This in turn suggests that the Woodland period occupation at the Hickory Creek site began around 2200 years ago. 


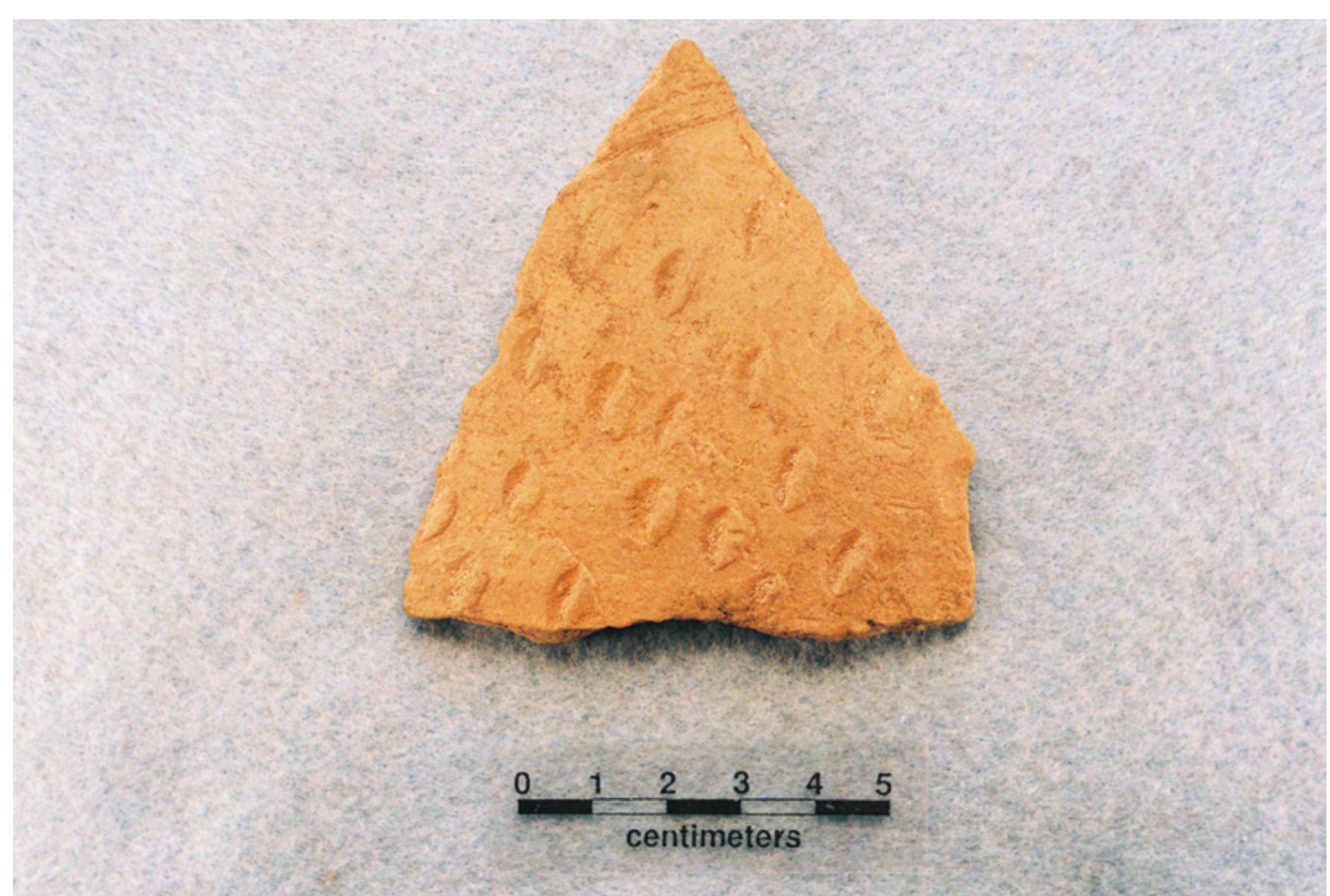

Figure 3. Kiam Incised body sherd from HC-1, Unit 2, 10-20 cm bs.

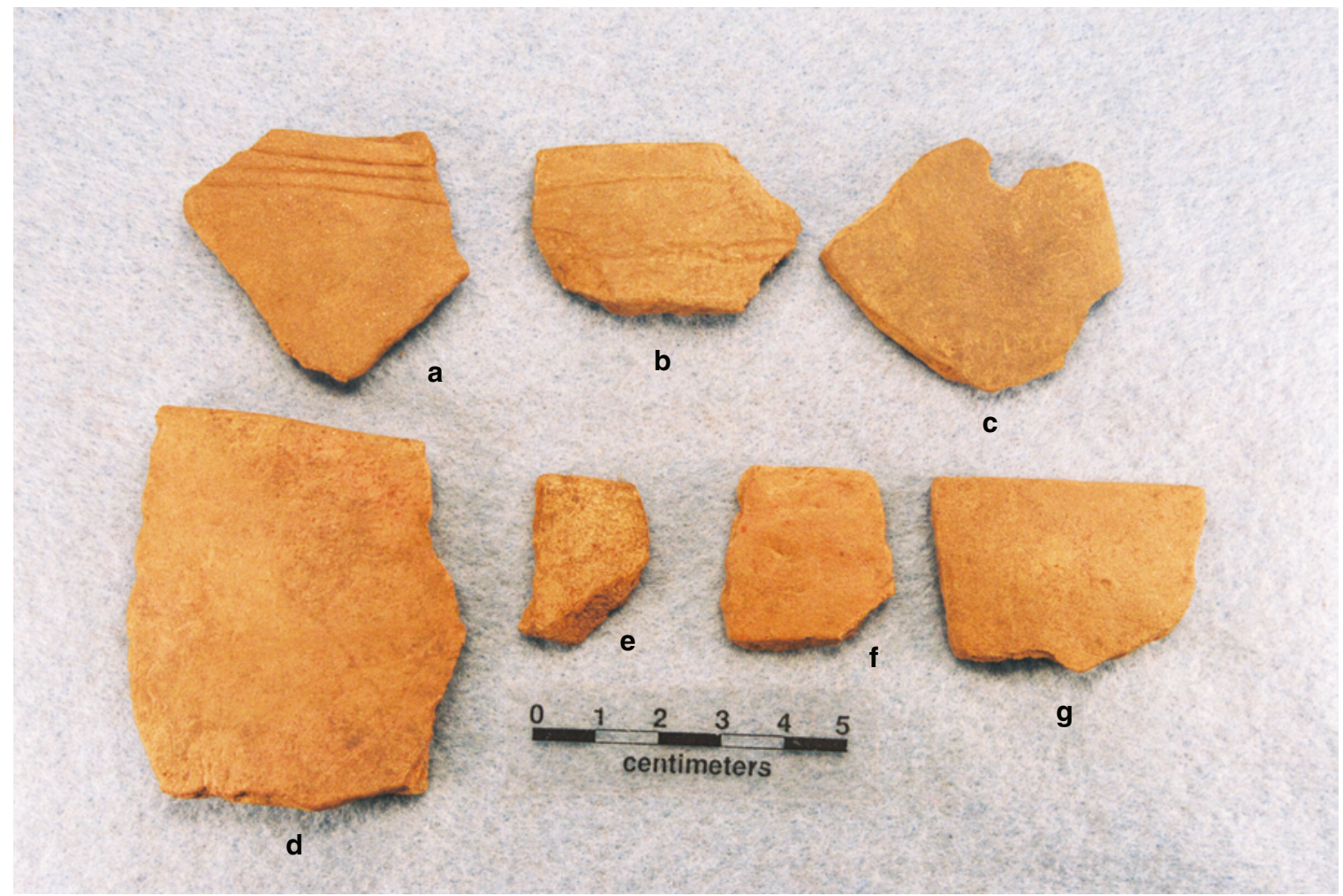

Figure 4. Sandy paste Goose Creek Plain sherds and tempered-sandy paste plain rim sherds: a, parallel incised sandy paste; $b$, horizontal incised, grog-tempered sandy paste; c, e-g, Goose Creek Plain rim sherds; d, plain hematite-tempered sandy paste rim. Provenience: a, Unit 5, 30-40 cm bs; b, Unit 3, 30-40 cm bs; c, Unit 6, 60- 
$70 \mathrm{~cm}$ bs; d, Unit 3, 40-50 cm bs; e, Pothole 8; f, Unit 1, 60-70 cm bs; g, Unit 4A, 10$20 \mathrm{~cm}$ bs.

These sandy paste sherds are from Woodland period Goose Creek Plain, var. unspecified vessels. Sandy paste Goose Creek Plain pottery is some of the earliest pottery made and used by Native Americans in East Texas, especially south and west of the Sabine River. The earliest pottery in these regions-Tchefuncte pottery-may date as early as 2500 years ago, if not earlier (see Webb et al. 1969). Saunders and Hays (2004:16) report that Tchefuncte pottery from Louisiana has been dated as early as $2800-3400$ years B.P.

At the Hickory Creek \#2 site, the sandy paste pottery sherds are primarily from the deeper Woodland and Late Archaic archeological deposits (i.e., deposits where Woodland and Late Archaic projectile points are concentrated, see below) in both Area A and B. In Area A, only $20 \%$ are found from $0-40 \mathrm{~cm}$ bs, and most of these are from Unit 4 at the southern end of the site (see Figure 2). The remaining $80 \%$ of the sandy paste sherds occur from $40-90 \mathrm{~cm}$ bs, with the highest densities from $60-70 \mathrm{~cm}$ bs. Only $12.5 \%$ of the sandy paste sherds in Area B were recovered from 0-40 cm, and the remainder $(87.5 \%)$ came from $40-70 \mathrm{~cm}$ bs. The highest density of sandy paste sherds in Area B is also between 60$70 \mathrm{~cm}$ bs.

Story (1990:275) had suggested some years ago that the earliest sandy paste ceramics in the Conroe-Livingston area dated from ca. 100 B.C. to A.D. 900; she termed this the Early Ceramic period of the Mossy Grove culture in inland Southeast Texas. More recent dating of archeological components with Goose Creek Plain sandy paste pottery indicates that this distinctive plain ware was made beginning about and after 2500 years ago. Table 6 lists a range of these dated sites - some Mossy Grove, but not all (e.g., Rogers et al. 2001) — and includes sites from inland Southeast Texas and the Louisiana coast to the Sabine River basin in East Texas. The most thoroughly documented (although undated) Woodland period ceramic assemblage in the East Texas region is from the Deshazo site (Fields 1995). This site is in the Bayou Loco drainage basin in the southwestern part of Nacogdoches County, Texas. Other well-described Woodland period ceramics include several sites at Lake Sam Rayburn in the Angelina and Attoyac drainage basins in the southern and southeastern part of Nacogdoches and adjoining counties (Jelks 1965), and two sites at Lake Naconiche in the Attoyac basin (Perttula 2008).

These dated sites range as late as ca. A.D. 900 in age, as previously indicated by Story (1990). It is possible to refine the ending date for the Woodland period to ca. A.D. 700 or 1250 years B.P. by excluding sites that have early arrow points (ca. A.D. 700-900 forms such as Steiner and Friley, see Shafer and Walters, in press) in addition to, or instead of, Gary and Kent dart points. The latter are apparently diagnostic of the Early Ceramic period (Story 1990:275) in Southeast Texas and perhaps the beginnings of the Formative Caddo period. Based on the Table 6 radiocarbon and OSL-dated summary of sites with Goose Creek Plain sherds and the presumed timing in the adoption of arrow points, then, the Mossy Grove sandy paste ceramic assemblage from the Hickory Creek \#2 site could date anywhere from ca. 2470-1250 years ago, or encompass the entirety of this period (as seems likely based on the range in stem width and thickness of the Gary dart points found there). 
Table 6. Dated sites in eastern Texas and southwestern Louisiana with Goose Creek Plain ceramic sherds.

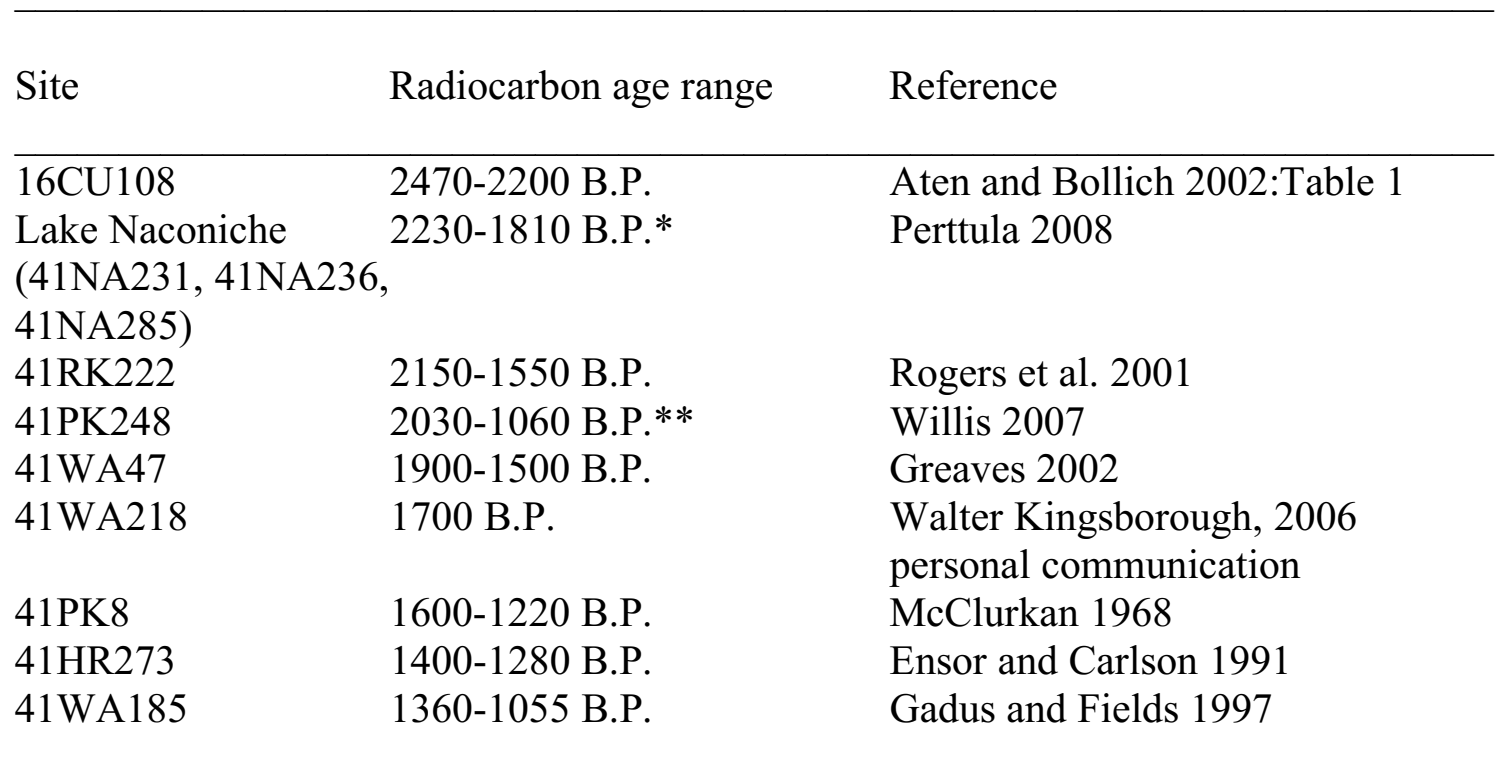

*Later calibrated dates between AD 670-877 from the Boyette site (41NA285) are also associated with sandy paste pottery, but possibly also associated with the adoption of tempered (and hence Caddo) wares.

**OSL dates

One sherd from Unit 3,10-20 cm bs, at the Hickory Creek \#2 site may be a Coles Creek Incised, var. Hardy body sherd (Brown 1998; Phillips 1970). This sherd has a series of horizontal incised lines - not overhanging - with a single row of small impressed triangles below the bottom incised line (see Figure 6c, below). According to Brown (1998:52), Coles Creek Incised, var. Hardy was manufactured in the lower Mississippi Valley between ca. A.D. 1000-1200, contemporaneous with the Early Caddo period in East Texas.

The remainder of the ceramic sherds from the Hickory Creek \#2 site are from a prehistoric Caddo occupation that is concentrated in Area A of the site, especially in Unit 3 (see Figure 2). There are a few decorated fine ware and utility ware and plain Caddo sherds in Units 1-2 and 4 in Area A and in Unit 6 in Area B, but their numbers are dwarfed by those from Unit 3. For example, of the 25 fine ware sherds from the site, $64 \%$ are from Unit 3, compared to $12 \%$ in Unit 1 and 6, respectively, $8 \%$ in Unit 2, and 4\% in Looter Hole 8 . Approximately $73 \%$ of the utility ware sherds from the Hickory Creek \#2 site were recovered in Unit 3, followed by other units in Area A: 10\% in Unit 1, 9\% in Unit $2,6.3 \%$ in Unit 4 ; only $1.8 \%$ of the utility ware sherds came from Unit 6 . Four other utility ware sherds were found in looter hole back dirt.

In Unit 3, the utility wares and fine wares are found between $0-50 \mathrm{~cm}$ bs, with peaks between $10-20 \mathrm{~cm}$ bs $(28 \%)$ and $20-30 \mathrm{~cm}$ bs (44\%) for the utility wares; the fine wares are concentrated between $20-30 \mathrm{~cm}$ bs (38\%). Although far fewer in numbers, the Caddo utility ware and fine ware sherds from the other units also occur at these depths, 
with three exceptions. There are several utility ware and fine ware sherds that were recovered between $60-90 \mathrm{~cm}$ bs in Units 1,2, and 4; without information on their context, it is suspected that these sherds were moved either by bioturbation or previous looting activities, although it is possible that these sherds were in pit or post hole features that were not recognized during the NFGT excavations.

\section{Utility Wares}

The utility ware sherds from the Hickory Creek \#2 site are dominated by brushed jars, probably of the Bullard Brushed type or an unnamed brushed predecessor. Approximately $67 \%$ of the utility wares have brushed decorations, either as the sole decoration, or in combination with roughened, punctated, incised, or grooved elements, including $40 \%$ of the rims (Table 7 ).

Table 7. Decorated utility ware sherds from the Hickory Creek \#2 site.

\begin{tabular}{llll} 
Decorative Method & Rim & Body & Percentage \\
\hline Brushed & 4 & 63 & 58.3 \\
Roughened-Brushed & - & 1 & 0.9 \\
Brushed-Punctated & - & 6 & 5.2 \\
Brushed-Incised & - & 2 & 1.7 \\
Brushed-Grooved & - & 1 & 0.9 \\
Incised-Punctated & 1 & 8 & 7.8 \\
Incised & 4 & 13 & 14.8 \\
Punctated & 1 & 9 & 8.7 \\
Pinched & - & 2 & 1.7 \\
& & & \\
Totals & 10 & 105 & \\
\hline
\end{tabular}

Each of the four rims has horizontal brushing marks (Figure 5a-b). In most cases, however, it is suspected that these brushed sherds are from vessels with horizontal brushed rims and vertical brushed bodies (Figures $6 \mathrm{~b}$ and $8 \mathrm{a}$ ), but the orientation of most of the body sherds is such that they are categorized as parallel brushed (Figure 7a-d). These sherds are probably from Bullard Brushed jars. One sherd has overlapping brushing on the body, and a brushed-punctated sherd has a diagonal brushed body (Figure $6 \mathrm{~g}$ ) below a horizontal row of tool punctates. 


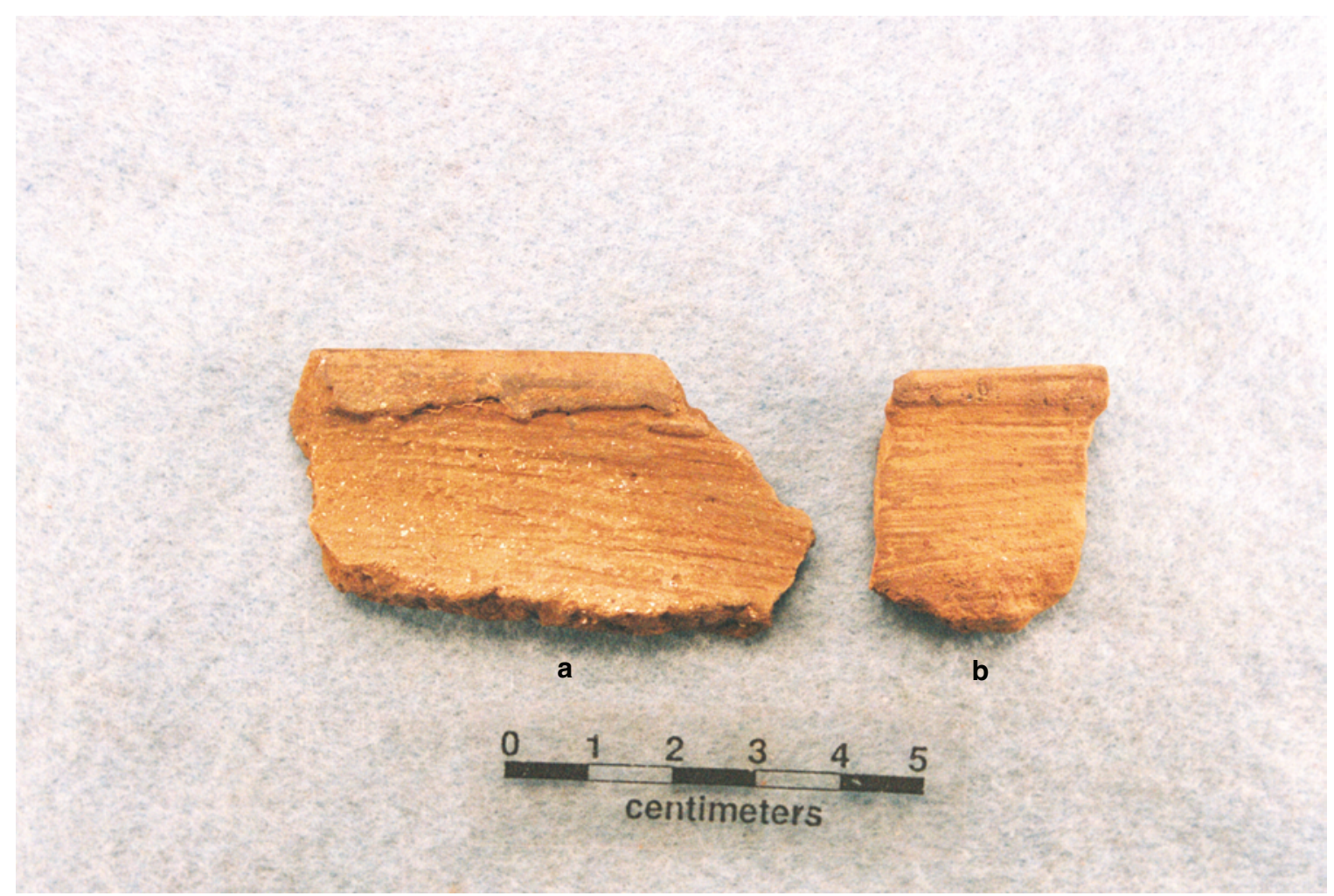

Figure 5. Horizontal brushed rim sherds from the Hickory Creek \#2 site. Provenience: a, Unit 3, 10-20 cm bs; b, Unit 2, 50-60 cm bs. 


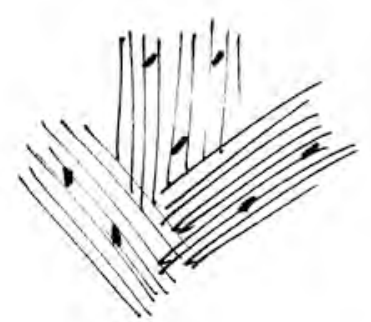

a
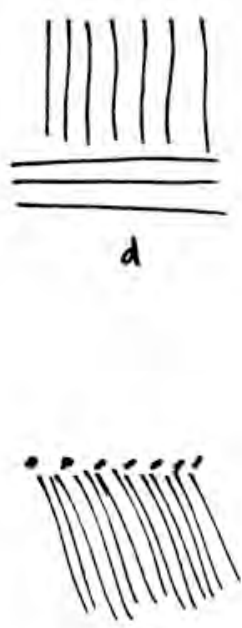

9

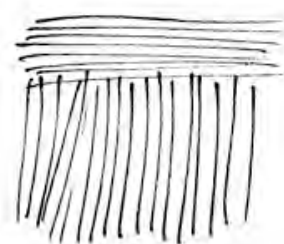

b
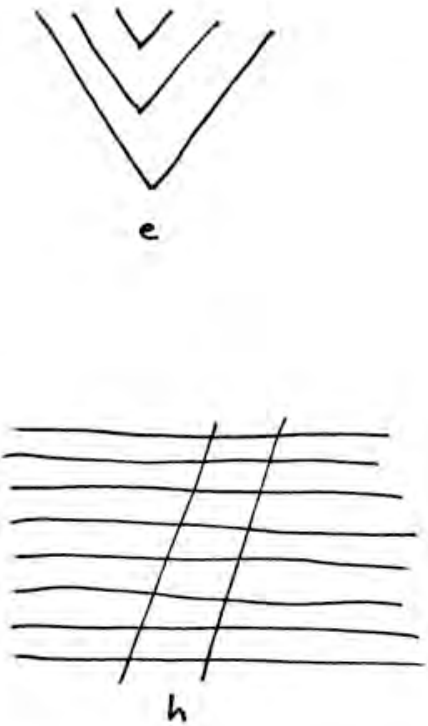

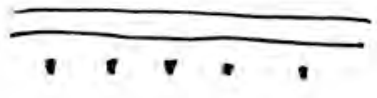

c

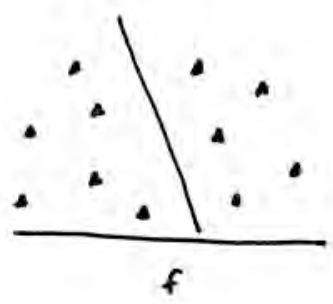

Figure 6. Selected decorative elements in the Hickory Creek \#2 site utility wares: a, g, brushed-punctated; b, brushed; c, Coles Creek Incised, var. Hardy; d-e, h, incised; f, incised-punctated. Provenience: a, Unit 3, 0-10 cm bs; b-c, Unit 3, 10-20 cm bs; d, Unit 3, 20-30 cm bs; e, Unit 6, 10-20 cm bs; f-g, Unit 3, 30-40 cm bs; h; Unit 3, 40-50 cm bs. 


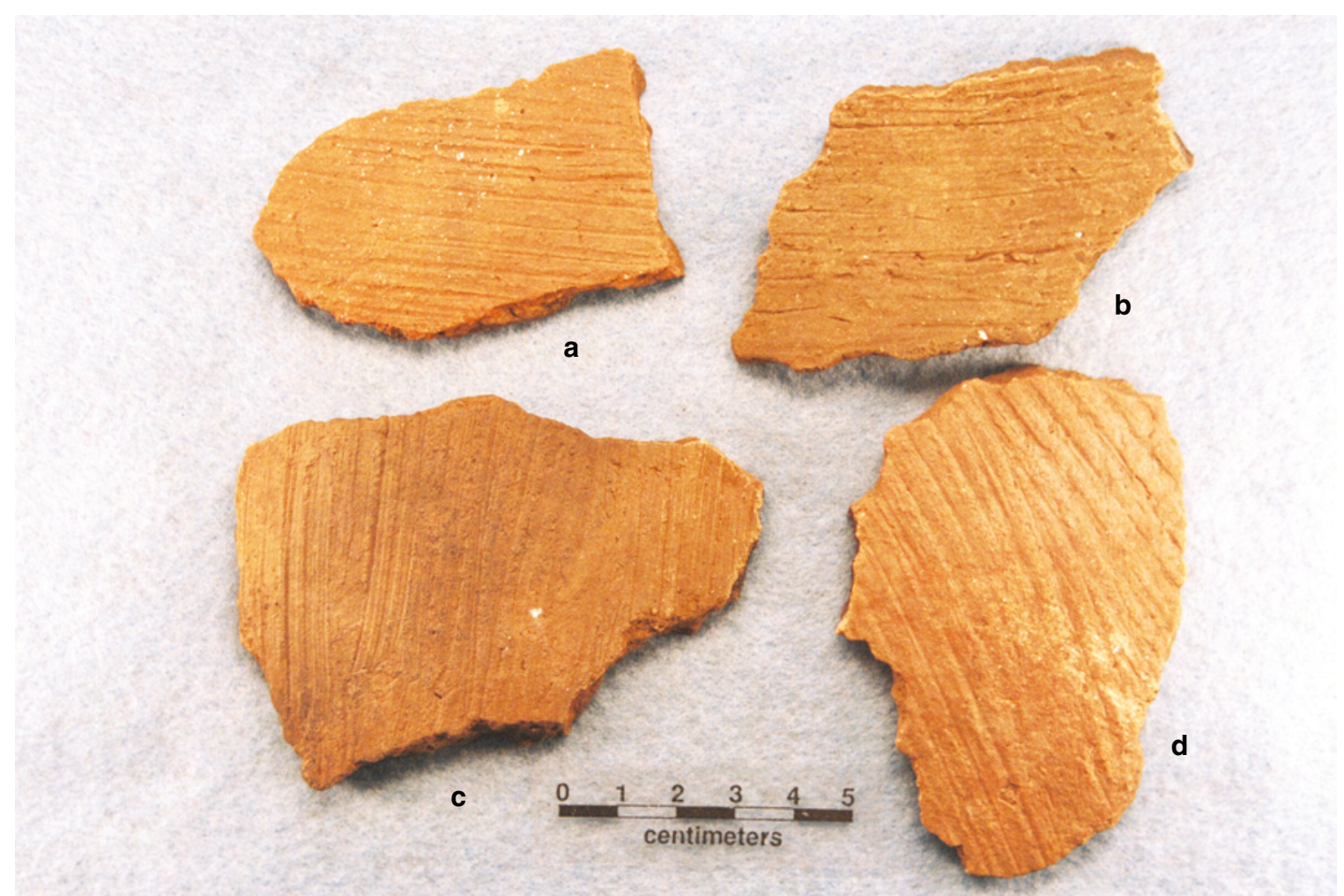

Figure 7. Parallel brushed body sherds from the Hickory Creek \#2 site. Provenience: a-d, Unit 3, 20-30 cm bs.

One lower rim-body sherd has a roughened rim area and vertical brushing on the vessel body (Figure 8c). Another lower rim-body sherd has a horizontal grooved zone on the rim and vertical brushing on the vessel body (Figure $8 \mathrm{~b}$ ). Grooved pottery (i.e., Lindsey Grooved) has been found at a number of Historic Allen phase sites in the Neches-Angelina River basin —including at the Deshazo site (41NA27, Fields 1995:199200 and Figure 75d-e) and Henry M. (41NA60, Perttula et al. 2009:Figure 12a-b)—but its appearance at the Hickory Creek \#2 site suggests that this distinctive utility ware may have first begun to be manufactured by Caddo potters well before the mid- $17^{\text {th }}$ century A.D. 


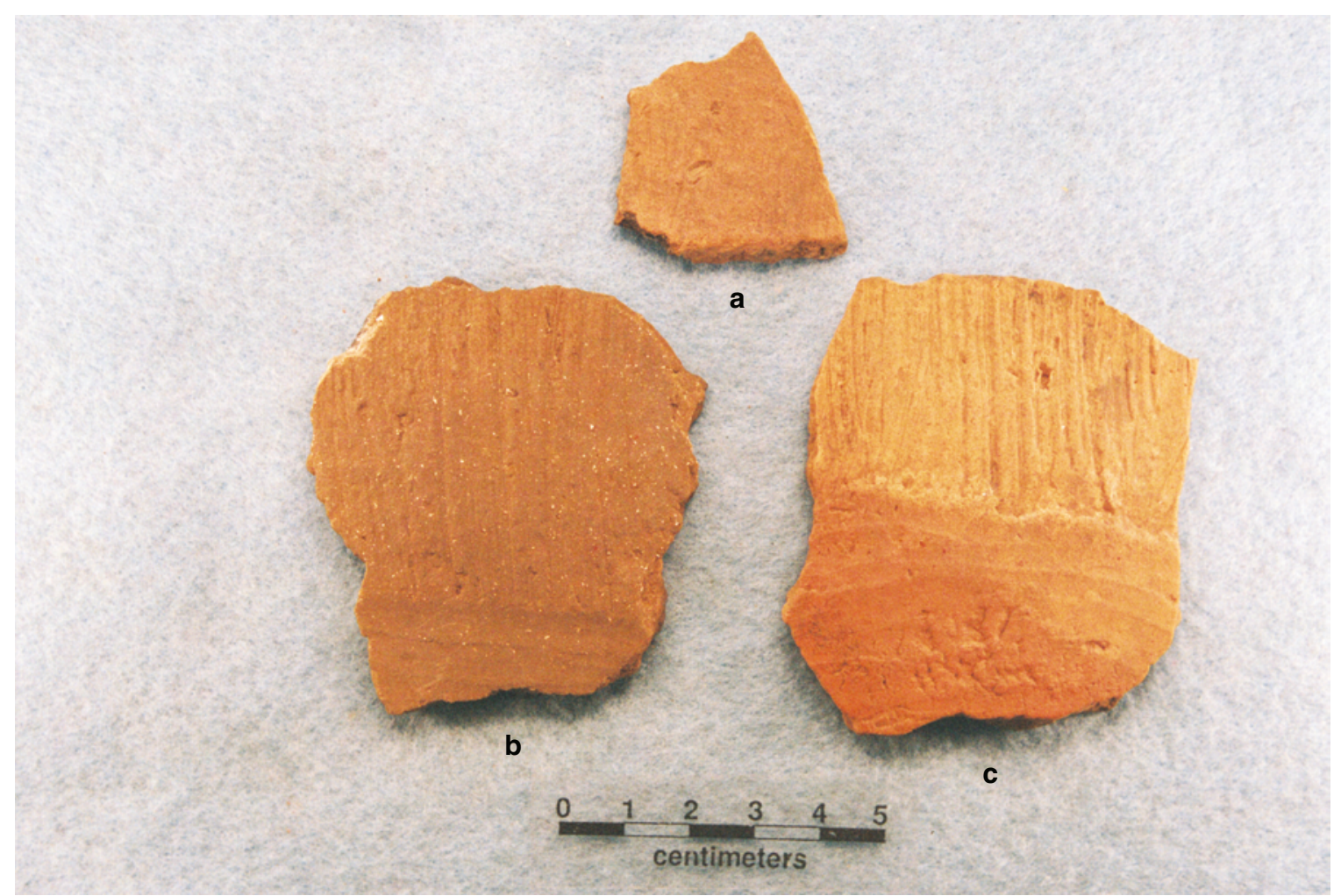

Figure 8. Sherds with vertical brushing from the Hickory Creek \#2 site: a, vertical brushed; b, vertical brushed and grooved; $c$, roughened rim and vertical brushed body. Provenience: a, Unit 3A, 10-20 cm bs; b, Unit 3, 20-30 cm bs; c, Unit 2, 10-20 cm bs.

A few of the brushed utility ware sherds also have punctated or incised elements interspersed with the brushing marks on vessel bodies (see Table 7). This includes three brushed-punctated body sherds where tool punctates have been pushed through the brushing (Figure 9b; see also Figure 6a), one sherd with a row of tool punctates at the rim-body junction and diagonal brushing on the body (see Figure 6g), and two others that have a row of tool punctations at the rim-body junction and vertical brushing on the vessel body. The brushed-incised sherds have closely-spaced parallel or horizontal brushed and incised lines, probably on the vessel body (Figure 9a, c). 


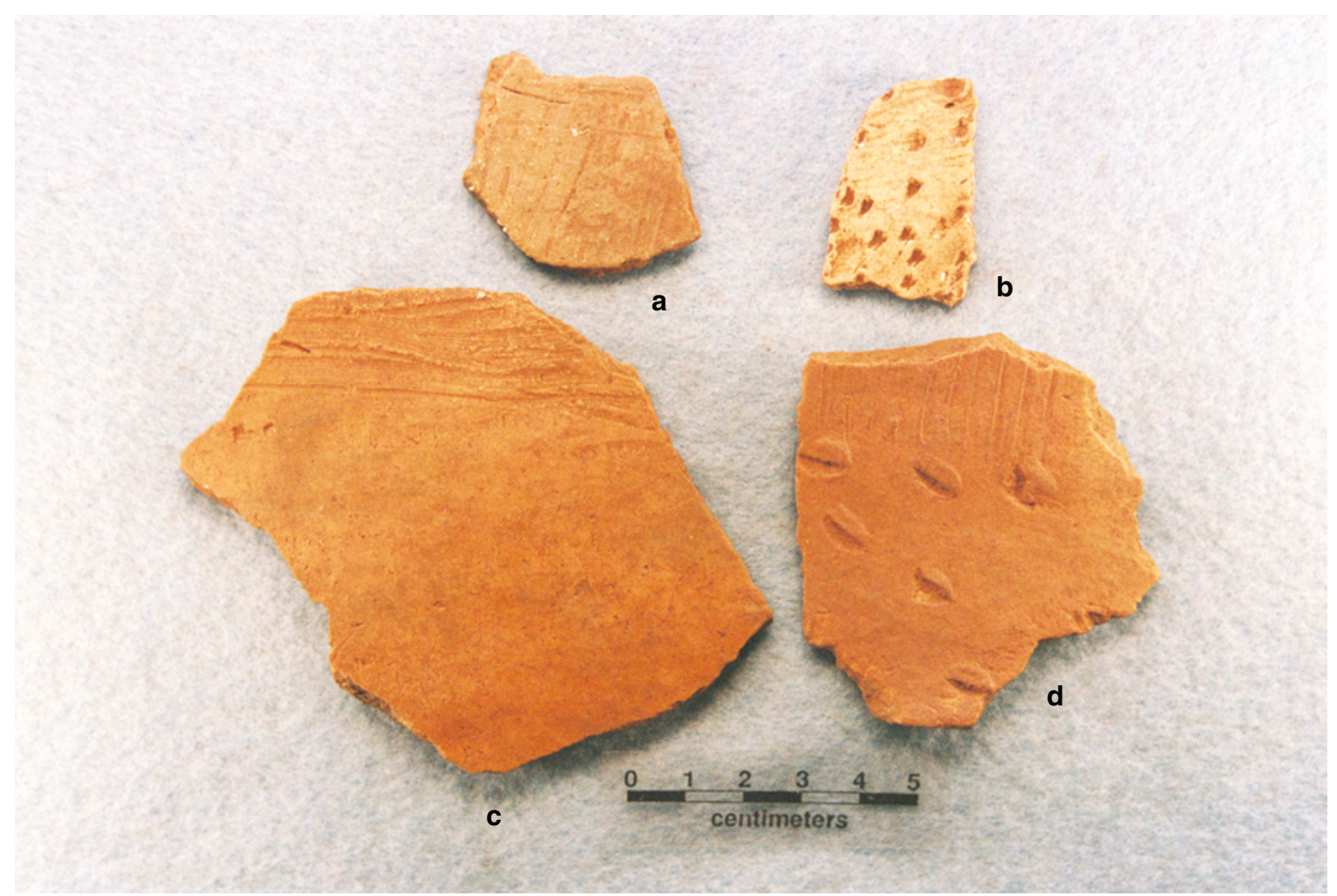

Figure 9. Brushed-incised and brushed-punctated sherds from the Hickory Creek \#2 site: a, c, brushed-incised; b, d, brushed-punctated. Provenience: a, c, Unit 3, 20$30 \mathrm{~cm}$ bs; b, Unit 4A, 70-80 cm bs; d, Unit 2, 0-10 cm bs.

Punctated rim and body sherds comprise $8.7 \%$ of the utility wares from the Hickory Creek \#2 site (see table 7). This includes rim and body sherds $(n=5)$ with rows of tool punctations (Figure 10a-e), two body sherds with random or freely placed tool or fingernail punctations (Figure 10f), and three body sherds with rows of circular punctations. 


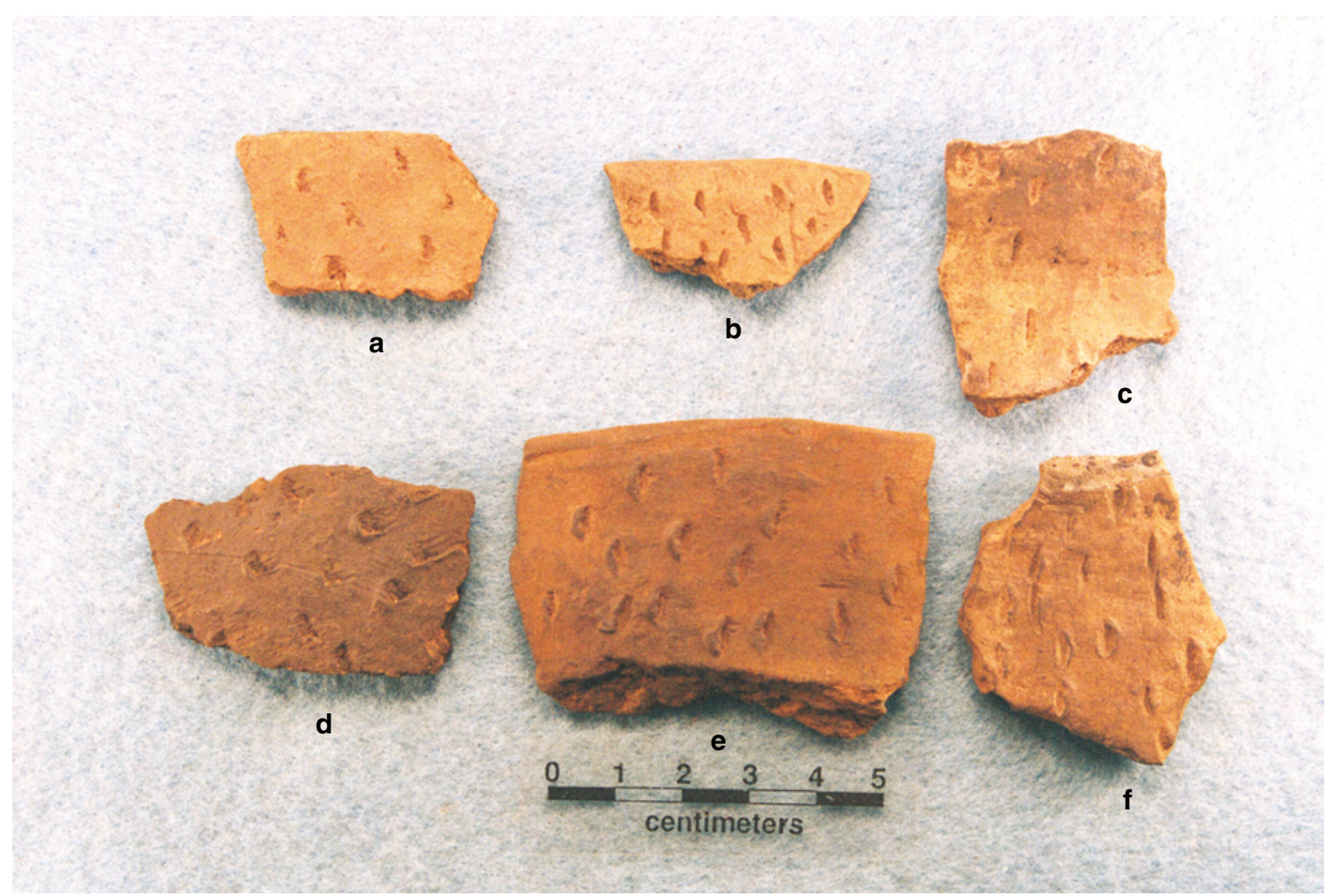

Figure 10. Punctated rim and body sherds from the Hickory Creek \#2 site.

Provenience: a, Unit 3, 30-40 cm bs; b, d, Unit 3, 20-30 cm bs; c, Unit 1, 20-30 cm bs; e, Unit 4, 10-20 cm bs; f, Unit 2, 20-30 cm bs.

Two body sherds have pinched rows (see Table 7). These rows of pinching likely covered both the rim and body of Killough Pinched jars (see Suhm and Jelks 1962:Plate 46).

The incised-punctated sherds are from vessels ( $\mathrm{n}=8$ sherds) with incised zones or panels filled with tool punctations (Figure 11b, f; see also Figure 6f) or are from vessels with a tool punctated rim and vertical incised lines on the vessel body ( $n=1$ sherd). In the case of the former incised-punctated sherds, the incised zones are rectangular, triangular (see Figure 6f), or circular, but in most cases the sherds are too small to identify the shape of the incised zones. 


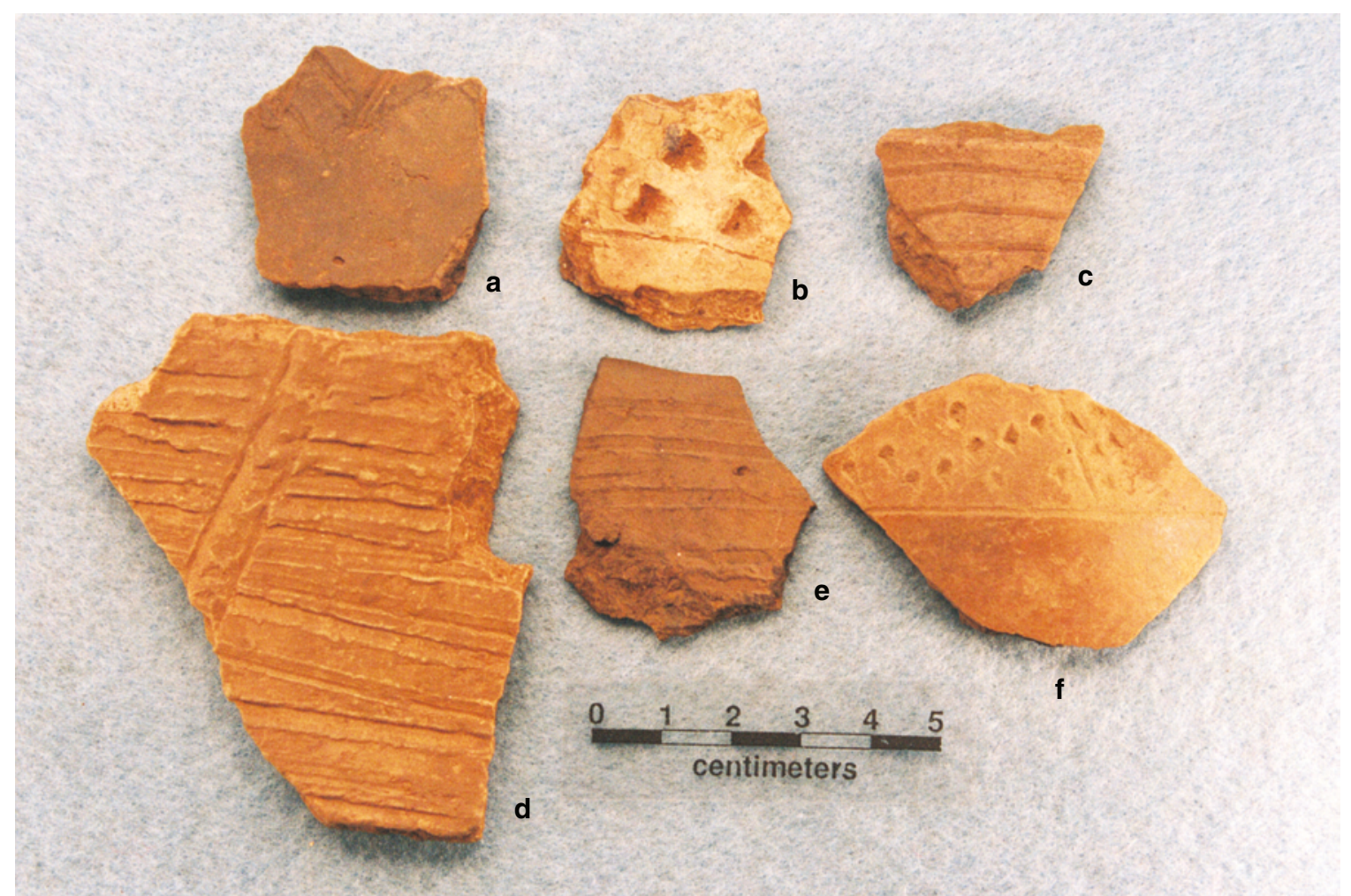

Figure 11. Incised and incised-punctated rim and body sherds from the Hickory Creek \#2 site: a, cross-hatched incised; $b$, $f$, incised-punctated; c-d, parallel incised lines; e, horizontal incised rim. Provenience: a, Pothole 8; b, Unit 4A, 80-90 cm bs; c, f Unit 3, 30-40 cm bs; d, Unit 3, 40-50 cm bs; e, Unit 3, 20-30 cm bs.

Incised vessels are an important part of the Hickory Creek \#2 utility ware assemblage, as they comprise $40 \%$ of the rims and $14.8 \%$ of all the utility ware sherds (see Table 7). The four incised rims have sets of horizontal incised lines encircling the upper part of the rim (see Figure 11e); in one case, a rim has a single incised line on the interior vessel surface. Body sherds have cross-hatched lines ( $n=2$, see Figure 11a), closely- to widely-spaced parallel lines ( $\mathrm{n}=5$, see Figure $11 \mathrm{c})$, parallel lines with overlapping incised lines $(\mathrm{n}=1$, see Figures $6 \mathrm{~h}$ and $11 \mathrm{~d})$, opposed lines $(\mathrm{n}=1$, see Figure $6 \mathrm{~d})$, a curvilinear line $(\mathrm{n}=1)$, and three sherds with a single straight incised line.

\section{Fine Wares}

The engraved fine ware sherds $(\mathrm{n}=25)$ from the Hickory Creek $\# 2$ site are primarily from several distinctive early decorated styles of Poynor Engraved carinated bowls (Table 8 ). Three (12\%) of the fine ware sherds are from engraved bottles. The remainder of the engraved sherds have relatively simple geometric decorative elements, but not enough of the vessels from whence they came are represented to define the motifs along either the rim panels of carinated bowls or the bodies of globular bottles. None of the engraved sherds from the Hickory Creek \#2 site are either red-slipped or have red or white clay pigments rubbed in the engraved lines. 
Table 8. Decorative elements on fine ware sherds from the Hickory Creek \#2 site.

Decorative element

$\operatorname{Rim}$

Body

$\mathrm{N}$

\section{Carinated bowls}

Poynor Engraved, var. Cook

Poynor Engraved, var. B (horizontal scroll)

Poynor Engraved, diagonal/hatched lines

$\begin{array}{lll}2 & - & 2 \\ 6 & 2 & 8 \\ 1 & 2 & 3\end{array}$

cross-hatched triangles and negative

triangular zone

horizontal-vertical-diagonal lines

parallel engraved lines

excised zone

single straight engraved line

$\begin{array}{lll}1 & - & 1 \\ - & 1 & 1 \\ - & 4 & 4 \\ - & 1 & 1 \\ - & 2 & 2\end{array}$

\section{Bottles}

opposed engraved lines

curvilinear engraved lines

$\begin{array}{lll}- & 1 & 1 \\ - & 2 & 2\end{array}$

Totals

10

15

25

There are eight rim and body sherds from a single vessel recovered in Unit 3 in Area A that are identified as Poynor Engraved, Var. B (Figures 12a-c, 13b, d, g, and 14ad). This vessel, a carinated bowl, has a series of horizontal and vertical interlocking scrolls on the rim panel, as well as sets of vertical or semi-circular lines that divide the scrolls on the panel and diagonal scroll filler elements. Var. B of Poynor Engraved has previously been recognized as an upper Neches River variety from only a few sites (the main reason it has not received a formal variety designation at this time) with early (ca. A.D. 1400-1480) Frankston phase mortuary contexts (Perttula 2009:Figure 6-64 and Table 6-37). The description of a few of the Poynor Engraved vessels (Vessels 15, 21, 23) from the Hargrove Lake site (Jurney 2000:64) may also be examples of Poynor Engraved, Var. B. vessels. 


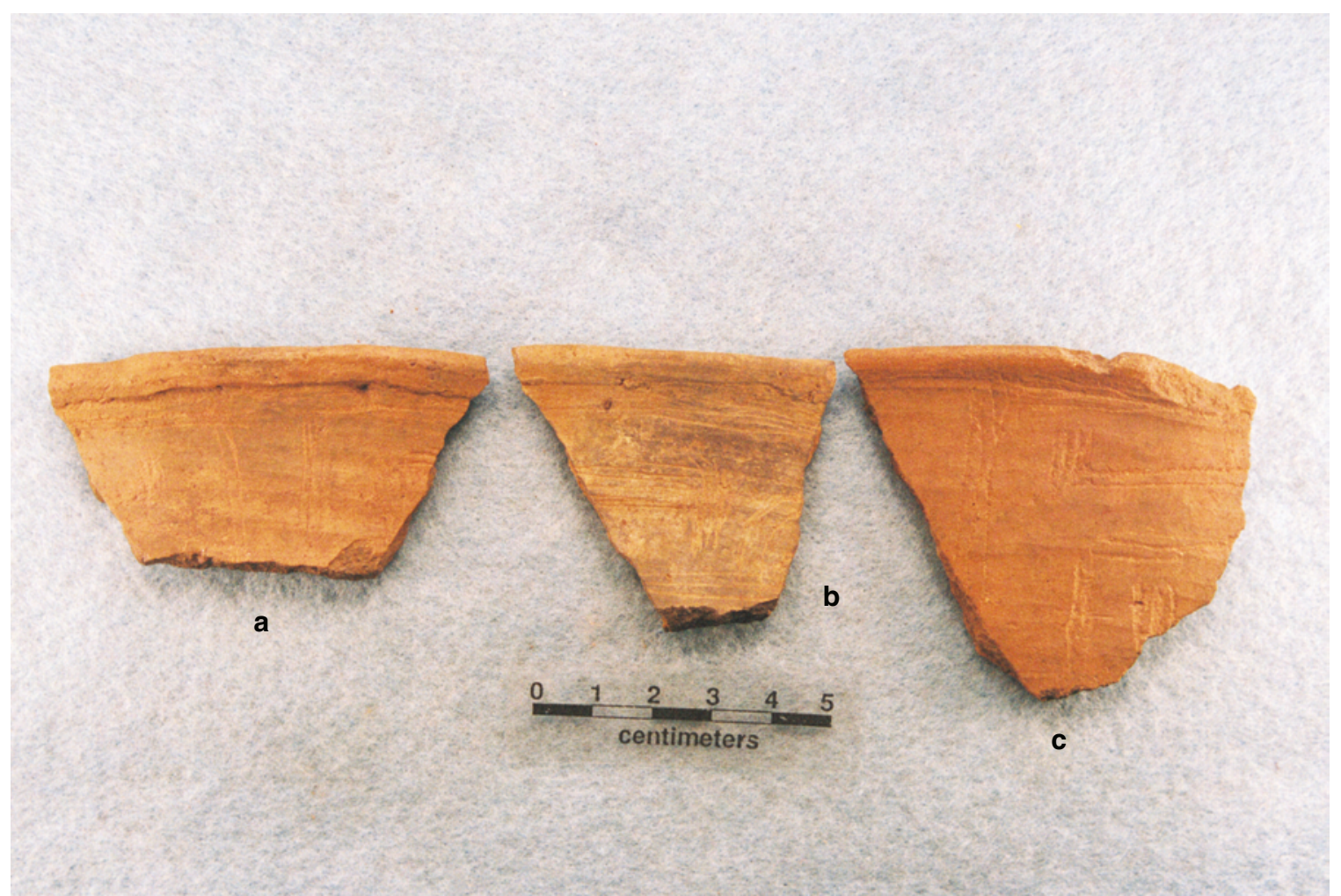

Figure 12. Rim sherds from a Poynor Engraved, var. $B$ vessel (carinated bowl) from the Hickory Creek \#2 site. Provenience: a, c, Unit 3, 20-30 cm bs; b, Unit 3, 30-40 cm bs. 


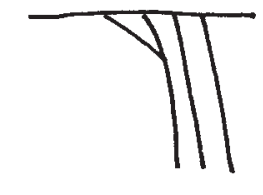

a
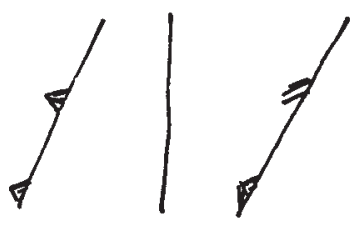

C

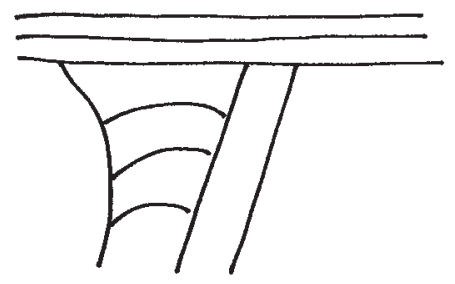

e

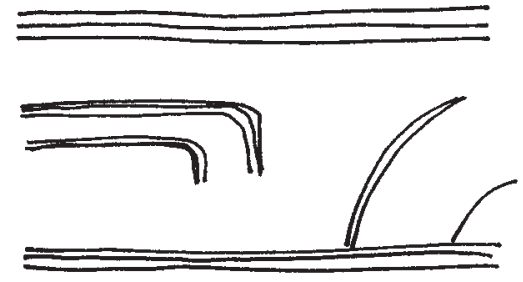

g

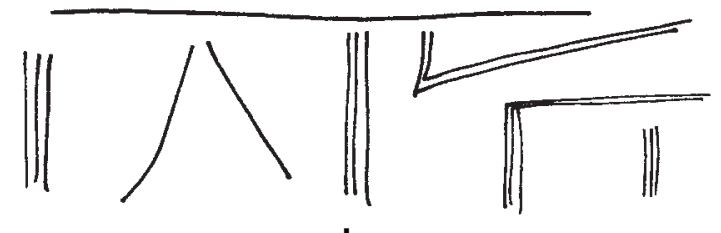

b
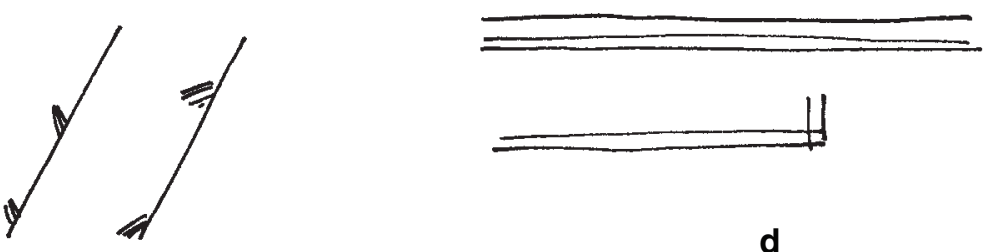

d
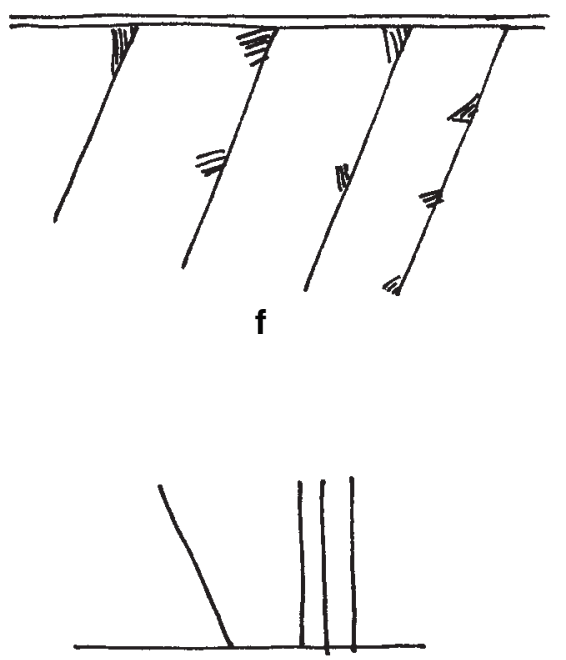

h

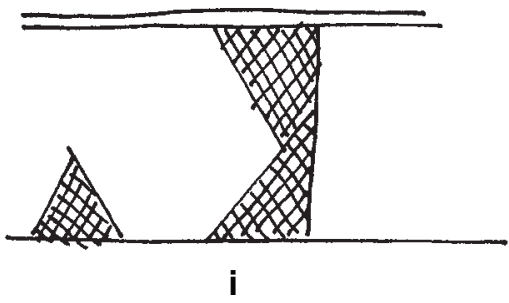

Figure 13. Selected engraved decorative elements in the Hickory Creek \#2 fine wares: a, Poynor Engraved, var. Cook; b, d, g, Poynor Engraved, var. B; c, f, diagonal engraved; e, cf. Poynor Engraved; $h$, opposed engraved lines; $i$, crosshatched and negative triangle zone. Provenience: a, Unit 2, 10-20 cm bs; b, e, Unit 3, 20-30 cm bs; c, Unit 6, 20-30 cm bs; d, Unit 3, 10-20 cm bs; f, Unit 6, 10-20 cm bs; g, Unit 3, 30-40 cm bs; h-i, Unit 3, 40-50 cm bs. 


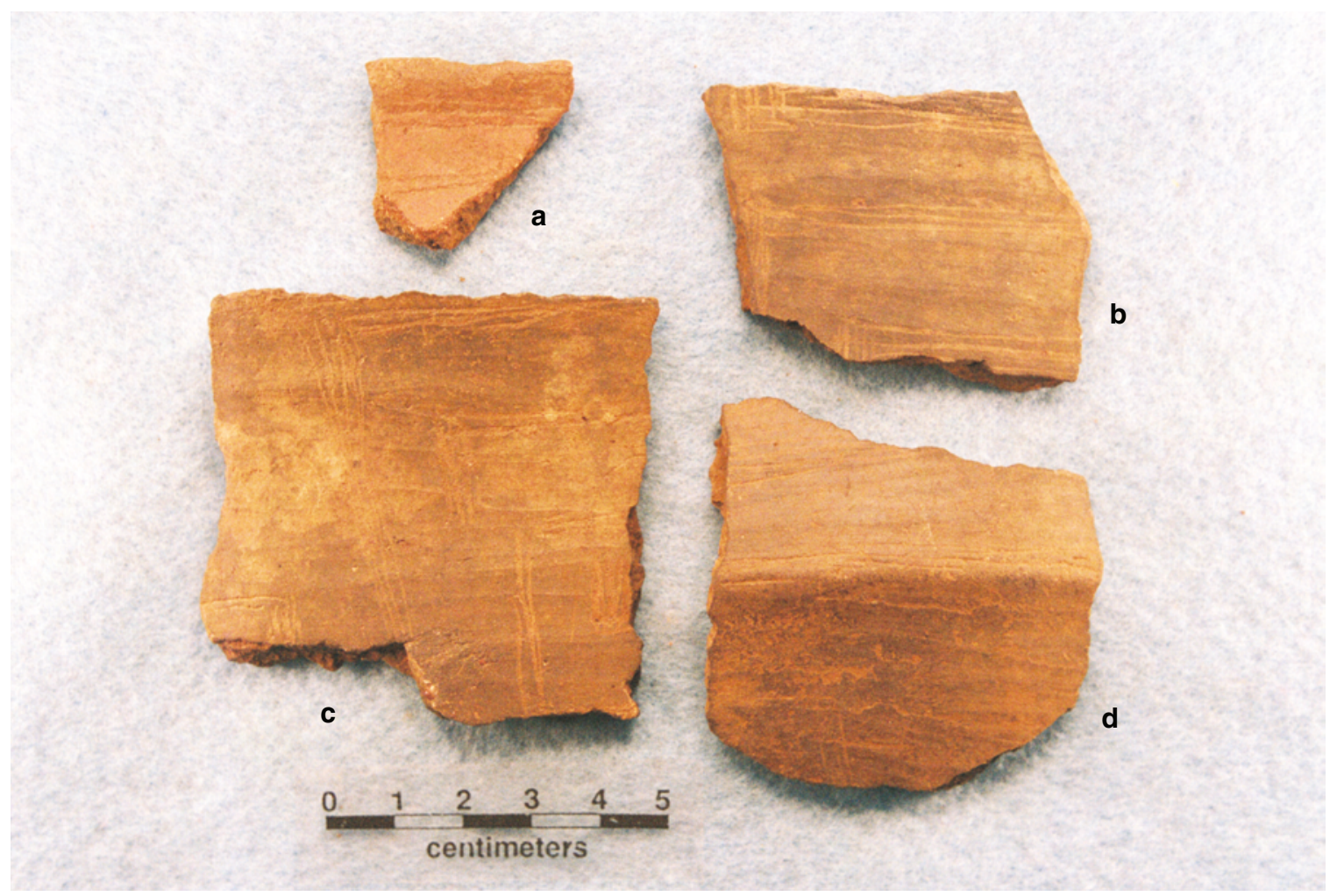

Figure 14. Rim and body sherds from a Poynor Engraved, var. $B$ carinated bowl at the Hickory Creek \#2 site. Provenience: a, d, Unit 3, 10-20 cm bs; b-c, Unit 3, 20-30 cm bs.

In Area B (Unit 6) are three sherds from another Poynor Engraved carinated bowl. This vessel has a continuous series of diagonal engraved lines on the rim panel, and most of the diagonal lines have small hatched pendant triangles (Figure 15a-b; see also Figure $13 \mathrm{c}, \mathrm{f})$. This vessel closely resembles another upper Neches River variety, Var. T, of Poynor Engraved, except that the Var. T vessels have small pendant triangles rather than hatched triangles on the diagonal engraved lines (Perttula 2009:Figure 6-64). This particular variety of Poynor Engraved is known from a ca. A.D. 1560-1650 mortuary context (Perttula 2009:Table 6-37). If this variety of Poynor Engraved has been correctly identified at the Hickory Creek \#2 site, it suggests that the Caddo occupation in Area postdates the Caddo occupation in Area A by at least 100-150 years. 


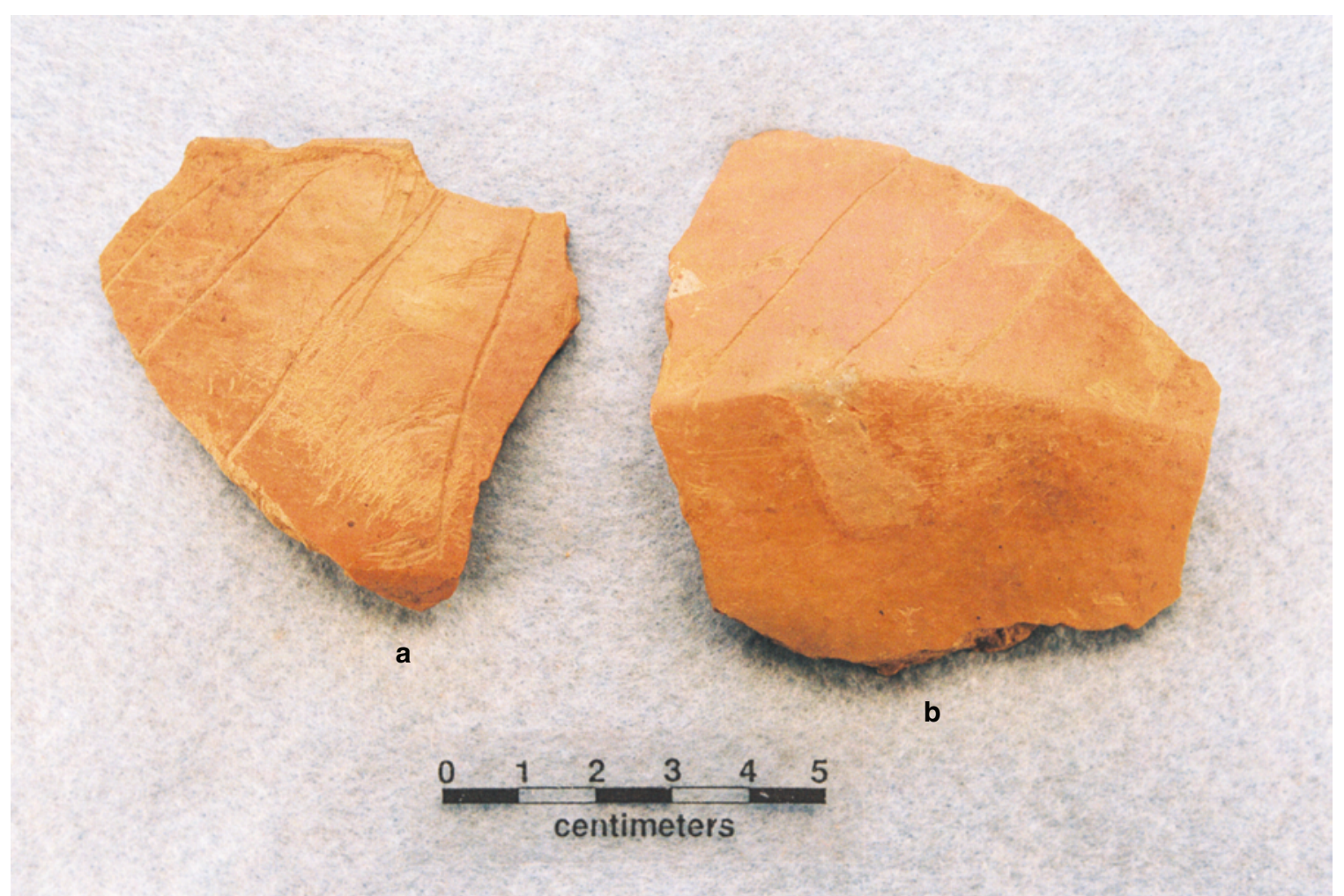

Figure 15. Diagonal engraved rim and body sherds from a carinated bowl found in Area B of the Hickory Creek \#2 site. Provenience: a, Unit 6, 10-20 cm bs; b, Unit 6, $20-30 \mathrm{~cm}$ bs.

Poynor Engraved, var. Cook is a recently defined upper Neches River engraved fine ware variety (Perttula 2008:Figure 1d). This variety has multiple sets of engraved ovals on the rim panel, occasionally with hatched areas at the upper and lower corners of each oval. There are two rims of Poynor Engraved, var. Cook from the Hickory Creek \#2 site (Figure 16b; see also Figure 13a, e), both from Area A. 


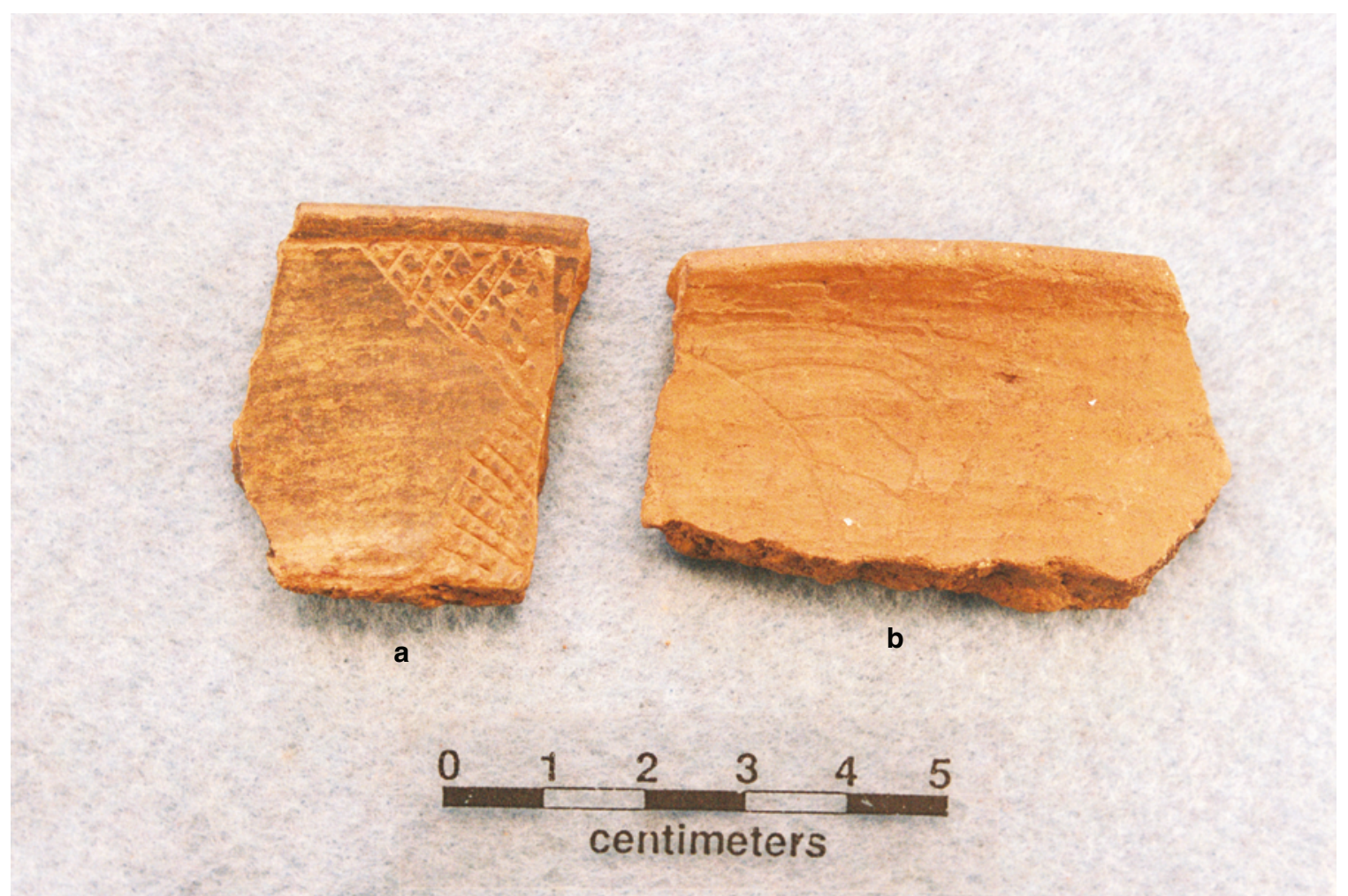

Figure 16. Other engraved rim sherds from the Hickory Creek \#2 site. Provenience: a, Unit 3, 40-50 cm bs; b, Unit 3, 20-30 cm bs.

There is one other distinctive engraved carinated bowl from the Hickory Creek \#2 site. This particular vessel, from Area A, has cross-hatched engraved triangles forming a negative triangular zone (see Figures 13i and 16a). Vessel 19 at the Hargrove Lake site has a triangular panel filled with cross-hatched engraved lines (Jurney 2000:64).

The remainder of the engraved sherds from the sherd fall into three groups. The first group is body sherds from carinated bowls $(\mathrm{n}=7)$ with simple geometric elements that have parallel, opposed, and straight lines in orientation. The second group consists of a single body sherd with a rectangular panel defined by sets of vertical engraved lines (see Figure 13h), reminiscent of Poynor Engraved, var. Blackburn (see Perttula 2008:Figure 1a). The third group includes three body sherds from bottles with either opposed $(n=1)$ or curvilinear $(n=2)$ engraved lines.

\section{Plain Wares}

The plain sherds include 21 rims (one with a lip tab), 186 body sherds, and 21 base sherds; there are also five plain sherdlets. The proportion of plain rims to decorated rims from fine ware and utility ware is $21: 20$, indicating that plain ware vessels are as common as decorated vessels in the Hickory Creek \#2 ceramic vessel assemblage. Plain ware vessels include bowls, carinated bowls, and jars. At the Hargrove Lake site (41HO150), Jurney (2000:57 and Tables 12 and 13) estimated that there were a minimum of 30 vessels represented in the 374 sherds recovered in the work. Only $13 \%$ of these vessels were thought to be plain at this site, but the actual number of plain rim, body, or 
base sherds from Hargrove Lake cannot be determined from the information provided in the report.

The plain to decorated sherd ratio (P/DR), a useful chronological measure in some instances in East Texas Caddo sherd assemblages (see Perttula 2004:390), is 1.63 (i.e., $38 \%$ of the tempered Caddo pottery sherds are decorated). This is consistent with other $13^{\text {th }}$ to mid- $15^{\text {th }}$ century Caddo assemblages in the Neches-Angelina and middle Sabine River basins. Post-A.D. 1450-1650 Caddo sherd assemblages in these areas typically have P/DR that range from 0.56-1.03. On Historic Caddo ceramic assemblages on San Pedro Creek, P/DR values range from a very low 0.31-0.32 (Perttula and Nelson 2006:62). ${ }^{4}$

\section{Use of Temper in the Caddo Ceramics from the Hickory Creek \#2 Site}

Of the sherds analyzed for temper use that are from prehistoric Caddo vessels, grog was the preferred aplastic in the Caddo wares (Table 9), followed by crushed and burned bone and crushed pieces of hematite. Approximately $16.8 \%$ of the tempered Caddo sherds have a sandy paste, indicating use of a natural sandy clay by Caddo potters.

Table 9. Temper choice in the ceramic sherds from the Hickory Creek \#2 site.

\begin{tabular}{lll} 
Temper-paste combinations & $\mathrm{N}$ & Percentage \\
\hline Grog & 138 & 41.0 \\
Grog-sandy paste & 33 & 9.8 \\
Grog-bone & 35 & 10.4 \\
Grog-bone-sandy paste & 1 & 0.3 \\
Grog-hematite & 17 & 5.0 \\
Grog-hematite-sandy paste & 8 & 2.4 \\
Grog-bone-hematite & 4 & 1.2 \\
Grog-organics & 2 & 0.6 \\
Grog-organics-bone & 1 & 0.3 \\
Grog-organics-sandy paste & 1 & 0.3 \\
Bone & 33 & 9.8 \\
Bone-hematite & 3 & 0.9 \\
Bone-hematite-sandy paste & 1 & 0.3 \\
Hematite & 1 & 0.3 \\
Hematite-sandy paste & 3 & 0.9 \\
Sandy paste* & 56 & 16.6
\end{tabular}


Table 9. Temper choice in the ceramic sherds from the Hickory Creek \#2 site, cont.
Temper-paste combinations
$\mathrm{N}$
Percentage

$\underline{\text { Summary for all sherds, sherds having the following tempers: }}$

$\begin{array}{lll}\text { Grog } & 240 & 71.2 \\ \text { Bone } & 78 & 23.1 \\ \text { Hematite } & 37 & 11.0 \\ \text { Organics } & 4 & 1.2 \\ \text { Sandy paste and at least one temper } & 47 & 14.0 \\ \text { Sandy paste and no temper* } & 56 & 16.6\end{array}$

Note: percentages in the summary tabulation amount to more than $100 \%$ because vessel sherds commonly have more than one temper, and/or also have a sandy paste

*Goose Creek Plain, var. unspecified, associated with Mossy Grove component

The proportions of tempers selected by Caddo potters at the Hickory Creek \#2 site are very similar to Caddo sites in the San Pedro Creek valley in the northern part of Houston County. There, at the Nabedache Blanco (41HO211) and Nabedache Azul (41HO214) sites, grog was the preferred temper choice, but sherds from vessels also tempered with bone or hematite comprised between 20.4-22.5\% for bone temper and 4.49.7\% for hematite temper (Perttula and Nelson 2006:Table 3 and Figure 37).

One of the technological distinctions noted in the Caddo pottery from the Neches River basin is in the relative importance of bone-tempered or grog-bone-tempered vessels. In the upper Neches River basin (see Perttula 2009:Figure 6-70), Caddo potters had a tradition of vessel manufacture primarily using grog temper; bone-tempered pottery typically comprises less than $5 \%$ of sherd assemblages. Farther downstream on the Neches (i.e., from San Pedro Creek) and east in the Angelina, Attoyac, and Sabine River drainages, contemporaneous ceramic complexes belonged to a different ceramic tradition where bone-tempered pottery vessels are much more common among all categories of vessels (i.e., fine wares, utility wares, and plain wares). The Caddo pottery from the Hickory Creek \#2 site appears to belong to this second Caddo ceramic tradition.

\section{HC-3}

The thirteen plain rim and body sherds from $\mathrm{HC}-3$ were recovered from $0-50 \mathrm{~cm}$ bs; the highest densities of sherds are between $0-30 \mathrm{~cm}$ bs. Eight of the sherds are from Woodland period, Mossy Grove, Goose Creek Plain, var. unspecified vessels (Figure 17). The other plain body sherds are from vessels tempered with grog-hematite $(\mathrm{n}=4)$ or grog $(\mathrm{n}=1)$; two of the grog-hematite-tempered sherds have a sandy paste. In this part of East Texas, the use of grog and/or hematite temper in the manufacture of vessels is thought to be associated with post-A.D. 850 Caddo pottery, but there is no evidence (i.e., decorated 
Caddo vessel sherds) of a prehistoric Caddo occupation, and the sandy paste and tempered sherds are found together in the archeological deposit. Combined with the recovery of Woodland style Kent dart points from the same depths as the pottery suggests that the principal use of ceramics at HC-3 took place during the Woodland period, probably the latter part of the period (after ca. A.D. 400).

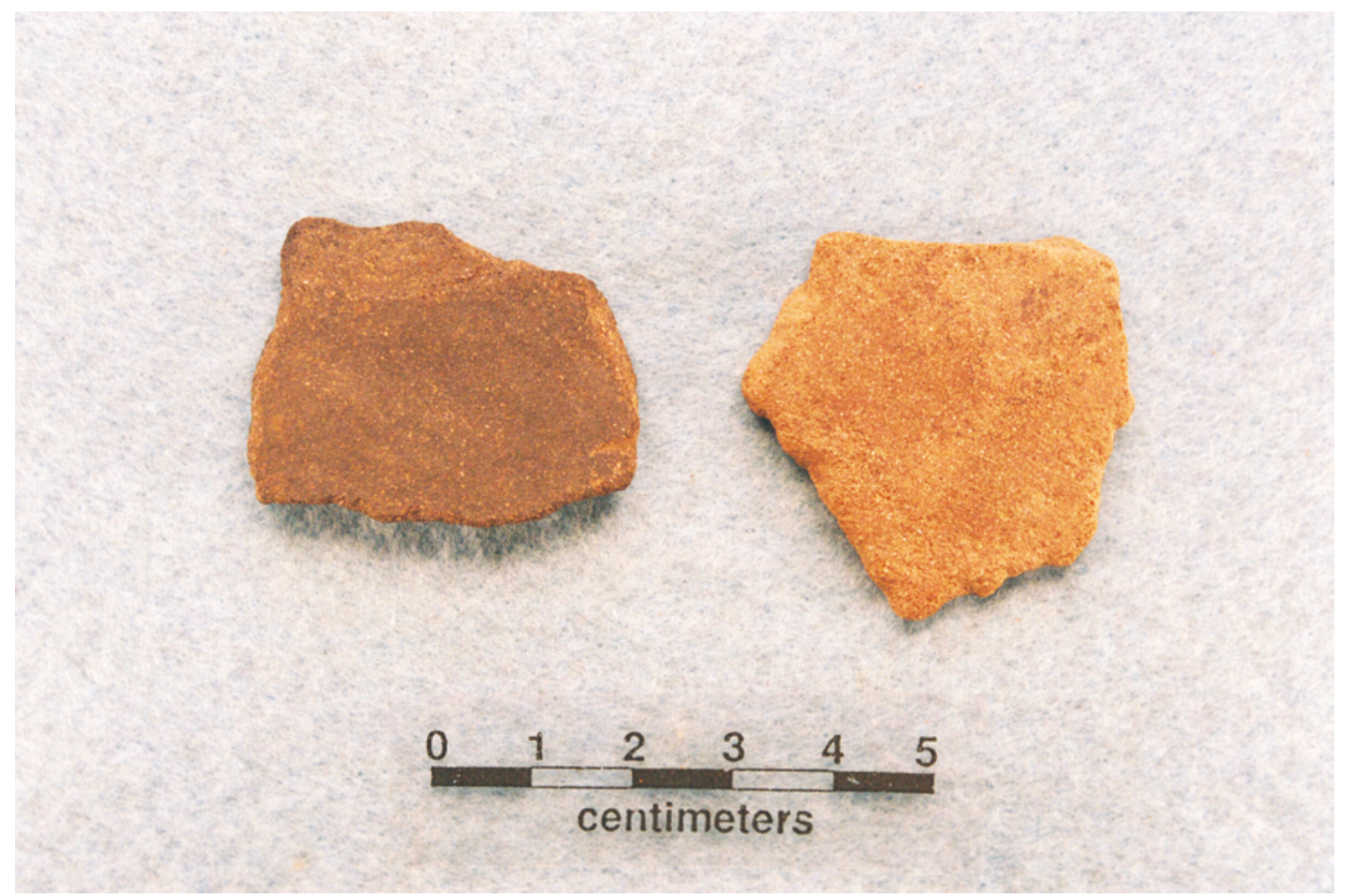

Figure 17. Goose Creek Plain body sherds from HC-3. Provenience, Unit 1, 20-30 cm bs.

\section{Pipe Sherds}

The six pipe sherds in the collection are from the Hickory Creek \#2 site (HC-2). Five are plain bowl (Figure 18a-b) and stem sherds from bone-tempered Red River style long-stemmed pipes, which were made by the Caddo from ca. A.D. 800 to the early $15^{\text {th }}$ century A.D (see Hoffman 1967). These five Red River pipe sherds are from 10-50 cm bs in Unit 3, the one area on the site with concentrated Caddo habitation deposits. 


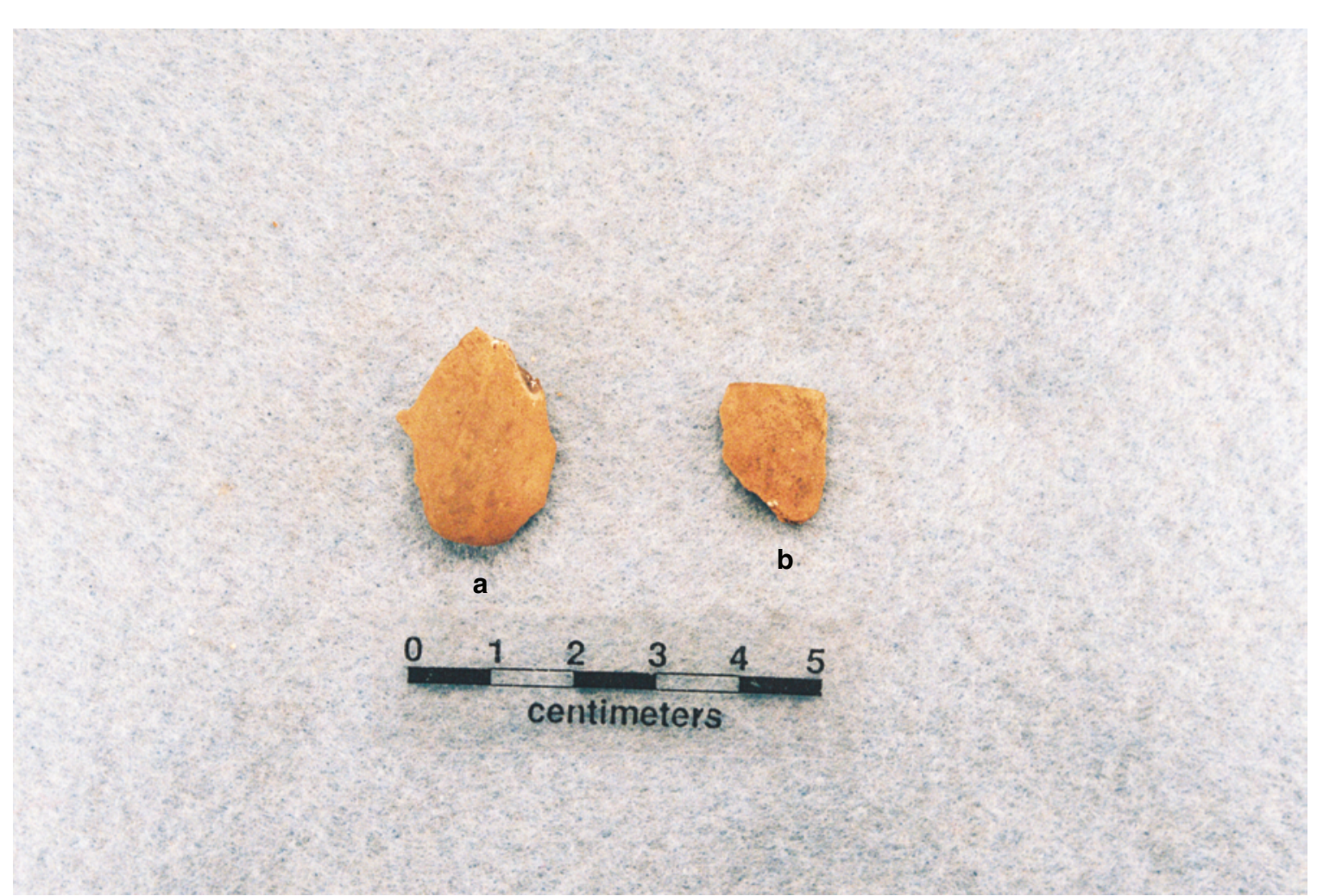

Figure 18. Plain pipe bowls from Red River long-stemmed pipes at the Hickory Creek \#2 site. Provenience: a, Unit 3, 20-30 cm bs; b, Unit 3, 30-40 cm bs.

The other pipe sherd is from Unit $6(0-10 \mathrm{~cm} \mathrm{bs})$ in Area B. It is the rim from a grog-bone-tempered elbow pipe bowl. The first use of clay elbow pipes in the Neches River basin began in the mid-14 ${ }^{\text {th }}$ century A.D. (Perttula 2009), and they became increasingly popular after that time, eventually replacing the long-stemmed Red River pipes. Many elbow pipes had engraved, punctated, or incised decorations on both the bowl and the stem, but the Hickory Creek \#2 pipe bowl appears to be plain.

\section{Burned Clay/Daub}

The pieces of burned clay and daub $(n=58)$ in the Hickory Creek site collections are from the Hickory Creek \#2 site (HC-2). These come primarily from the excavations in Unit 3 in the western part of the site (see Tables 2-3), as well as Unit 4, both in Area A (see Figure 2), and from the upper Caddo archeological deposits (see Table 4). The concentration of burned clay and daub in Unit 3 suggests that a thatch-and clay-covered Caddo structure may have stood in this area of the site that may have been burned down, preserving the impressions of thatch in the clay daub.

\section{Chipped Stone}

For the purposes of this analysis, chipped stone tools and lithic debris are divided into four distinct and primary lithic raw materials: chert, quartzite (fine to coarsegrained); Glover quartzite; and petrified wood; ferruginous sandstone is also represented among the chipped stone artifacts, along with quartz and Manning Fused Glass (see 
Brown 1976), but in very low amounts. The vast majority of the chert raw materials are high quality stone of gray, dark gray, brownish-gray, and/or black colors, occasionally with a limestone-covered cortex, and these materials are apparently from Central Texas Edwards Plateau sources; these materials are available also in Trinity River and Brazos River gravel sources no closer than about $50 \mathrm{~km}$ to the west of the Hickory Creek valley. Local cherts in gravel beds tend to be red, tan, and brown in color (Girard 1995:66). The quartzite and petrified wood raw materials are available as small cobbles and pebbles in local stream gravels along the Neches River. Glover quartzite is a distinctive coarsegrained quartzite that occurs in the Glover Sandstone Formation in this part of Houston County (Perttula and Nelson 2006:7, 84). This particular quartzite has a sugary coarsegrained texture and is light gray to yellowish-brown in color.

The chipped stone artifacts from the Hickory Creek sites were sorted into a number of morphological and/or functional classes, including tools (including dart points, arrow points, bifaces and bifacial preforms, and flake tools), lithic debris, and cores; the latter two (and most of the bifaces) being the by-product of tool manufacture. Each specimen within the various artifact classes were then separated by raw material, following the raw material categories discussed above.

\section{Dart points}

\section{Paleoindian Projectile Points}

We begin this section first with a discussion about the one Paleoindian point recovered in the PIT project from the Houston County sites. In several different compilations, Meltzer (1986), Meltzer and Bever (1995), and Bever and Meltzer (2007) have discussed the spatial distribution of Clovis points (dated to ca. 11,000 years B.P. or 13,000 cal years B.P.) across Texas, and explored various reasons why the Clovis archaeological record is structured the way it is. In their most recent summary, Bever and Meltzer (2007:Table 3) report that 74 Clovis points have been documented in East Texas, representing approximately $13.6 \%$ of the total number of Clovis points $(n=544)$ in the Texas Clovis Fluted Point Survey (TCFPS).

One of their findings is that the wooded East Texas region has the highest density of Clovis points per 10,000 $\mathrm{mi}^{2}$ (Bever and Meltzer 2007:Table 4 and Figure 2) in the state of Texas, as well as the highest density of Clovis sites (7.47 sites per 10,000 $\left.\mathrm{mi}^{2}\right)$ across the state (Bever and Meltzer 2007:Figure 3 and Table 5). Bever and Meltzer (2007:74, 91-92) note that this region of the state, like much of the Southeastern Woodlands of which it is a part, "has a rich Clovis record," one that may not have been left by "highly mobile hunter-foragers leaving behind an ephemeral archeological record," but by groups "engaged in the types of activities that left a structured, site-based archeological record." Nevertheless, because not a single Clovis site has been thoroughly excavated and studied in East Texas, the "understanding of Clovis lifeways in the east remains woefully underdeveloped" (Bever and Meltzer 2007:92).

We share the concern of Bever and Meltzer (2007:92) that a concerted effort is needed in East Texas to discover and excavate Clovis sites. We are optimistic that 
contextually intact Clovis sites will be discovered and studied by professional archeologists, most likely in the Sulphur, Big Cypress, or Sabine River drainage basins (see Bever and Meltzer 2007:Figure 1). In the interim, this report puts on record one Clovis point from the Hickory Creek \#2 site. This Clovis point represents the first documented find from Houston County in the TCFPS (see Bever and Meltzer 2007:Table 1) .

The Houston County Clovis point was found at a depth of $60-70 \mathrm{~cm}$ bs (Unit 5, in Area B, see Figure 2) in U.S. Forest Service Passport in Time excavations in archeological deposits that predominantly contain Woodland period (ca. A.D. 200-700) chipped stone tools and lithic debris. No other Clovis era tools have been identified in the extensive $(+11,000)$ lithic assemblage from the site. The Hickory Creek specimen appears to be a nearly finished preform made of a gray Central Texas chert, with nearly parallel stem edges (Figure 19a-b). The Clovis preform is $73.0 \mathrm{~mm}$ in length, $27.3 \mathrm{~mm}$ in width, and has a thickness of $7.6 \mathrm{~mm}$. It was shaped by both percussion and fine pressure flaking, and one lateral blade edge appears to have been resharpened. The lateral stem edges and the base have not been ground. One side of the point has three flake scarsone large and two small flutes - while the other has one large flute and one small, later flute scar. The larger flake fluting scars range from 36.6-38.0 mm in length and 12.0-15.8 $\mathrm{mm}$ in width. 

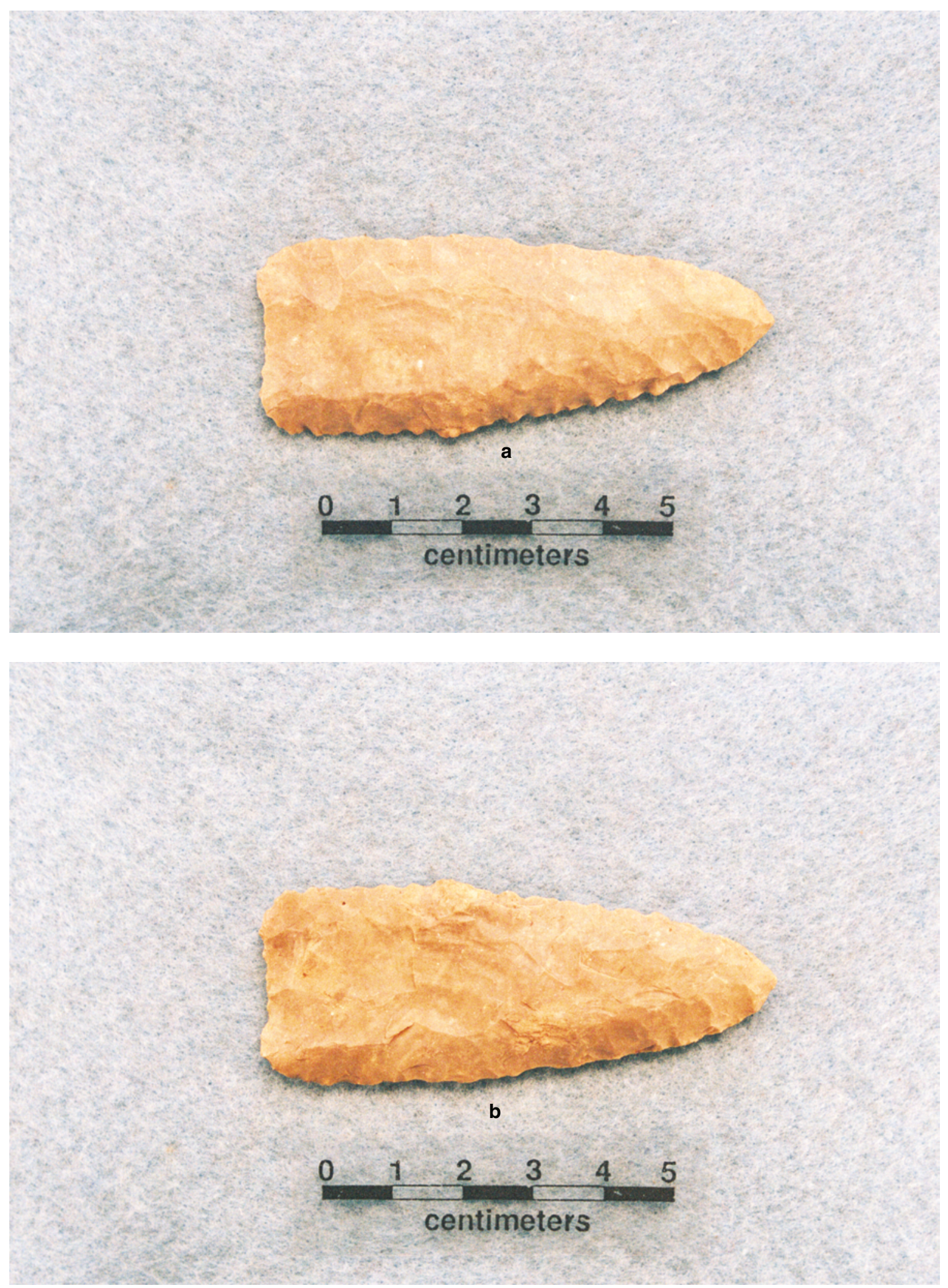

Figure 19. Clovis point from the Hickory Creek \#2 site: a, side A; b, side B. 


\section{Archaic and Woodland Period Dart Points}

\section{$41 \mathrm{HO13}$}

The one dart point from $41 \mathrm{HO} 13$ is a petrified wood Woodland era Kent point from Unit 1 (Figure 20a). This point came from deep in the archeological deposits.

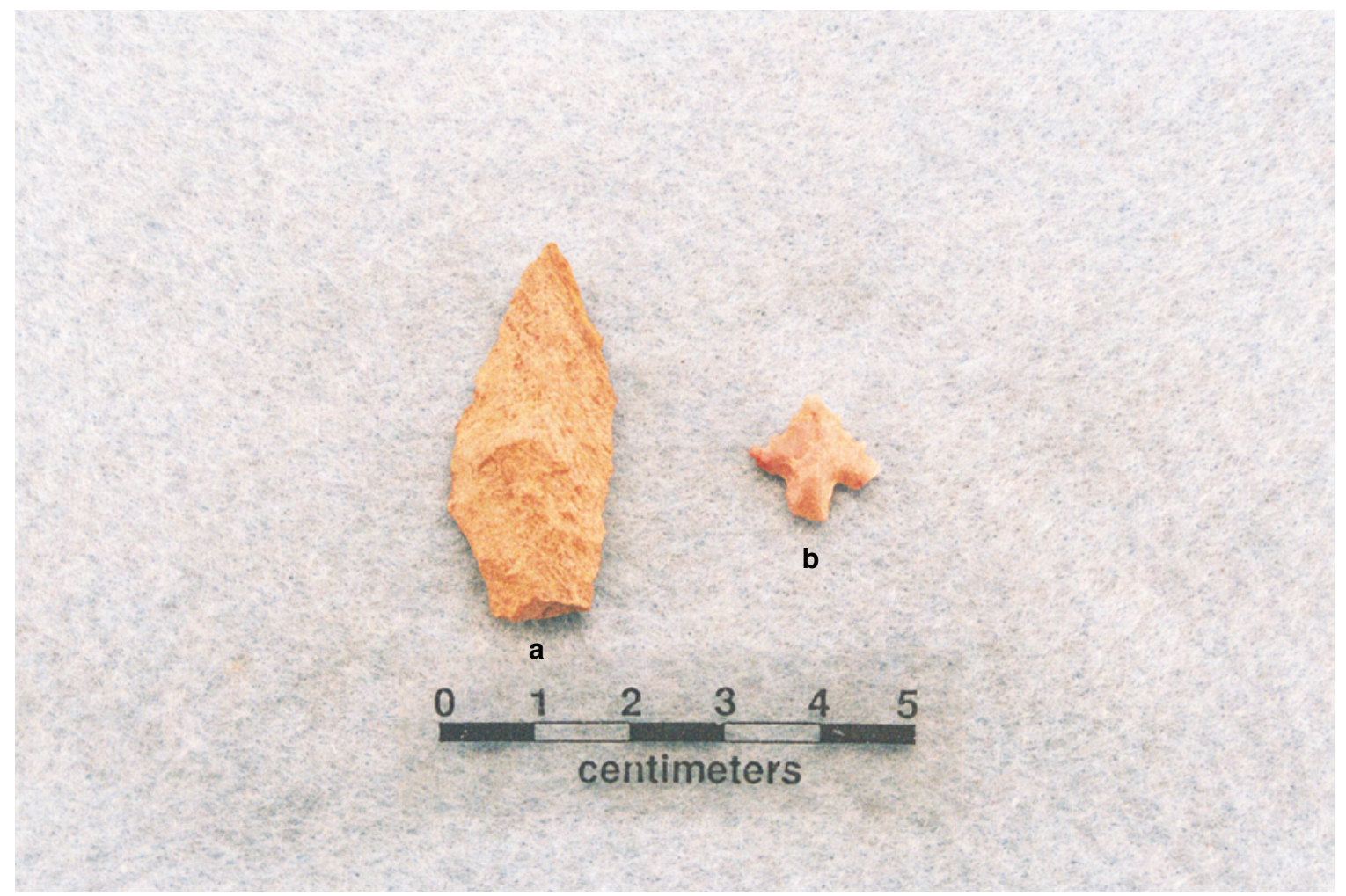

Figure 20. Projectile points from 41HO13: a, Kent dart point; b, cf. Steiner arrow point. Provenience: a, Unit 1, 100-110 cm bs; b, Unit 1, 40-50 cm bs.

\section{HC-1}

There are three dart points from this site. The first is a long and slender petrified wood Gary point (Figure 21a) from Unit 1 back dirt, and the other is a petrified wood Kent point (Figure 21b) from $80-90 \mathrm{~cm}$ bs in Unit 1A. A petrified wood blade and tip fragment was recovered from Unit $2 \mathrm{~A}(10-20 \mathrm{~cm}$ bs). The two typologically identifiable dart points indicate that site HC-1 was occupied during the Woodland period, probably the latter part of the period based on the relatively narrow stem width $(14.9 \mathrm{~mm})$ of the one Gary point (cf. Schambach 1982). 


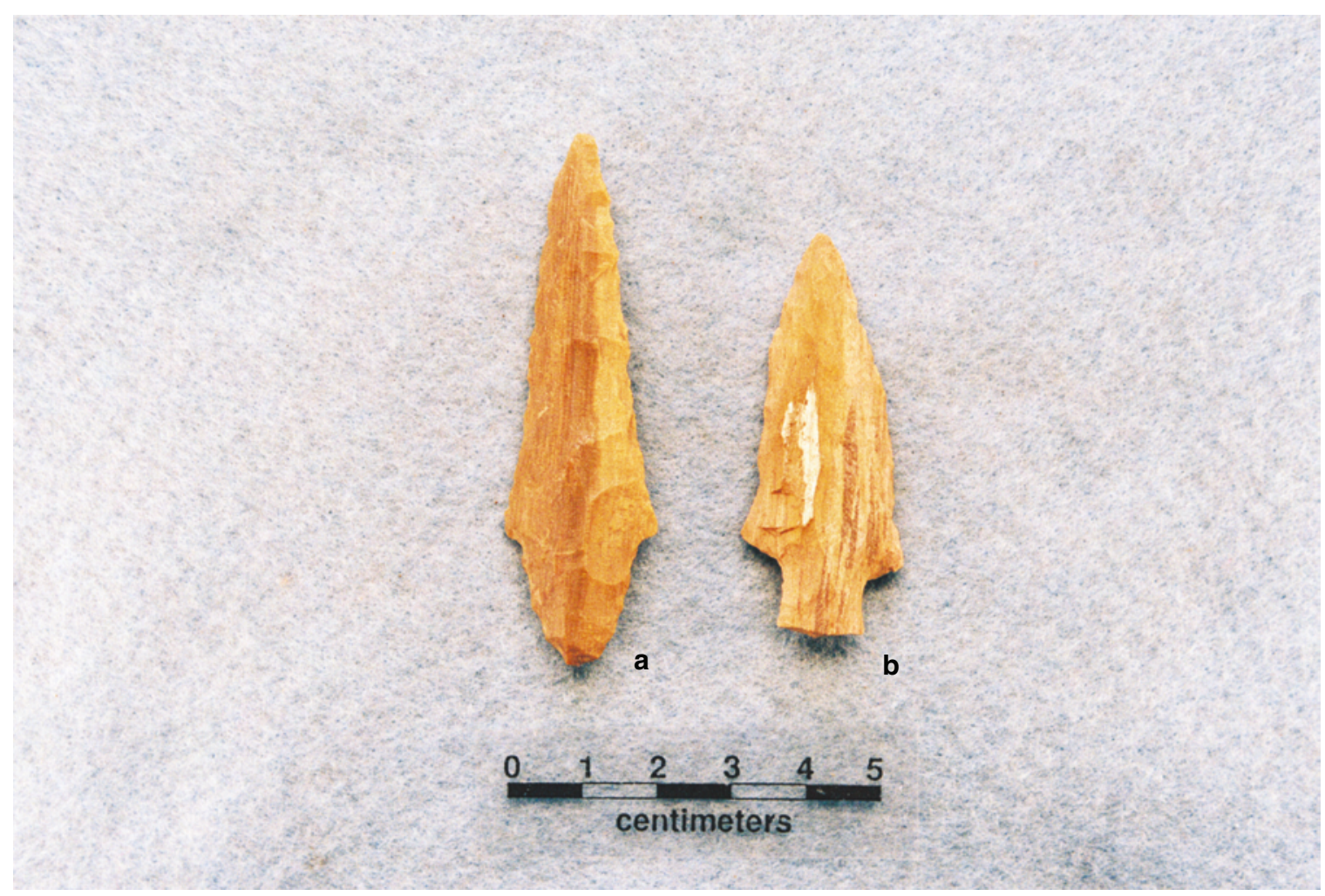

Figure 21. Dart points from HC-1: a, Gary point; b, Kent point. Provenience: a, Unit 1 back dirt; b, Unit 1A, 80-90 cm bs.

\section{Hickory Creek \#2 (HC-2)}

The 77 other dart points from the Hickory Creek \#2 site were made and used in Middle Archaic (ca. 6000-3000 B.C.), Late Archaic (ca. 3000-500 B.C.), and Woodland period (ca. 500 B.C. to A.D. 800) times. This includes 47 points and fragments from Area A (Table 10), 22 dart points and fragments from Area B (Table 11), and eight points and fragments from Looter Pits 3, 4, and 8 (with an unknown provenience).

Table 10. Provenience of dart points and dart point fragments from the Hickory Creek \#2 site, Area A.

$\begin{array}{lllllllllll}\text { Type lv. } 1 & \text { lv. } 2 & \text { lv. } 3 & \text { lv. } 4 & \text { lv. } 5 & \text { lv. } 6 & \text { lv. } 7 & \text { lv. } 8 & \text { lv. } 9 & \text { N }\end{array}$

\begin{tabular}{|c|c|c|c|c|c|c|c|c|c|c|}
\hline \multicolumn{11}{|c|}{ Woodland period } \\
\hline Gary & - & 1 & 1 & - & 5 & 2 & 4 & 1 & 1 & 15 \\
\hline Kent & - & - & - & - & - & 1 & 2 & 2 & - & 5 \\
\hline Godley & - & - & - & - & - & - & - & 2 & 1 & 3 \\
\hline Darl & - & - & - & - & - & - & - & 1 & 1 & 2 \\
\hline Marcos & - & - & - & - & - & - & - & - & 1 & 1 \\
\hline
\end{tabular}


Table 10. Provenience of dart points and dart point fragments from the Hickory Creek \#2 site, Area A, cont.

$\begin{array}{lllllllllll}\text { Type } & \text { lv. } 1 & \text { lv. } 2 & \text { lv. } 3 & \text { lv. } 4 & \text { lv. } 5 & \text { lv. } 6 & \text { lv. } 7 & \text { lv. } 8 & \text { lv. } 9 & \text { N }\end{array}$

Late Archaic/Woodland periods

Edgewood

Late Archaic period

Williams

Lone Oak

Bulverde

Middle Archaic period

Big Sandy

$\begin{array}{ll}- & - \\ - & - \\ - & -\end{array}$

Fragments

$-$

1

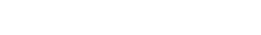

$\begin{array}{lllll}1 & - & - & - & 1 \\ - & - & 1 & - & 1 \\ 1 & - & - & - & 1\end{array}$

Totals

0

Note: This does not include one tip, one Gary point, one Yarbrough point (Late Archaic), one Kent point, one Woden point (Late Archaic-Woodland), and two Morrill (Late Archaic points from Unit 3 back dirt. ${ }^{5}$

Table 11. Provenience of dart points and dart point fragments from the Hickory Creek \#2 site, Area B.
Type
lv. 1
1v. 2
1v. 3
lv. 4
lv. 5
lv. 6
lv. 7
lv. 8
$\mathrm{N}$

\begin{tabular}{llllllllll}
\hline \multicolumn{2}{l}{ Woodland period } & & & & & & & & \\
Gary & - & 1 & - & 1 & 1 & - & - & 1 & 4 \\
Kent & - & - & - & - & - & - & 3 & - & 3 \\
Godley & - & - & - & - & - & - & 1 & 1 & 2
\end{tabular}

Late Archaic period

Lone Oak

Bulverde

Morrill

UID ES

Middle Archaic period

Dawson

Neches River* 
Table 11. Provenience of dart points and dart point fragments from the Hickory Creek \#2 site, Area B, cont.

\begin{tabular}{llllllllll}
\hline Type & lv. 1 & lv. 2 & lv. 3 & lv. 4 & lv. 5 & lv. 6 & lv. 7 & lv. 8 & $\mathrm{~N}$ \\
\hline $\begin{array}{l}\text { Fragments } \\
\text { and UID }\end{array}$ & - & - & 1 & - & - & 2 & 2 & - & 5 \\
\hline Totals & 0 & 1 & 1 & 2 & 3 & 3 & 8 & 4 & 22 \\
\hline
\end{tabular}

* Prewitt (2005:277) suggests that the proper name for this dart point style is Oletha, but we follow Turner and Hester (1999) in this instance.

UID=unidentified

In both Area A and Area B, the vast majority of the dart points and fragments are from the lower levels in the archeological deposits: $40-90 \mathrm{~cm}$ bs in Area A $(87.5 \%$, see Table 10) and $40-80 \mathrm{~cm}$ bs in Area B (82\%, see Table 11). By depth, the peak densities of dart points in Area A and Area B occur between $60-80 \mathrm{~cm}$ bs.

The dart points from the Hickory Creek \#2 site are grouped into temporal periods, including Woodland, Woodland-Late Archaic (for points whose absolute age remains ambiguous), Late Archaic, and Middle Archaic. The usefulness of these groupings should be evaluated with the proviso that the majority of dart point types that occur in East Texas are not yet well-dated by secure archeological association with a series of calibrated radiocarbon dates from features or single component archeological deposits, but the estimated temporal periods to which the dart points from the Hickory Creek \#2 site are the product of a few calibrated dates as well as extrapolations with better dated temporal sequences in the western Gulf Coastal Plain, Central Texas, and the Ozark Highlands (cf. Schambach 1982; Story 1990; Trubitt 2009; Turner and Hester 1999). Nevertheless, the groupings follow rather closely the artifact sequences for stone tools postulated by Story (1990:Figures 32 and 33) in her synthesis of the archeology of the East Texas portion of the Gulf Coastal Plain.

A simple comparison of the number of dart points from the site that fall into each of these periods make evident that Woodland period dart points are by far the most abundant (65.5\% of the 58 typologically-chronologically identifiable points), particularly the Gary $(n=21)$, Kent $(n=9)$, and Godley $(n=5)$ types (Table 12$)$. These points are notably abundant in the deeper archeological deposits (i.e., below $40 \mathrm{~cm} \mathrm{bs}$ ) in Area A ( $86 \%$ of all the dart points from those depths), but only comprise $50 \%$ of the dart points in the deeper archeological deposits in Area B. Furthermore, of the 34 Woodland period dart points identified in the artifact assemblage, 91\% come from the deposits between 40$90 \mathrm{~cm}$ bs; several other Woodland period points were found in looter holes and/or back dirt. 
Table 12. Summary of dart points by period, area, and depth from the Hickory Creek \#2 site.

\begin{tabular}{llllll}
\hline Type & $\begin{array}{l}\text { Area A, } \\
\text { lv. 1-4 }\end{array}$ & $\begin{array}{l}\text { Area B, } \\
\text { lv. 1-4 }\end{array}$ & $\begin{array}{l}\text { Area A, } \\
\text { lv. 5-9 }\end{array}$ & $\begin{array}{l}\text { Area B, } \\
\text { lv. 5-8 }\end{array}$ & $\begin{array}{l}\text { Looter } \\
\text { Holes and } \\
\text { back dirt }\end{array}$ \\
\hline Woodland & & & & & \\
Gary & 2 & 1 & 13 & 2 & 2 (1, Area A) \\
Kent & - & - & 5 & 3 & 1 (Area A) \\
Godley & - & - & 3 & 2 & - \\
Darl & - & - & 2 & - & - \\
Marcos & - & - & 1 & - & 3 (2, Area A) \\
Sub-total & 2 & 1 & 24 & 7 &
\end{tabular}

Woodland-Late Archaic

$\begin{array}{llllll}\text { Edgewood } & - & - & 1 & - & - \\ \text { Woden } & - & - & - & - & 1 \text { (Area A) } \\ \text { Sub-total } & - & - & 1 & - & 1 \text { (Area A) }\end{array}$

Late Archaic

parallel stemmed

Williams

Yarbrough

Morrill

Lone Oak

Bulverde

expanding

stemmed

Sub-total

1

3

4

5 (3, Area A)

Middle Archaic

\begin{tabular}{lccccc} 
Dawson & - & - & - & 1 & 1 \\
Big Sandy & 1 & - & - & - & - \\
Neches River & - & - & - & 2 & 1 \\
Sub-total & 1 & - & - & 3 & 10 \\
\hline Totals & 3 & 3 & 28 & 14 & 14 \\
\hline
\end{tabular}

Late Archaic dart points $(n=13)$ comprise another $22.4 \%$ of the recovered points (see Table 12); these include the Morrill $(n=4)$ and Bulverde $(n=3)$ types. They are found almost exclusively in the deeper archeological deposits as well, and are proportionally 
more abundant in Area B (28.6\%) than they are in Area A (10.7\%). There are only a few (8.6\%) dart points at the Hickory Creek \#2 site that likely date to the Middle Archaic period. Middle Archaic dart points are found in both Area A and B (see Tables 10-12), exclusively in the deeper archeological deposits in Area B, but are more common overall in Area B (17.6\%) than in Area A (3.2\%) (see Table 12).

The most recognizable Middle Archaic dart point from the site is an extensively resharpened and side-notched Big Sandy point from Area A (Figure 22a). The blade has been resharpened to form a bifacial scraper edge, and the point is made from a non-local white chert. Big Sandy points (also called White River Side Notched, see Trubitt 2009:78-79) are found in both upland and floodplain settings throughout the Western Gulf Coastal Plain as well as the Ouachita Mountains and western Ozark Highlands. Calibrated dates associated with the Big Sandy dart points range from 5200-4500 BC (6450-7150 calibrated years B.P.) (Trubitt 2009:79 and Table 4). Other Middle Archaic points include two Dawson and two Neches River (see Figure 25d) specimens, primarily from Area B.

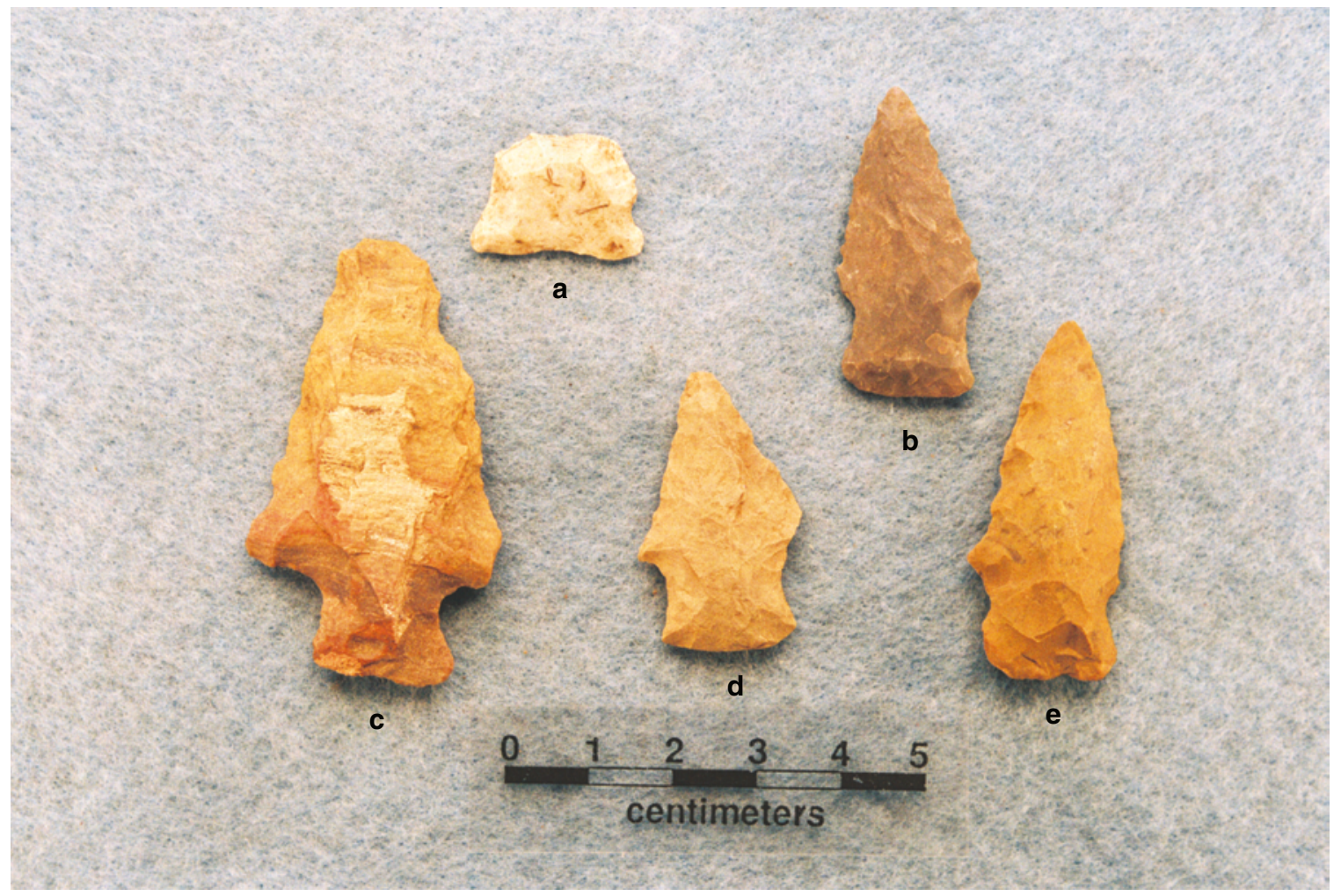

Figure 22. Selected dart points from the Hickory Creek \#2 site: a, Big Sandy; b, Yarbrough; c, unidentified expanding stem; d, Lone Oak; e, cf. Godley. Provenience: a, Unit 1, 10-20 cm bs; b, Unit 3 back dirt; c, Unit 1, 80-90 cm bs; d, Unit 1, 70-80 cm bs; e, Unit 4, 70-80 cm bs.

There are five Late Archaic dart point types in the Hickory Creek \#2 assemblage, including Morrill (Figures 23b, d-e and 24c-d) points from both Areas A and B, Williams from Area B, Yarbrough from Area A (see Figure 22b), Lone Oak points from both areas (see Figure 22d), and Bulverde points (Figure 23a, g-h) from both Areas A and 
B. Two other dart points are considered to be of Late Archaic age, based on the character of the point stem, but they have not been identified to a type. One is an extensively resharpened parallel-stemmed dart point with a flat base (Figure 23c), while the other is a large expanding stem petrified wood point from Area B (see Figure 22c).

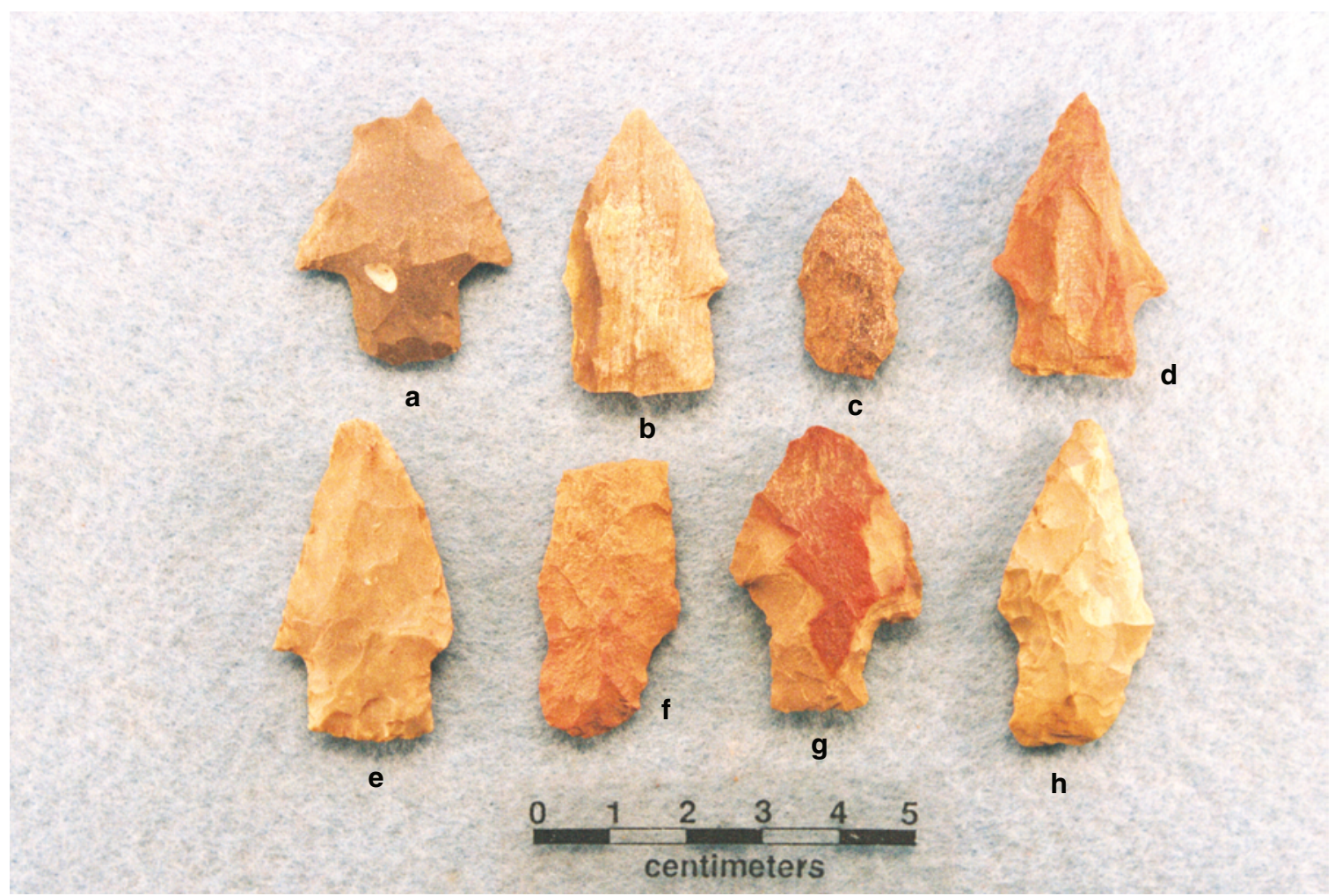

Figure 23. Parallel-stemmed dart points: a, g-h, cf. Bulverde; b, d-e, Morrill; c, unidentified parallel stemmed; f, Godley. Provenience: a, Unit 6, $50 \mathrm{~cm}$ bs; b, d, Looter Hole 3 back dirt; c, Unit 1, 40-50 cm bs; e, Looter Hole 4; f, Unit 1, 70-80 cm bs; g, Unit 4, 50-60 cm bs; h, Unit 6, 30-40 cm bs. 


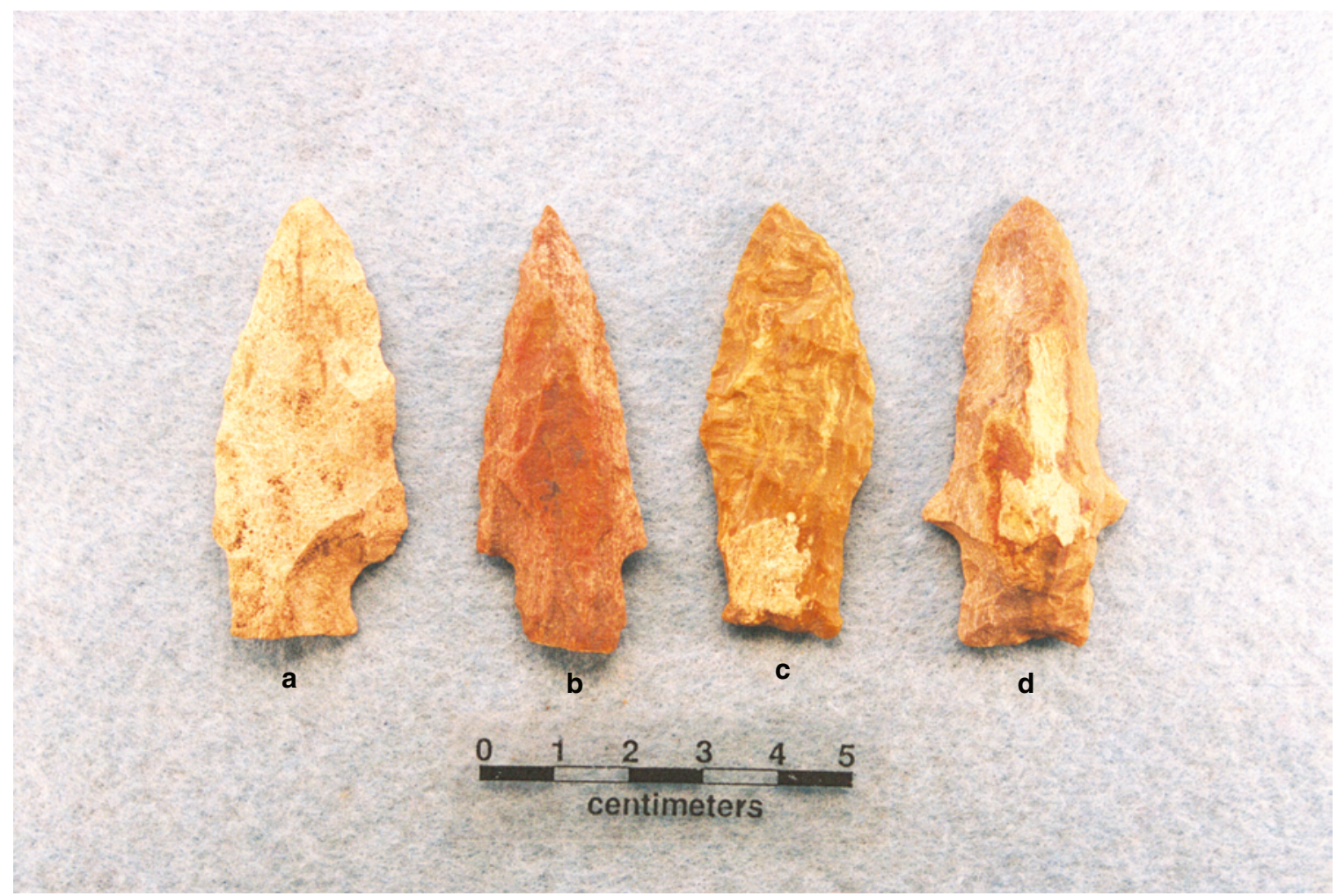

Figure 24. Dart points from the Hickory Creek \#2 site: a, Woden; b, Kent; c, Morrill; d, cf. Morrill. Provenience: a, Looter Hole 2, back dirt; b, Unit 5, 50-60 cm bs; c, Unit 6, $72 \mathrm{~cm}$ bs; d, Unit 4A, 50-60 cm bs.

The Edgewood and Woden points, both from Area A, are considered in this analysis as both Late Archaic to Woodland period in age, although temporal considerations offered by Turner and Hester (1999:Figure 3-7) and Shafer and Walters (in press) suggest it is equally likely that both were made and used in Woodland period times; Shafer and Walters (in press) consider many of what would otherwise be classified as Woden point (see Figure 24a) to be a variety of Gary point. Since there are only two of these points in the entire sample of dart points from the Hickory Creek \#2 site, a possible inaccurate temporal classification of the two types will not alter any temporal conclusions reached by a broader consideration of the styles of the recovered dart points (see below).

As previously mentioned, the principal Woodland period dart points in both Area $A$ and B at the Hickory Creek \#2 site include contracting stem Gary points (Figures 25f, 26a-g, and 27a-g), Kent points (Figure 25a, c, e, g-i; see also Figure 24b), and Godley points (see Figures 22e and 23f). Other Woodland period dart points present in Area A include examples of the Darl $(n=2)$ and Marcos $(n=1)$ types. There is also a narrow contracting stem dart point from Area B made from a gray novaculite (Figure 25b); this material may have been obtained in the Red River gravels more than $250 \mathrm{~km}$ to the north. 


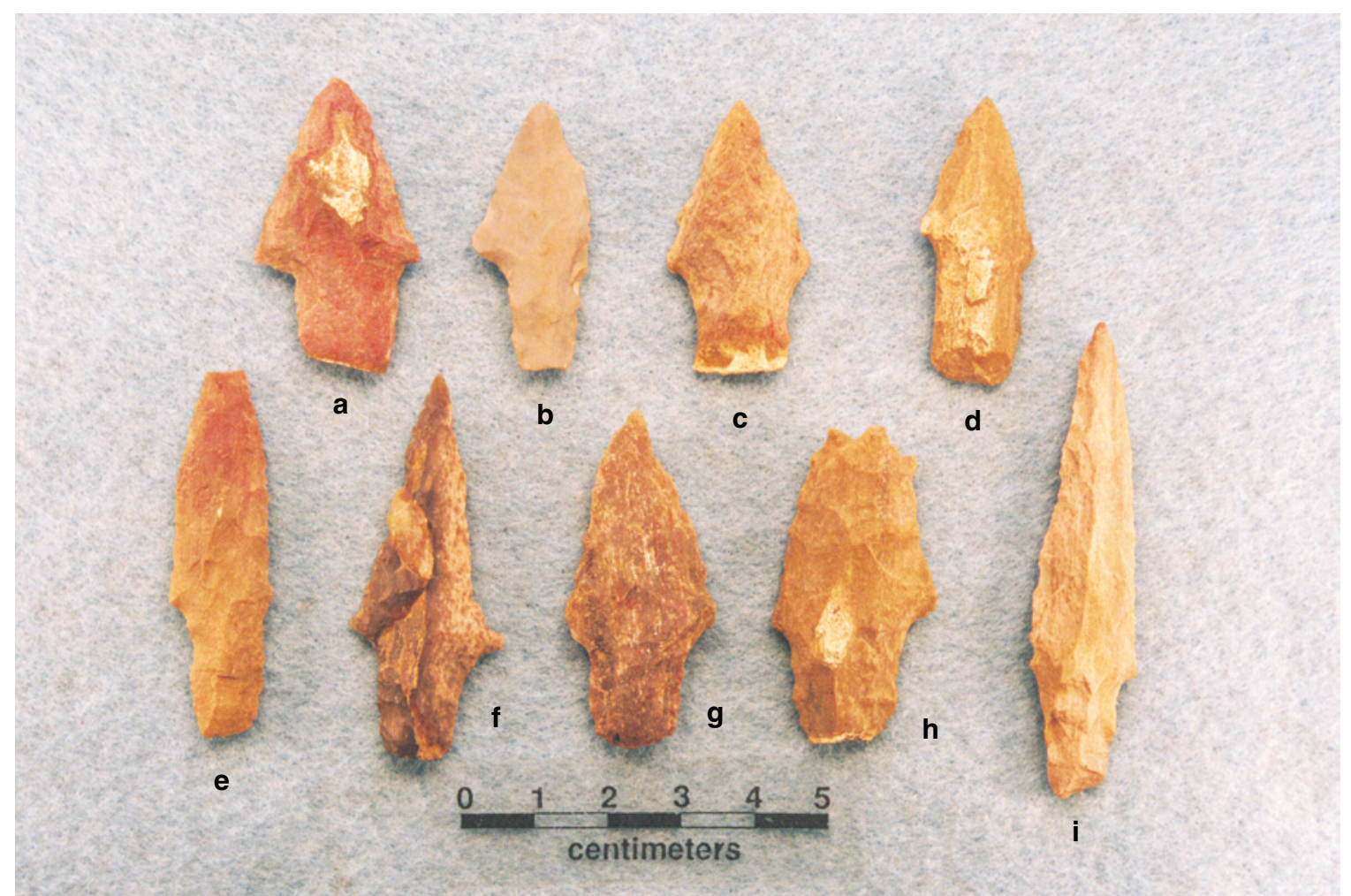

Figure 25. Kent dart points and other dart points: a, c, e, g-i, Kent; b, unidentified contracting stem (novaculite); d, Neches River; f, Gary. Provenience: a, e, Unit 1, $70-80 \mathrm{~cm}$ bs; b, Unit $6,80 \mathrm{~cm}$ bs; c, Unit 3, back dirt; d, Unit 6, 40-50 cm bs; f, Unit 2, 50-60 cm bs; g, Unit 2, 60-70 cm bs; h, Unit 6, $72 \mathrm{~cm}$ bs; i, Unit 1, 60-70 cm bs. 


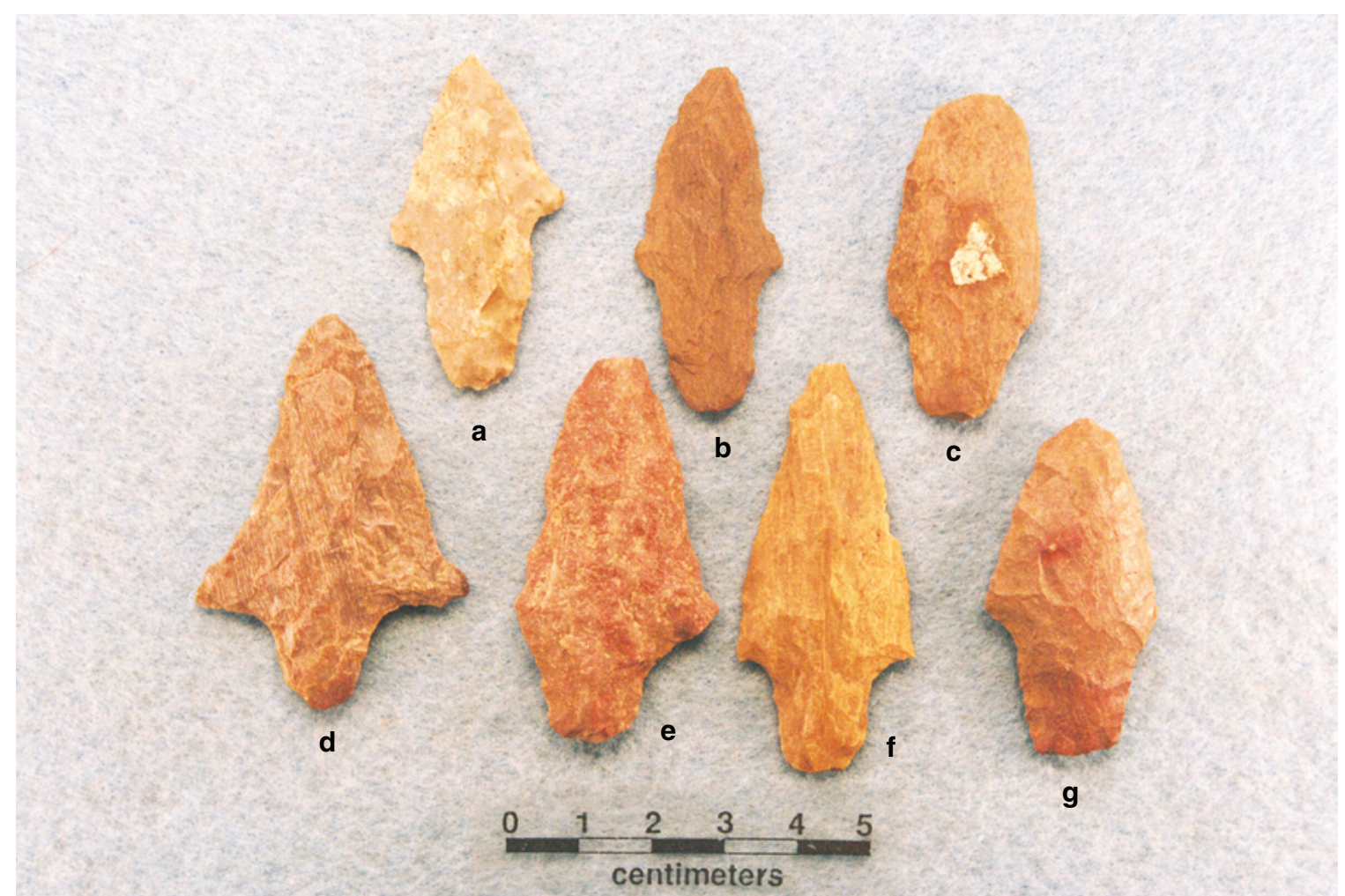

Figure 26. Gary dart points. Provenience: a, Unit 4, 60-70 cm bs; b, Unit 2, $40-50 \mathrm{~cm}$ bs; c, Unit 3A, 40-50 cm bs; d, Unit 6, 10-20 cm bs; e, Unit 4A, 40-50 cm bs; f, Unit 5, 30-40 cm bs; g, Unit 1, 40-50 cm bs. 


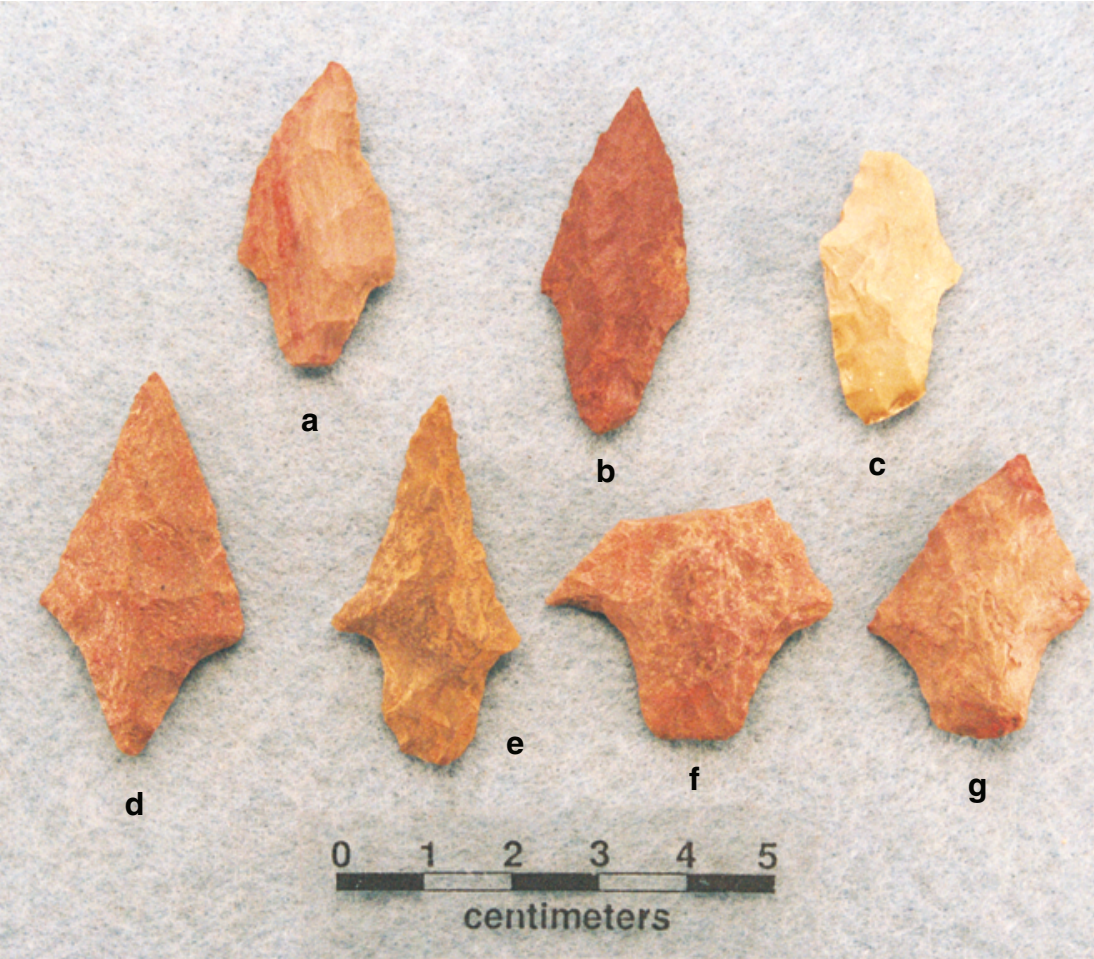

Figure 27. Contracting stem Gary dart points from the Hickory Creek \#2 site. Provenience: a, Unit 2, 50-60 cm bs; b, Looter Hole 8; c, Unit 2, 20-30 cm bs; d, Unit 2, 60-70 cm bs; e, Unit 3A, 40-50 cm bs; f, Unit 4, 60-70 cm bs; g, Unit 4, 70-80 cm bs.

The Gary points from the Hickory Creek \#2 site are relatively thin and have narrow stem widths. Thickness measurements of Gary points from $40-70 \mathrm{~cm}$ bs (the only levels with between 2-5 measured points) range from $7.66-8.43 \mathrm{~mm}$, and stem width measurements range between 13.73-14.1 mm. These thickness and stem width measurements for the Gary points from the site-and from the deeper archeological deposits - are consistent with the Gary, var. Camden type-variety defined by Schambach (1982:Tables 7-2 to 7-4). In Schambach's scheme, the Gary, var. Camden is the latest variety of Gary point, and they were made and used between ca. A.D. 200-700.

Several different kinds of lithic raw materials were used in the manufacture of the dart points that ended up discarded at the Hickory Creek \#2 site (Table 13), including a variety of cherts (most of non-local origin); petrified wood, quartzite, and Glover quartzite, locally available raw materials; and novaculite, a non-local raw material that originated in the Ouachita Mountains of southwestern Arkansas and southeastern Oklahoma and can also be found in Red River gravels. It is clear that local lithic raw materials were mainly used in dart point manufacture during all temporal periods of occupation at the site except that of the Paleoindian period (Clovis era), particularly petrified wood of varying knapping quality (cf. Girard 1995). Quartzite gradually became more important for dart point manufacture during and after the Late Archaic period, including the evidence of the use of the very coarse-grained Glover quartzite, while the 
use of cherts diminished from 38.5-40\% in the Middle and Late Archaic periods to only $18.5 \%$ in the Woodland period (Table 13 ).

Table 13. Lithic raw material use in the dart points from the Hickory Creek \#2 site, by estimated temporal period.

\begin{tabular}{|c|c|c|c|c|c|}
\hline Period & Chert & $\begin{array}{l}\text { Petrified } \\
\text { Wood }\end{array}$ & Quartzite & $\begin{array}{l}\text { Glover } \\
\text { quartzite }\end{array}$ & Novaculite \\
\hline $\begin{array}{l}\text { Paleoindian } \\
\text { Middle }\end{array}$ & $100.0 *$ & - & - & - & - \\
\hline Archaic & 40.0 & 60.0 & - & - & - \\
\hline Late Archaic & 38.5 & 46.7 & 15.4 & - & - \\
\hline Late Archaic- & & & & & \\
\hline Woodland & 50.0 & 50.0 & - & - & - \\
\hline Woodland & 18.5 & 57.9 & 18.4 & 2.6 & 2.6 \\
\hline
\end{tabular}

These trends in the use of lithic raw materials, particularly the cherts that most likely were from gravels that originated from source areas to the west in Central Texas, suggest that the aboriginal populations that utilized the Hickory Creek valley prior to ca. 2500 years ago had access to a wide range of non-local lithic raw materials. This is probably because they were relatively mobile foraging populations prior to 2500 years ago in this area that ranged west into the Trinity and Brazos River valleys - where high quality cherts could be obtained from gravel sources - and where they collected these high-quality lithic resources during the course of their settlement and foraging forays. After about 2500 years ago, Woodland period groups (as well as later Caddo groups at the Hickory Creek \#2 site, see below) relied much more frequently on locally available lithic raw materials as sources of chipped stone tools. These later groups that used the Hickory Creek valley likely had a more territorially-confined settlement/foraging area in the East Texas Pineywoods, although certainly there were contacts between Pineywoods Woodland and Caddo groups and peoples living in areas with high quality chert raw materials that led to the continued acquisition of non-local chipped stone for tool manufacture and use.

\section{$\mathrm{HC}-3$}

All five of the dart points from the site were found from $0-50 \mathrm{~cm}$ bs. There are two blade/tip fragments of gray chert and dark gray chert. The others include petrified wood and grayish-brown chert Kent points (Figure 28a, c) from 40-50 cm bs and a gray chert Bulverde point (Figure $28 \mathrm{~b}$ ) from $20-30 \mathrm{~cm}$ bs. These points suggest intermittent use of the site for hunting from Late Archaic to Woodland period times. 


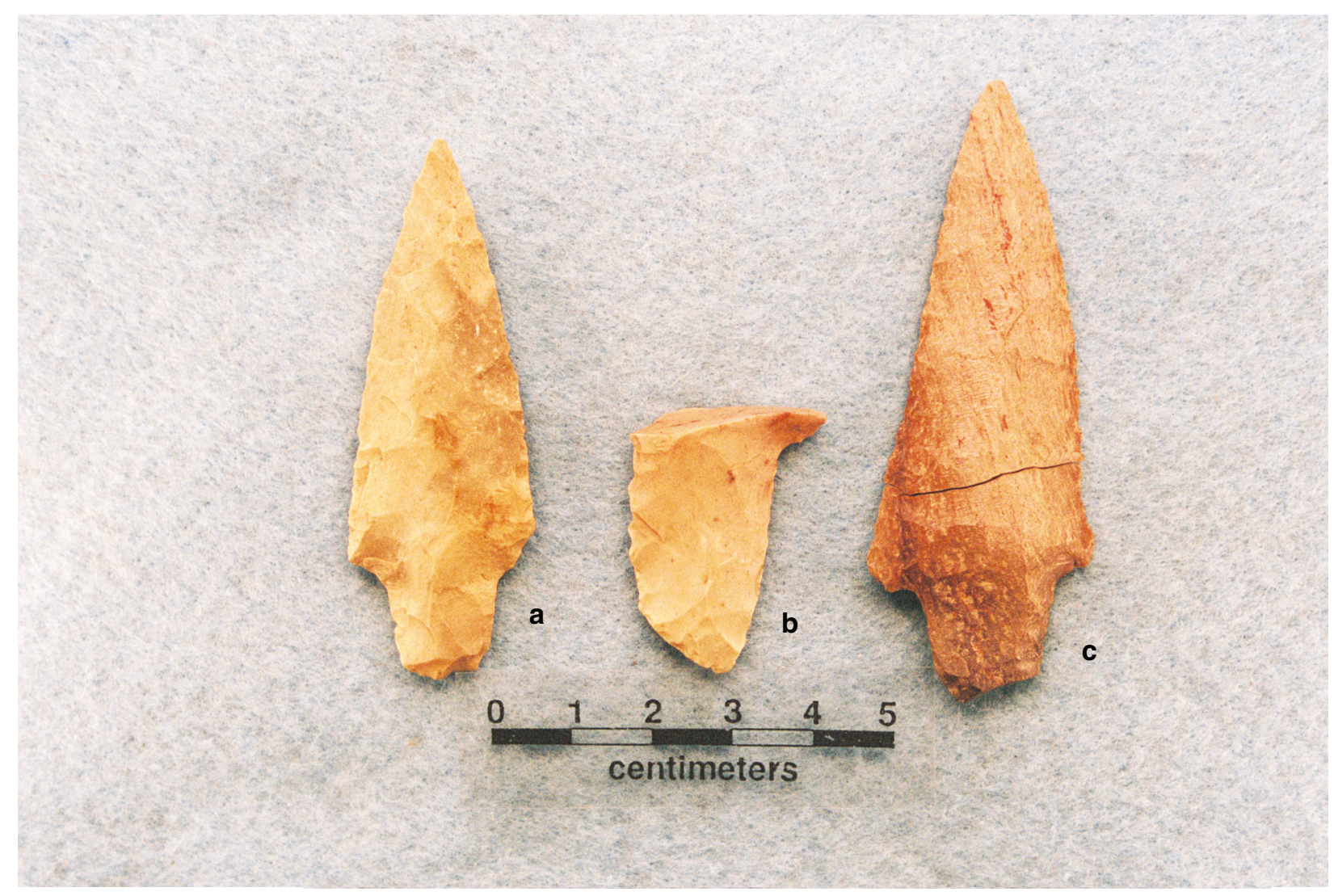

Figure 28. Dart points from HC-3: a, c, Kent; b, Bulverde. Provenience: a, c, Unit 1, $40-50 \mathrm{~cm}$ bs; b, Unit 1, 20-30 cm bs.

\section{Arrow points}

\section{$41 \mathrm{HO13}$}

A late Woodland (ca. A.D. 700-900; see discussion in Shafer and Walters in press) Steiner arrow point was recovered from $40-50 \mathrm{~cm}$ bs (see Figure 20b). It has been made from a Central Texas gray chert.

\section{Hickory Creek \#2 (HC-2)}

There are 34 arrow points and arrow point preforms/fragments in the chipped stone tools from the Hickory Creek \#2 site. About 84\% of the arrow points with vertical provenience data are from Area A, with the remainder from Area B (Table 14). By depth, $70 \%$ of the arrow points in Area A are from $10-30 \mathrm{~cm}$ bs, and $87.5 \%$ of the Area B arrow points are from 0-30 cm bs. The majority of the typologically identifiable arrow points at the site are Perdiz $(n=14)$, with one to three examples of Perdiz-Bonham, Alba, Steiner, and Friley types (Table 14). In Area B, Perdiz points are the only identified arrow point type, while the range of stemmed arrow points from Area A suggests several periods of use from later Woodland period times to the early $15^{\text {th }}$ century A.D. 
Table 14. Provenience of arrow points from the Hickory Creek \#2 site.

\begin{tabular}{|c|c|c|c|c|c|c|c|c|}
\hline \multirow[t]{2}{*}{ Type } & \multicolumn{4}{|c|}{ Area A (Units 1-4) } & \multicolumn{4}{|c|}{ Area B (Units 5-7) } \\
\hline & lv. 1 & lv. 2 & lv. 3-4 & lv. $5+$ & lv. 1 & lv. 2 & lv. $3-4$ & lv. $5+$ \\
\hline Perdiz & 2 & 4 & 4 & - & 2 & 1 & - & 1 \\
\hline Perdiz-Bonham & - & 1 & - & - & - & - & - & - \\
\hline Alba & - & - & - & 1 & - & - & - & - \\
\hline Steiner & - & 1 & - & 1 & - & - & - & - \\
\hline Friley & - & - & - & 1 & - & - & - & - \\
\hline Preforms and Fragments & 1 & 1 & 5 & 1 & 1 & - & 3 & - \\
\hline Totals & 3 & 7 & 9 & 4 & 3 & 1 & 3 & 1 \\
\hline
\end{tabular}

Note: This does not include one Steiner and one Friley arrow point from Looter Pit 3, or the one arrow point fragment from Looter Pit 8.

The earliest arrow point forms at the Hickory Creek \#2 site include the Friley (Figure 29a-b), Steiner (Figure 29c, e), and Alba (Figure 29d) types. Of those found in controlled contexts, three of the four points occur at depths between $40-90 \mathrm{~cm}$ bs (see Table 14 and Appendix 2); one possible Steiner (Figure 30e), classified as such because it has upward projecting barbs on the blade, was recovered from 10-20 cm bs in Unit 3. Friley and Steiner arrow points, the earliest arrow point forms in the region, are considered diagnostic of late Woodland (ca. A.D. 700-800+) components in East Texas (Perttula and Nelson 2004:160; Shafer and Walters in press). Alba points, on the other hand, are Formative to Early Caddo period (ca. A.D. 800-1200) arrow points, and are particularly well-represented at the George C. Davis site on the Neches River (Newell and Krieger 2000:161 and Figure 56a-h), where they are considered the only "resident type." 


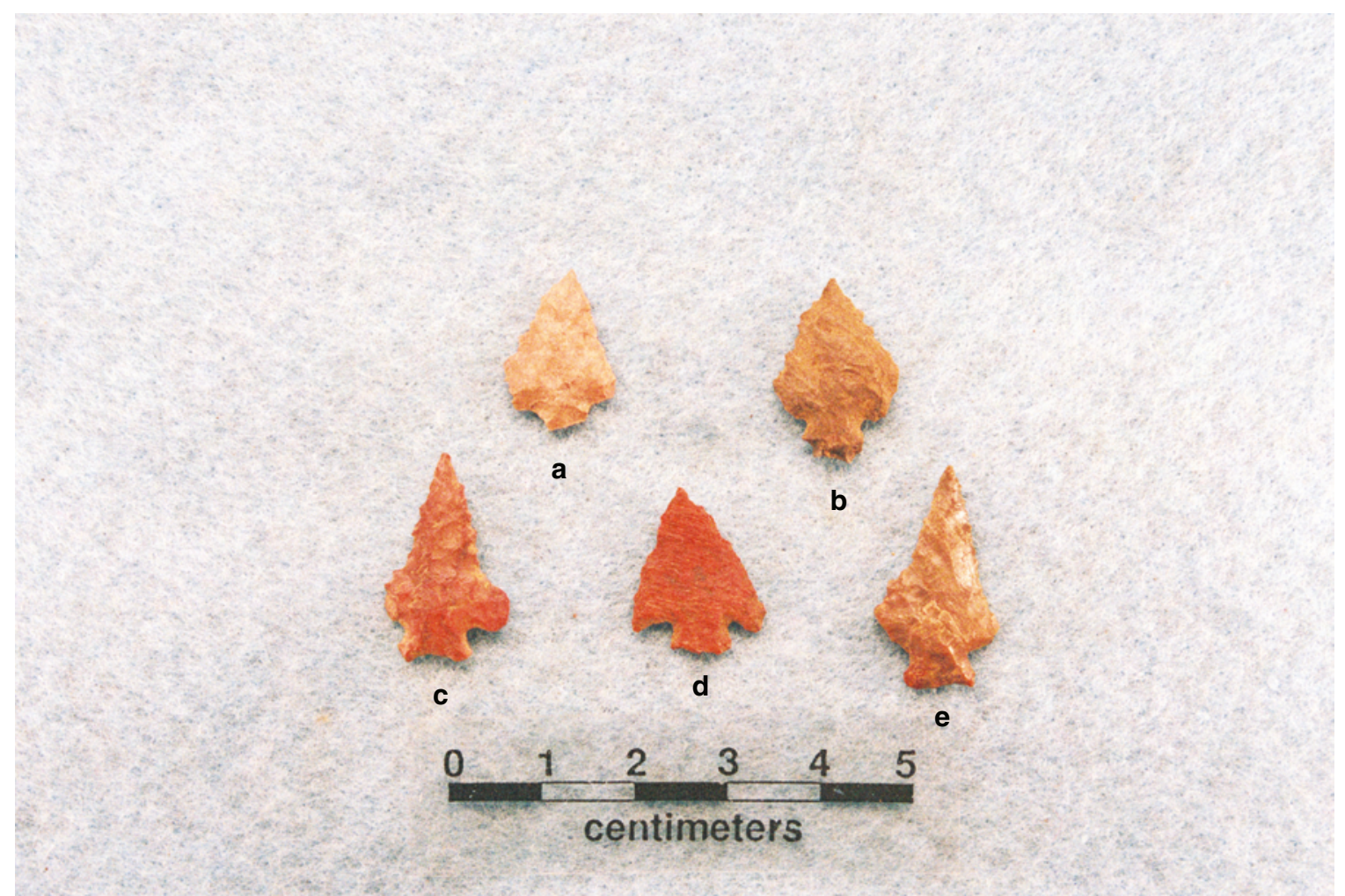

Figure 29. Early arrow point forms at the Hickory Creek \#2 site: a-b, Friley; c, e, Steiner; d, Alba. Provenience: a, Unit 2, 40-50 cm bs; b-c, Unit 3 back dirt; d, Unit 4A, lv. 9, back dirt; e, Unit 2, 50-60 cm bs. 


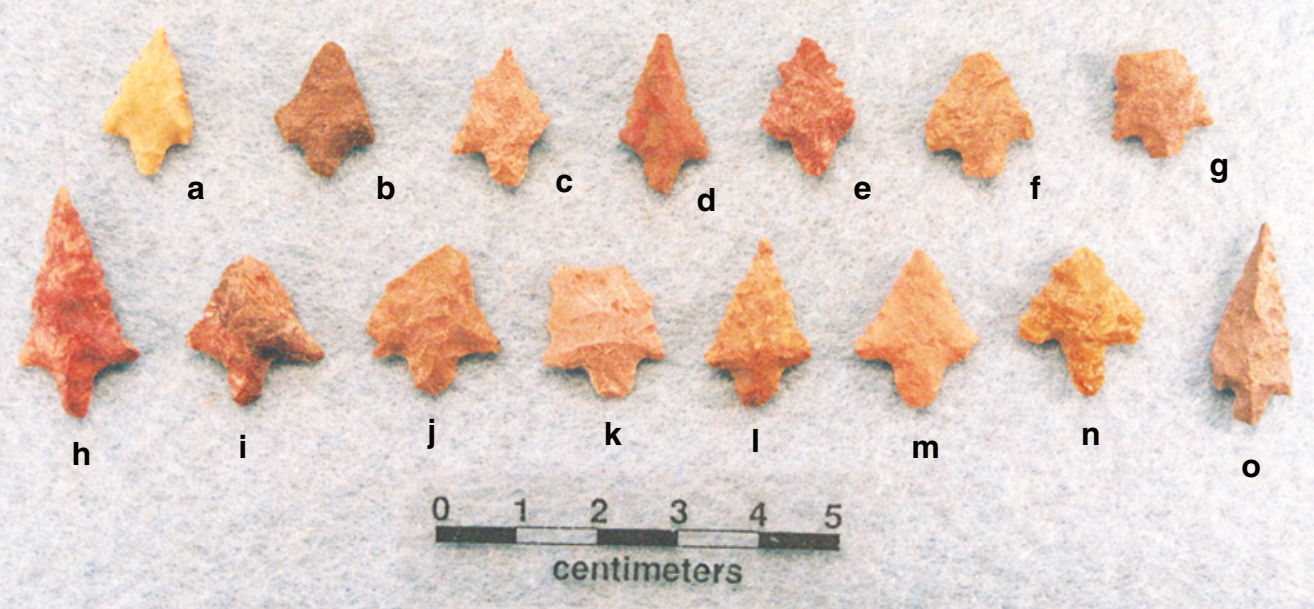

Figure 30. Perdiz, Perdiz-Bonham, and Steiner arrow points from the Hickory Creek \#2 site: a-d, f-n, Perdiz; e, cf. Steiner; o, Perdiz-Bonham. Provenience: a, j-k, Unit 3, 20-30 cm bs; b-c, l, Unit 3, 10-20 cm bs; d, Unit 3A, 0-10 cm bs; e, Unit 3A, 10-20 cm bs; f, h, Unit 6, 0-10 cm bs; g, i, Unit 4, 0-10 cm bs; m, Unit 6, 10-20 cm bs; n, Unit 4, 20-30 cm bs; o, Unit 1, 10-20 cm bs.

The later (post-ca. A.D. 1200-1300) arrow points at the Hickory Creek \#2 site are dominated by Perdiz points in both Area A and B (see Figure 30a-d, f-n and Table 14). Perdiz points have been found in East Texas Caddo sites that date from the $13^{\text {th }}$ to the $17^{\text {th }}$ century A.D., but as of yet, unfortunately, no temporally distinctive varieties have been defined within this broad span of time that would permit a more definitive conclusion as to the age of the prehistoric occupations at the site.

The one Perdiz-Bonham point (see Figure 30a) from the site has a narrow parallel to contracting stem and a flat base. It resembles a style of arrow points recovered from post-A.D. 1200 to ca. A.D. 1300 burial features at the George C. Davis site (see Shafer 1973) as well as at other sites of Middle Caddo period age where possible Alba, Bonham, and Perdiz arrow point forms may co-occur or be contemporaneous (Cliff and Perttula 2002:84-85 and Figure 30c, e, i; Perttula and Nelson 2003:114-115 and Figure 4.11a-e). Shafer (1973:207 and Figure 17Z-T1) noted that "most specimens fall within the Alba range but certain specimens clearly fall into the Perdiz type as well. The variation from one type to the other is indeed gradual and to separate one from the other would imply a distinction that does not visibly exist." It is suspected that there are gradual changes in the form of certain stemmed arrow points through time (from ca. A.D. 1200 to the $15^{\text {th }}$ century), leading from what is called the Alba type, to the Bonham type, to that of the Perdiz type, with subtle differences in stem shape, basal form, and shoulder/barb margins, 
and probably also associated with changes in raw material use for arrow points. The Perdiz-Bonham arrow point from the Hickory Creek site fall within the continuous evolutionary development of certain stemmed Caddo arrow points, sharing attributes of both Alba and Perdiz points, as well as Bonham and Bassett points, but lacking a prominent contracting stem. Shafer (2007:Figure 1a-c, 2008:Figure 1g-m) refers to many of these from $14^{\text {th }}$ and early $15^{\text {th }}$ century sites in Smith County, Texas, as "Perdiz-Bassett," but we prefer the moniker "Perdiz-Bonham" (Perttula 2008:450) because the character of the stem on these points is much more like that of a Bonham than the small pointed and contracting stem of Bassett points (see Turner and Hester 1999:201-202).

The arrow points from the Hickory Creek \#2 site are predominantly manufactured from local quartzite and petrified wood (Table 15); 81\% of the identifiable points are made from these materials. Only a small number of Perdiz points are made from chert or the coarsely-grained Glover quartzite, but the use of these materials at least indicates that the later Caddo knappers that lived at the site had a broader range of lithic raw materials to draw upon than was the case in earlier times (although the diversity in raw material use may simply be a product of differences in sample sizes). The early series of stemmed arrow points (Friley, Steiner, and Alba) were made exclusively of petrified wood and quartzite.

Table 15. Lithic raw material use in the arrow points from the Hickory Creek \#2 site.

\begin{tabular}{|c|c|c|c|c|c|}
\hline Type & Chert & Petrified Wood & Quartzite & $\begin{array}{l}\text { Glover } \\
\text { quartzite }\end{array}$ & $\mathrm{N}$ \\
\hline Perdiz & $21.4^{*}$ & 35.7 & 35.7 & 7.1 & 14 \\
\hline \multicolumn{6}{|l|}{ Perdiz- } \\
\hline Bonham & - & - & 100.0 & - & 1 \\
\hline Alba & - & 100.0 & - & - & 1 \\
\hline Steiner & - & 66.7 & 33.3 & - & 3 \\
\hline Friley & - & - & 100.0 & - & 2 \\
\hline Totals & 14.3 & 38.1 & 42.9 & 4.8 & 21 \\
\hline
\end{tabular}

\section{Bifaces}

\section{Hickory Creek \#2 (HC-2)}

A total of 50 bifaces and biface fragments, the discarded efforts in the manufacture of bifacially chipped and shaped tools (primarily dart points), are in the chipped stone lithics from the Hickory Creek \#2 site (Figure 31a-g), including five 
preforms for the manufacture of dart points (Figure 32c). The bifaces are made from petrified wood (48\%), quartzite (32\%), Glover quartzite (2\%), and cherts $(22 \%)$.

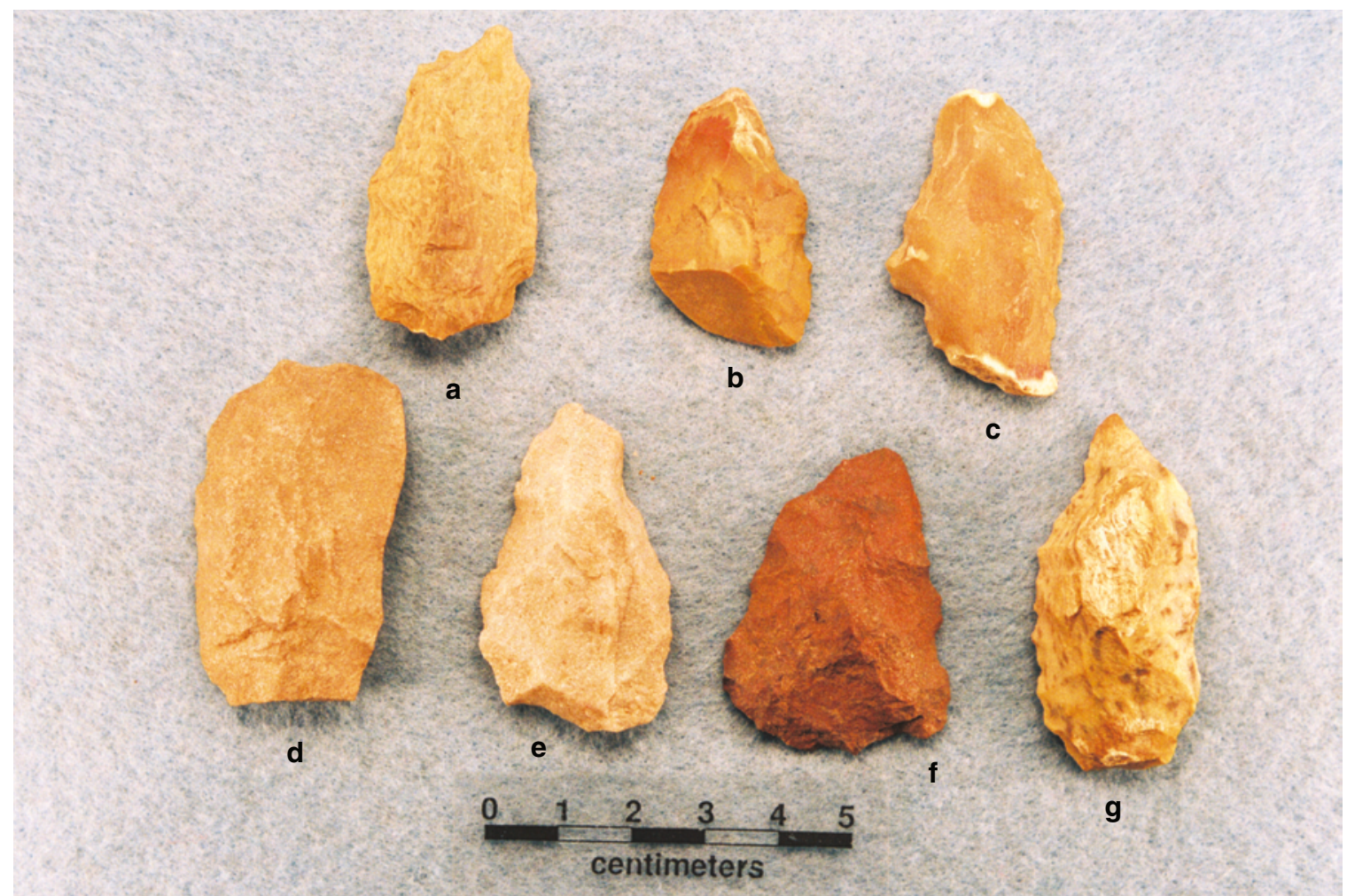

Figure 31. Bifaces from the Hickory Creek \#2 site. Provenience: a, Unit $6,70-80 \mathrm{~cm}$ bs; b, Pothole 8; c, Unit 6, 60-70 cm bs; d, Unit 6, 40-50 cm bs; e-f, Unit 4, 50-60 cm bs; g, Unit 2, 30-40 cm bs. 


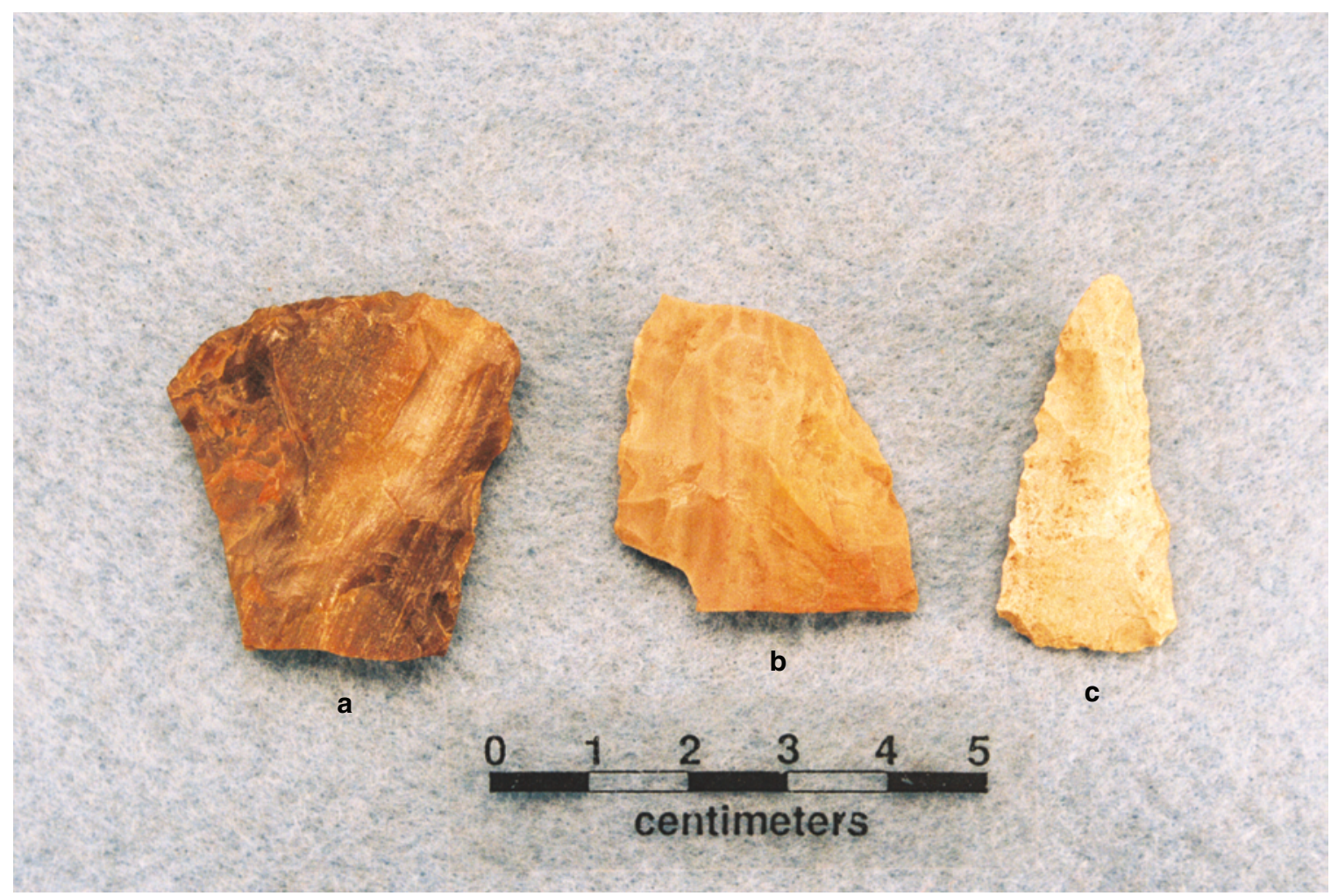

Figure 32. Bifacial tools and preforms: a, bifacial scraper; b, gouge; $c$, chert bifacial preform. Provenience: a, Unit 3, 40-50 cm bs; b, Pothole 8; c, Unit 2, 60-70 cm bs.

Of the bifaces with vertical provenience in Area A (Units 1-4) and Area B (Units 5-7) (see Figure 2), the majority of them are recovered from depths below 40-50 cm bs. In Area A, $68 \%$ of the bifaces are found from $40-90 \mathrm{~cm}$ bs; there is a second peak of bifaces in Level $2(10-20 \mathrm{~cm}, \mathrm{n}=6,19 \%)$, however, suggesting the continued manufacture of bifacial tools during the prehistoric Caddo occupation. In Area B, $65 \%$ of the bifaces are found from $40-80 \mathrm{~cm}$ bs. Thus, the bifaces and biface fragments are primarily from the archeological deposits at the site that are dominated by Woodland and Late Archaic dart points and/or sandy paste Woodland period pottery.

HC-3

A single chert bifacial tool fragment was recovered from $40-50 \mathrm{~cm}$ bs in Unit 1.

\section{Flake tools}

\section{$41 \mathrm{HO} 13$}

A single flake tool with use worn areas came from $60-70 \mathrm{~cm}$ bs in Unit 1. It was made from a Central Texas gray chert. 


\section{Hickory Creek \#2 (HC-2)}

The 44 flake tools from the Hickory Creek \#2 site include one bifacial scraper (see Figure 32a), three bifacially chipped drills (Figure 33d), three end or side scrapers, three petrified wood gouges (see Figure 32b), and 34 expedient flake tools with one or more lateral edges with evidence of use wear (Figure 33a-c, e-h). Chert was the lithic raw material of choice in the manufacture and use of flake tools $(70.5 \%, \mathrm{n}=31$, Figure $31 \mathrm{a}-\mathrm{d}$, g-h), followed by petrified wood $(25 \%, n=11$, Figure $31 \mathrm{f})$, and Glover quartzite $(4.5 \%$, $\mathrm{n}=2$, Figure $33 \mathrm{e}$ ).

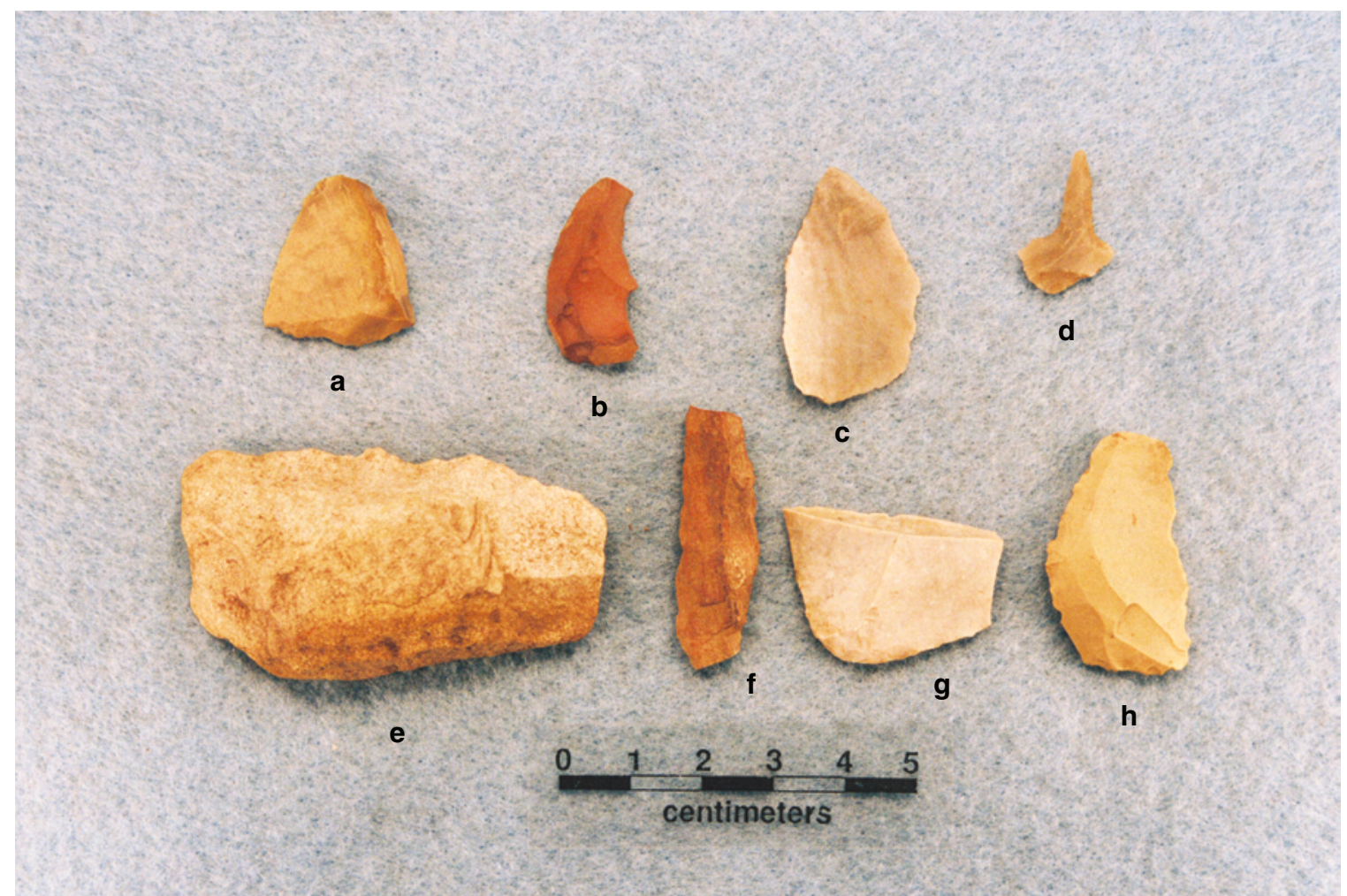

Figure 33. Flake tools and a drill from the Hickory Creek \#2 site: a-c, e-h, expedient flake tools; d, drill. Provenience: a, Unit 4, 60-70 cm bs; b-c, Unit 1, 60-70 cm bs; d, Unit 3, 20-30 cm bs; e, g, Pothole 5; f, Unit 4A, 80-90 cm bs; h, Unit 4, 50-60 cm bs.

In Area A, flake tools are abundant in both Caddo $(n=9)$ and Woodland/Late Archaic $(n=16)$ archeological deposits. In the upper Caddo deposits, there are expedient flake tools (56\%), a single petrified wood gouge, as well as two scrapers and one drill. The lower Woodland and Late Archaic deposits are dominated by expedient flake tools $(88 \%)$ and drills $(n=2)$. All of the flake tools from Area B from buried contexts are found between $40-80 \mathrm{~cm}$ bs. These include expedient flake tools (91\%) and a petrified wood gouge from $60-70 \mathrm{~cm}$ bs.

$\mathrm{HC}-3$

Five flake tools were found in the excavations of Unit 1 , three from $0-20 \mathrm{~cm}$ bs, one from 50-60 cm bs, and one from Looter Hole 2. Three of the five are made on chert 
raw materials $(60 \%)$, another is on the local petrified wood, and the remaining flake tool is made from quartzite.

\section{Lithic debris}

$\mathrm{HC}-1$

A single cortical piece of quartzite lithic debris is in the HC 1 collections (Unit $1 \mathrm{~A}, 30-40 \mathrm{~cm}$ bs).

\section{Hickory Creek \#2 (HC-2)}

Lithic debris $(n=10,381)$ is abundant throughout the archeological deposits at the Hickory Creek site (see Table 2), particularly in Unit 4 in Area A at the southern end of the site (see Figure 2). A variety of raw materials are represented in the lithic debris, including local petrified wood, quartzite, and Glover quartzite, as well as ferruginous sandstone, along with a variety of cherts (most of non-local origin), Manning Fused Glass (see Brown 1976), and quartz (Table 16).

Table 16. Raw materials represented in the lithic debris from excavation levels by Unit.

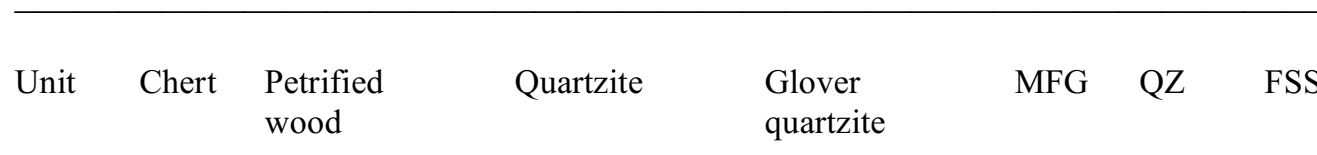

\begin{tabular}{llllllll}
\hline Area A & & & & & & & \\
& & & & & & & \\
1 & $36.0^{*}$ & 48.8 & 10.2 & 4.8 & 0.1 & 0.1 & 0.1 \\
2 & 28.3 & 47.4 & 17.1 & 7.3 & - & - & - \\
3 & 20.7 & 39.0 & 27.4 & 12.9 & - & - & - \\
4 & 21.8 & 43.0 & 20.0 & 11.4 & - & - & 0.1
\end{tabular}

Area B

$\begin{array}{llllllll}5 & 42.5 & 37.1 & 9.1 & 11.3 & - & - & - \\ 6 & 22.9 & 50.9 & 16.4 & 9.6 & - & - & 0.3 \\ 7 & 15.2 & 50.4 & 23.9 & 10.5 & - & - & -\end{array}$

*percentage; $\mathrm{MFG}=$ Manning Fused Glass; $\mathrm{QZ}=$ quartz; $\mathrm{FSS}=$ ferruginous sandstone

In general, the two preferred lithic raw materials in the lithic debris from the Hickory Creek \#2 site are petrified wood and chert in Area A, and petrified wood, chert, and quartzite in Area B (see Table 16). Petrified wood is the most abundant lithic debris in all units except for Unit 5 in Area B, and in several instances, petrified wood outnumbers chert by more than a 2:1 ratio. Chert is most abundant in Units 1 and 5, while quartzite (orthoquartzite and metaquartzite) is best represented in the lithic debris from 
Units 3 and 4 in Area A and Unit 7 in Area B. Glover quartzite is consistently represented by $4.8-12.9 \%$ of the lithic debris regardless of the site area (although it is not well represented by chipped stone tools), and Manning Fused Glass, quartz, and ferruginous sandstone lithic debris are very sparse (see Table 16). By unit and by similarities in the proportions of different raw materials, the units with the most similar lithic debris raw material assemblages are Unit 1 and 2; Units 3 and 4; and Units 6 and 7; Unit 5 stands on its own because of the very limited evidence for the knapping of chert.

At the Hargrove Lake site, occupied in Woodland and Late Caddo times, the lithic debris assemblage in its raw material composition is quite comparable to Unit 7 at the Hickory Creek \#2 site. There, petrified wood accounts for $54 \%$ of the lithic debris, $24 \%$ of the lithic debris is quartzite, $13.8 \%$ are Glover quartzite (Jurney [2000:53] calls this a white quartzite), and only $7.6 \%$ of the lithic debris is chert (Jurney 2000:53).

There appear to be temporal trends in the use of lithic raw materials from one part of the Hickory Creek site to another (Table 17), as seen in the lithic debris. Various cherts were preferentially reduced for chipped stone tool manufacture in the upper Caddo deposits in Units 1 and 2 in Area A, while otherwise chert use was more common in the lower and earlier Woodland and Late Archaic archeological deposits elsewhere on the site (Unit 7 was only excavated through level 3, so temporal trends are not evident in those excavations).

Table 17. Levels with the highest proportion of the different lithic raw materials in the lithic debris.

\begin{tabular}{|c|c|c|c|c|c|c|c|}
\hline Unit & Chert & $\begin{array}{l}\text { Petrified } \\
\text { wood }\end{array}$ & Quartzite & $\begin{array}{l}\text { Glover } \\
\text { quartzite }\end{array}$ & MFG & QZ & FSS \\
\hline \multicolumn{8}{|c|}{ Area A } \\
\hline 1 & $\begin{array}{l}\text { lv. } 6 \\
\text { lv. } 9\end{array}$ & $\begin{array}{l}\text { lv. } 4 \\
\text { lv. } 8\end{array}$ & lv. 3, lv. 5 & lv. $1,1 \mathrm{v} .7$ & $\operatorname{lv.} 1^{*}$ & $\operatorname{lv} .2 *$ & lv. $5^{*}, 1 \mathrm{l} .7^{*}$ \\
\hline 2 & $\begin{array}{l}\text { lv. } 1 \\
\text { lv. } 8\end{array}$ & $\begin{array}{l}\text { lv. } 4 \\
\text { lv. } 7\end{array}$ & lv. 1, lv. 3 & lv. $4,1 \mathrm{v} .7$ & - & - & lv. $6^{*}$ \\
\hline 3 & $\begin{array}{l}\text { lv. } 2 \\
\text { lv. } 5\end{array}$ & $\begin{array}{l}\text { lv. } 4 \\
\text { lv. } 6\end{array}$ & lv. $6,1 \mathrm{l} .7$ & lv. $3,1 v .5$ & - & - & - \\
\hline 4 & $\begin{array}{l}\text { lv. } 7 \\
\text { lv. } 8\end{array}$ & $\begin{array}{l}\text { lv. } 8 \\
\text { lv. } 9\end{array}$ & lv. 3, lv. 5 & lv. 4, lv. 6 & - & - & $\operatorname{lv} .5^{*}$ \\
\hline Area $\mathrm{E}$ & & & & & & & \\
\hline 5 & $\begin{array}{l}\text { lv. } 7 \\
\text { lv. } 9\end{array}$ & $\begin{array}{l}\text { lv. } 4 \\
\text { lv. } 8\end{array}$ & lv. 2, lv. 6 & lv. $2,1 \mathrm{v} .3$ & - & - & - \\
\hline 6 & $\begin{array}{l}\text { lv. } 6 \\
\text { lv. } 7\end{array}$ & $\begin{array}{l}\text { lv. } 4 \\
\text { lv. } 7\end{array}$ & lv. 1, lv. 2 & lv. $3,1 v .8$ & - & - & lv. 6 \\
\hline 7 & lv. 3 & lv. 2 & lv. 1 & lv. 2 & - & - & - \\
\hline
\end{tabular}

*one piece of lithic debris only 
With the exception of Unit 4, where petrified wood was most frequently knapped only in the lower archeological deposits, in other parts of the Hickory Creek site, there is a bimodal peak in its use in both Area A and B excavations. There is a similar bimodal peak in the use of Glover quartzite in Units 1,2, and 4 in Area A and in Unit 6 in Area B (see Table 17), and in the knapping of quartzite in Unit 6. Otherwise, the highest relative frequencies of quartzite lithic debris at the site are to be found in the upper archeological deposits. In the area with the most concentrated Caddo material culture remains (Unit 3), however, the most common use of quartzite for chipped stone tool manufacture was in the lower and earlier archeological deposits.

Manning Fused Glass and quartz are present only in the upper Caddo deposits in Area A. Ferruginous sandstone, on the other hand, is represented in the lower Woodland and Late Archaic archeological deposits, although its use for chipped stone tool manufacture was minimal (see Table 17).

\section{$\mathrm{HC}-3$}

There are 277 pieces of lithic debris from site HC-3, dominated by chert raw materials $(n=147,53 \%)$ from Trinity and Neches River gravel sources; the use of chert is much higher at HC-3 than it is in the archeological deposits at the Hickory Creek \#2 site. Petrified wood is well represented $(n=90,32.5 \%)$, and there are also quartzite $(n=29$, $10.5 \%)$, Glover quartzite $(n=7,2.5 \%)$, ferruginous sandstone $(n=3,1.1 \%)$, and Manning Fused Glass $(n=1,0.4 \%)$. Cherts and petrified wood are the principal raw materials represented in the lithic debris throughout the archeological deposit, and petrified wood is most frequent in the lower depths (below $50 \mathrm{~cm} \mathrm{bs),} \mathrm{where} \mathrm{it} \mathrm{comprises} 43 \%$ of the lithic debris; at those same depths, chert lithic debris accounts for $49 \%$ of the samples by levels. The highest use of chert raw materials is between $20-30 \mathrm{~cm}$ bs (70\%) and $40-50$ cm bs $(60 \%)$.

\section{Cores}

A total of 31 cores were identified in the lithic debris from the Hickory Creek \#2 site. These are from pebbles and cobbles of available lithic raw materials (Figure 34a-c), including petrified wood $(n=10,32.3 \%)$, quartzite $(n=9,29.0 \%)$, Glover quartzite $(n=7$, $22.6 \%)$, and chert $(n=5,16.1 \%)$. By depth, $90 \%$ of the cores were recovered from $40-80$ $\mathrm{cm}$ bs, including all of the chert and Glover quartzite cores, and only three cores (two of quartzite and one of petrified wood) occurred from $0-40 \mathrm{~cm}$ bs. Since lithic debris is abundant in all levels at the site (see Tables 2-4), this suggests that a fundamental change took place in lithic reduction strategies through time. The earlier and primarily Late Archaic and Woodland period lithic reduction strategy was based on the reduction of cores and bifaces to primarily manufacture bifacial tools, while the later Caddo knapping strategy was designed to reduce pebbles and cobbles to obtain usable flakes for chipped stone tools, including arrow points and various formal and expedient flake tools. 


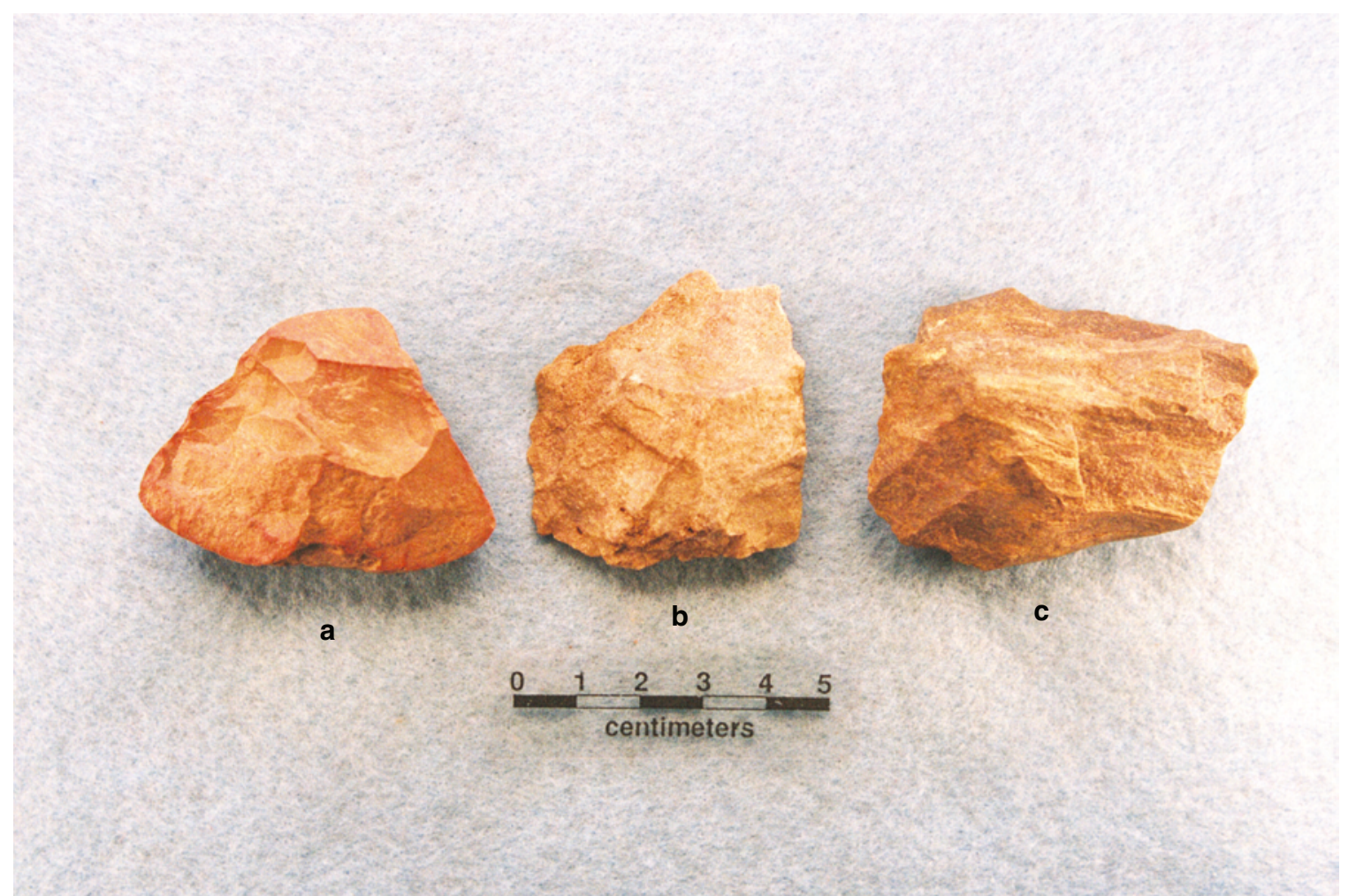

Figure 34. Selected cores from the Hickory Creek \#2 site: a, quartzite; $\mathbf{b}$, Glover quartzite; c, petrified wood. Provenience: a, Unit 4A, 50-60 cm bs; b, Unit 4, 40-50 cm bs; c, Unit 6, 30-40 cm bs.

\section{Ground Stone tools}

\section{$41 \mathrm{HO} 13$}

The one ground stone tool from $41 \mathrm{HO} 13$ (Unit 1, 110-120 cm bs) is a fragment of a mano or grinding stone made from a dense and locally available quartzite cobble.

\section{Hickory Creek \#2 (HC-2)}

The excavations at the Hickory Creek \#2 site recovered 18 ground stone tools or pigment stones. One of the pigment stones came from a Looter back dirt pile, but the other 17 ground stone implements are concentrated in the lower and older archeological deposits $(50-90 \mathrm{~cm}$ bs). This comprises $82.4 \%(n=14)$ of the ground stone tools, including two pigment stones (Figure 35), two quartzite hammerstones, one grinding slab, five pitted stones, two manos, and a petrified wood axe or celt fragment (from 70-80 $\mathrm{cm} \mathrm{bs)}$ 


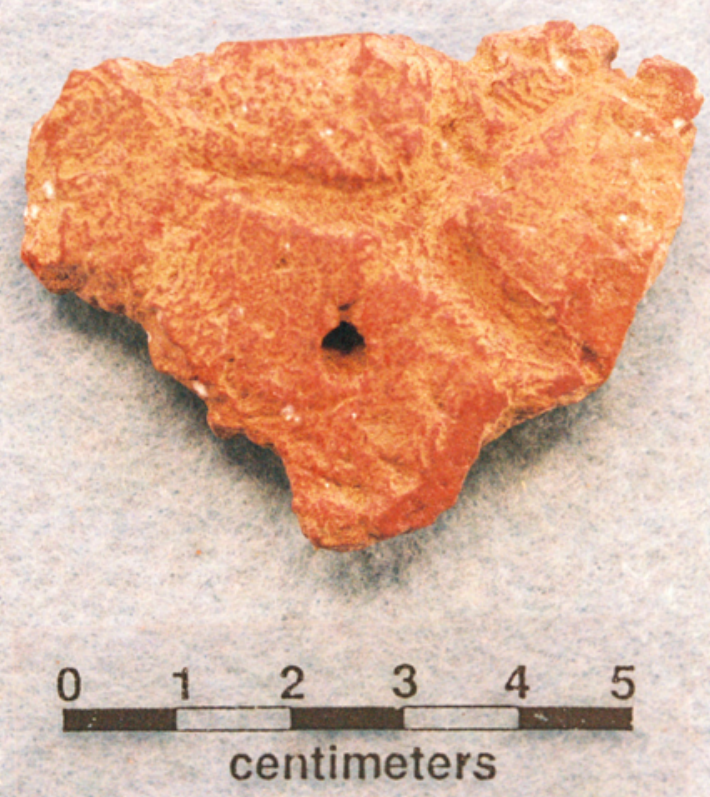

Figure 35. Pigment stone with a drilled hole from Unit 1, 50-60 cm bs, at the Hickory Creek \#2 site.

There are only three ground stone implements in the upper Caddo archeological deposits. They include a pitted stone from $20-30 \mathrm{~cm}$ bs, a ochre chunk from $30-40 \mathrm{~cm}$ bs, and a mano made from Catahoula sandstone.

\section{HC-3}

There are two ground stone tools from this site, both from below $50 \mathrm{~cm}$ bs. One is a quartzite hammerstone $(60-70 \mathrm{~cm} \mathrm{bs})$, and the other is a quartzite mano fragment (50$60 \mathrm{~cm} \mathrm{bs})$.

\section{Fire-cracked rock}

Fire-cracked rocks $(n=78)$ of locally available quartzite and ferruginous sandstone are present in the archeological deposits at the Hickory Creek \#2 site (see Tables 2-3). The highest densities (1.9-2.8 fire-cracked rocks per square meter) are in Units 1, 4, and 6 , and in the lowermost archeological deposits (see Table 4).

\section{Animal Bones}

Animal bones are preserved in the archeological deposits at the Hickory Creek \#2 site, although not in great quantities (Table 18). These remains have yet to be analyzed or identified by species or body part by a zooarcheologist. 
Table 18. Distribution of animal bone by provenience and depth at the Hickory Creek \#2 site.

\begin{tabular}{|c|c|c|c|}
\hline Provenience & Depth (cm bs) & No. & Percentage \\
\hline Unit 1 & $0-10$ & 3 & 0.9 \\
\hline Unit 1 & $10-20$ & 9 & 2.7 \\
\hline Unit 1 & $20-30$ & 15 & 4.5 \\
\hline Unit 1 & $30-40$ & 19 & 5.7 \\
\hline Unit 1 & $40-50$ & 7 & 2.1 \\
\hline Unit 1 & $50-60$ & 7 & 2.1 \\
\hline Unit 1 & $60-70$ & 3 & 0.9 \\
\hline Unit 1 & $80-90$ & 3 & 0.9 \\
\hline Unit 2 & $10-20$ & 1 & 0.3 \\
\hline Unit 2 & $30-40$ & 1 & 0.3 \\
\hline Unit 2 & $40-50$ & 1 & 0.3 \\
\hline Unit 3/3A & $10-20$ & 41 & 12.3 \\
\hline Unit 3/3A & $20-30$ & 47 & 14.1 \\
\hline Unit 3 & $30-40$ & 73 & 21.9 \\
\hline Unit 3 & $40-50$ & 36 & 10.8 \\
\hline Unit 4 & $0-10$ & 2 & 0.6 \\
\hline Unit 4 & $10-20$ & 6 & 1.8 \\
\hline Unit 4/4A & $20-30$ & 3 & 0.9 \\
\hline Unit 4 & $40-50$ & 2 & 0.6 \\
\hline Unit 4/4A & $50-60$ & 12 & 3.6 \\
\hline Unit 4A & $70-80$ & 5 & 1.5 \\
\hline Unit 4A & $80-90$ & 7 & 2.1 \\
\hline Unit 5 & $60-70$ & 1 & 0.3 \\
\hline Unit 6 & $0-10$ & 2 & 0.6 \\
\hline Unit 6 & $10-20$ & 4 & 1.2 \\
\hline Unit 6 & $20-30$ & 4 & 1.2 \\
\hline Unit 6 & $30-40$ & 1 & 0.3 \\
\hline Unit 6 & $50-60$ & 2 & 0.6 \\
\hline Unit 6 & $60-70$ & 2 & 0.6 \\
\hline Unit 7 & $10-20$ & 2 & 0.6 \\
\hline \multirow[t]{3}{*}{ All units } & $0-10$ & 7 & 2.1 \\
\hline & $10-20$ & 63 & 18.9 \\
\hline & $20-30$ & 69 & 20.7 \\
\hline
\end{tabular}


Table 18. Distribution of animal bone by provenience and depth at the Hickory Creek \#2 site, cont.

\begin{tabular}{llll}
\hline \multirow{2}{*}{ Provenience } & Depth $(\mathrm{cm} \mathrm{bs})$ & No. & Percentage \\
& & & \\
\hline All units, & $30-40$ & 94 & 28.2 \\
cont. & $40-50$ & 46 & 13.8 \\
& $50-60$ & 21 & 6.3 \\
& $60-70$ & 6 & 1.8 \\
& $70-80$ & 5 & 1.5 \\
& $80-90$ & 10 & 3.0 \\
LP 3 & - & 5 & 1.5 \\
LP 4 & - & 1 & 0.3 \\
LP 5 & - & 3 & 0.9 \\
LP 8 & - & 4 & 1.2 \\
& & & \\
Totals & & 334 & \\
\end{tabular}

By depth, the highest densities of animal bone at the Hickory Creek \#2 site are between 10-50 $\mathrm{cm}$ bs (see Table 18), particularly the 30-40 cm (31\%) and 20-30 cm (22\%) levels, especially in Area A. The density of animal bone closely correlates with the other kinds of prehistoric Caddo archeological materials recovered in the excavations (see Table 4), as $61.4 \%$ of the animal bone is from Unit $3 ; 20.6 \%$ of the animal bone is from Unit 1.

\section{Charred Plant Remains}

Although not studied or quantified in this analysis, charred plant remains are present at the Hickory Creek \#2 site (HC-2). This includes wood charcoal and charred nutshells, most likely from hickory (Carya sp.) nuts. 


\section{NATURE AND AGE OF THE PREHISTORIC COMPONENTS AT THE FOUR SITES}

The archeological investigations at $41 \mathrm{HO} 13$ and $\mathrm{HC}-1$ by the U.S. Forest Service were so limited as to preclude any reasonable speculation about the occupational nature of either site. The recovered dart points, arrow points, and pottery from the two sites, however, suggest that they were primarily occupied during the Woodland period (ca. 500 B.C to A.D. 800), although one incised-punctated decorated sherd from HC-1 is indicative of an occupation sometime after ca. A.D. 800 by the prehistoric ancestors of the Caddo Indian peoples.

The principal, if not the sole, archeological component at HC-3 appears to be a Woodland period occupation that dates after ca. A.D. 200. During the use of the site by prehistoric Woodland groups of the inland Mossy Grove Culture (see Story 1990; Perttula 2008:Figure 12-2), the principal activities that are preserved in the archeological record there include hunting, plant food gathering/processing with chipped and ground stone tools, hot rock cooking of foodstuffs as well as the cooking (i.e., boiling food stuffs) in sandy paste pottery vessels, and the knapping of chipped stone tools. The presence of ceramics at HC-3 hints at the beginnings of a more settled way of life, as the manufacture and use of ceramic vessels for cooking, storage, and food-serving implies that more extended stays may have occasionally taken place at the site, perhaps during the latter part (after ca. A.D. 500-600) of the Woodland period (Perttula 2008:675). No mention of midden deposits or features in the limited HC-3 excavations suggests that these stays by Woodland period groups are likely the product of a tethering of these groups to certain locations (within the Pineywoods exclusively?) and a repeated and consistent use of these locations by mobile hunter-gatherers.

The prehistoric use of the Hickory Creek \#2 site is considerably more complex temporally than the other Hickory Creek sites, either because it was a favorable location and landform setting for repeated and redundant use, or more likely it is because considerably more extensive excavations were completed here by the NFGT in the 2006 and 2007 PIT projects, thus resulting in the recovery of a diverse range of stone and ceramic artifacts. The recovered artifacts from the site indicate that it was used for activities where artifacts were discarded during the Paleoindian, Middle Archaic, Late Archaic, Woodland (Mossy Grove), Early Caddo, $14^{\text {th }}$ to early $15^{\text {th }}$ century Middle Caddo, and Late Caddo ( $16^{\text {th }}$ to mid- $17^{\text {th }}$ century) periods. The principal occupations at the site (i.e., the occupations that resulted in the most substantial accumulation of archeological materials) occurred first in the Woodland period (ca. A.D. 200-700), and then a number of centuries later by Caddo peoples in the $14^{\text {th }}$ to early $15^{\text {th }}$ century A.D.

There are spatial differences in the use of the Hickory Creek \#2. In Area A at the western part of the site (see Figure 2), there is evidence for prehistoric use during the Middle Archaic, Late Archaic, Woodland, and Early Caddo periods, and then again during the $14^{\text {th }}$ and early $15^{\text {th }}$ centuries A.D. There are dense accumulations of both Woodland and Middle Caddo archeological materials in this area-much denser here than elsewhere at the site-such that it seems clear that Area A was the scene of several extended stays during the latter part of the Woodland period (ca. A.D. 200-700) as well 
as the locus of a Middle Caddo domestic occupation. It is suspected that there is at least one farmstead compound in Area A (in the immediate vicinity of Unit 3). The Woodland period component in this area contains evidence for hunting, plant food gathering/processing with chipped and ground stone tools, hot rock cooking of foodstuffs as well as the cooking (i.e., boiling food stuffs) in sandy paste pottery vessels, and the knapping of chipped stone tools (particularly Gary and Kent dart points). The knapping of chipped stone arrow points (Perdiz) and flake tools was also important during the Middle Caddo component in Area A, as was the manufacture and use of a domestic ceramic assemblage comprised of cooking jars, bottles, and serving vessels (the latter early forms of Poynor Engraved). These Caddo peoples also made and used longstemmed Red River style clay pipes. The Middle Caddo component in Area A contains a moderate density of preserved faunal remains.

Temporally diagnostic lithic and/or ceramic artifacts from Area B (see Figure 2) in the eastern part of the site testify to aboriginal use during Paleoindian, Middle Archaic, Late Archaic, Woodland, and Late Caddo periods. The Woodland (Gary and Kent dart points and plain sandy paste pottery sherds) and the Late Caddo (Perdiz arrow points, later Poynor Engraved styles, elbow pipe sherds) occupations were the most substantial that occurred in Area B, suggesting a relatively intensive use for habitation and various domestic-related activities (at least by comparison with the Paleoindian and Archaic components; Middle and Late Archaic dart points are proportionally more abundant in Area B than they are in Area A), but nowhere comparable in apparent intensity and/or duration of use as the Woodland and Middle Caddo occupations in Area A at the Hickory Creek \#2 site.

One interesting aspect of the archeological record at the Hickory Creek \#2 site is the intriguing possibility that it contains discrete Middle and Late Caddo archeological deposits stratified above a deeper archeological zone (ca. 40-90 cm bs) that almost exclusively has Woodland period dart points, tools, and sandy paste Goose Creek Plain and decorated pottery. Although there is no available information on the likely depositional context of these upper and lower materials, the fact that the archeological deposits at the site occur on an alluvial rise in the Hickory Creek valley leaves open the possibility that there were periods of sediment accumulation at the site that could have led to the gradual burial of Woodland period and earlier archeological materials prior to the occupation of the site again in the $14^{\text {th }}$-early $15^{\text {th }}$ and $16^{\text {th }}$-mid- $17^{\text {th }}$ centuries by Caddo peoples.

\section{RECOMMENDATIONS FOR FUTURE ARCHEOLOGICAL INVESTIGATIONS AND ARTIFACT ANALYSES}

It is fair to state that the NFGT archeological investigations at $41 \mathrm{HO} 13, \mathrm{HC}-1$, HC-3, and the Hickory Creek \#2 sites on Hickory Creek in Houston County, Texas, have

barely tapped their research potential with respect to gaining a better understanding of the native history of this locale in the East Texas Pineywoods. Even the present analyses of the recovered prehistoric artifacts from the site represent only a cursory examination of their technological, functional, and stylistic character, and could be much improved with 
more detailed contextual information on the archeological deposits at each of the sites, most particularly the archeological deposits at the Hickory Creek \#2 site. There are several recommendations we offer concerning future archeological investigations and artifact analyses that should be completed at these sites, first to permit NFGT to complete formal determinations of the eligibility of the sites for inclusion in the National Register of Historic Places (NRHP), and second to better realize the research value of the preserved archeological deposits and associated material culture remains found at each of the sites.

With respect to analyses of the existing artifact samples from the four prehistoric sites on Hickory Creek, we recommend the following:

1. The preserved faunal remains from the Hickory Creek \#2 site should be analyzed by a zooarcheologist familiar with Caddo faunas for species identifications, minimum number of individuals, presence of bone tools, etc., and by area and depth. It is thought that the majority of the faunal remains are from the $14^{\text {th }}$-early $15^{\text {th }}$ and $16^{\text {th }}$-mid- $17^{\text {th }}$ century Caddo occupations in Areas A and B, respectively, and thus these preserved remains have the potential to shed light on game animal procurement patterns of the Caddo inhabitants over time.

2. Charred plant remains, including wood charcoal and nutshells, and possibly other types of plant remains, should be fully analyzed, by area and depth, by a paleobotanist familiar with the range of plant remains likely preserved in East Texas Woodland and Caddo sites. Cultivated plants may be preserved in the recovered samples. If there are soil samples recovered from the 2006 and 2007 investigations, they should be processed by fine-screening (1/16-inch mesh) or flotation (depending upon their context) to recover additional charred plant remains from controlled contexts, and also assess the suitability of any charred plant remain concentrations for future AMS radiocarbon analyses.

3. The lithic and ceramic artifacts from the 2006 and 2007 investigations (see Table 1) at the four Hickory Creek sites should receive detailed analyses of their technological, functional, and stylistic character, by area and depth, with the purpose of refining the analyses presented in this report, and grounded in a better understanding of their depositional contexts (see below). Such new analyses would illuminate the manufacture, use, and discard of chipped and ground stone tools from the different prehistoric components at the four sites, but the processes whereby Woodland and Caddo ceramic vessels and clay pipes were made, tempered, fired, and decorated in a more refined manner than could be attempted herein. The instrumental neutron activation analysis (INAA) of key Woodland and Caddo ceramic sherds and local clay samples, would provide important chemical compositional data for comparison with the emerging Caddo INAA database, of more than 1000 sherds and clay samples, to assess the manufacturing locales of the ceramic vessels.

In our opinion, the four Hickory Creek sites warrant additional archeological investigations for very specific reasons: 
1. These investigations, when done through the preparation and implementation of an acceptable research design that specifies regionally relevant research problems that the archeological data from the sites can address, and also specifies the methods and techniques to be employed to collect the necessary archeological data, should be sufficient to allow the NFGT, the Texas State Historic Preservation Office, the Caddo Nation of Oklahoma, and any interested parties to consult to complete NRHP eligibility determinations for each of the sites.

2. Key to the success of future archeological investigations at the Hickory Creek sites is a thorough geoarcheological study to determine the depositional context of the archeological deposits and associated landforms at each of the sites, and determine through coring and down-hole magnetic susceptibility analysis (cf. Dalan 2006:168-170) of cores or boreholes, and establish the likelihood that the sites (particularly the Hickory Creek \#2 site) have the potential to contain stratified archeological deposits and have the potential to contain preserved archeological features or intact concentrations of archeological remains.

3. To better clarify the horizontal and vertical stratigraphy of the Woodland and $14^{\text {th }}$ early $15^{\text {th }}$ century Caddo archeological materials in the immediate vicinity of Unit 3 in Area 3, new excavations should be undertaken there that follow recognized soil sediment zones, or employ close interval (5 cm thick) arbitrary levels within sediment zones. The purpose of this work would also be facilitated by the careful collection of elevation data from all flat-lying artifacts in the excavations. These new excavations would also serve the purpose of ascertaining the functional character of the dense concentration of Caddo ceramic sherds and animal bones in the upper $40 \mathrm{~cm}$ of the archeological deposit, and establish with confidence if these remains occur in association with a preserved Caddo domestic structure.

4. The HC-3 site, on the basis of a single $1 \times 1 \mathrm{~m}$ unit, appears to be a single component Woodland period component dated from ca. A.D. 200-700. A larger excavation carried out in the future at the site, comparable to the excavations in Area A at the Hickory Creek \#2 site and carried out in the same manner as described in No. 3 above, should be sufficient to establish if the site does have an intact single component Woodland period occupation. If this could be demonstrated, in conjunction with establishing that the archeological deposits have the potential to contain: (a) preserved archeological features, (b) preserved faunal and floral remains, and (c) datable organic materials or ceramic sherds (through TL/OSL or rehydroxylation [Wilson et al. 2009]), the new knowledge that would be gained about the archeology of the Woodland period in East Texas would be significant.

5. The recommended future careful excavations at the Hickory Creek \#2 and HC-3 sites (as well as $41 \mathrm{HO} 13$ and $\mathrm{HC}-1$, if deemed warranted by the consulting parties) should also be geared towards the collection of multiple samples of datable materials from controlled contexts. This would the AMS dating of organic remains from key buried contexts, TL/OSL dating of ceramic sherds recovered in situ from different depths and sediment zones, and the dating of ceramic sherds from different depths and sediment zones through determining their rehydroxylation rates. 
6. Recovered lithic and ceramic artifacts from future investigations at the Hickory Creek sites should receive detailed analyses of their technological, functional, and stylistic character, by area and depth. Such new analyses would illuminate the manufacture, use, and discard of chipped and ground stone tools from the different prehistoric components (well-grounded in time through the analyses of samples outlined in No. 5 above) at the sites, as well the processes whereby Woodland and Caddo ceramic vessels and clay pipes were made, tempered, fired, and decorated in a more refined manner than could be attempted herein. Additional INAA of key Woodland and Caddo ceramic sherds and local clay samples, would provide important chemical compositional data to assess the manufacturing locales of the ceramic vessels. Charred plant remains and faunal remains recovered in this work from controlled depths and feature contexts should be analyzed in detail to illuminate Woodland and prehistoric Caddo use of plant foods and game animals.

7. The archeological research findings from these proposed future investigations should be presented in a comprehensive and well-illustrated technical report that is made available to the Texas State Historic Preservation Office, the Caddo Nation of Oklahoma, interested parties, and interested members of the public. The findings from the Hickory Creek sites should be synthesized for comparison with other relevant prehistoric sites in the East Texas Pineywoods.

We also think it would be appropriate for the NFGT to devise and conduct intensive archeological survey investigations of a broader segment of the Hickory Creek valley on Forest Service lands. This work would be geared to identifying additional sites associated with the clusters of Woodland period and $14^{\text {th }}$-early $15^{\text {th }}$ and $16^{\text {th }}-$ mid- $17^{\text {th }}$ century Caddo settlements already known in the valley.

Finally, as previously mentioned, several of the Hickory Creek sites - most notably the Hickory Creek \#2 site - have been damaged by looters and artifact collectors. Consequently, we recommend that the NFGT develop protection plans for all important prehistoric sites on NFGT lands along Hickory Creek that specify how the sites will be regularly monitored to insure that no further looting is done at them, and what steps will be taken to protect the sites over the long-term. 


\section{END NOTES}

1. At the present time, the U.S. Forest Service (National Forests and Grasslands in Texas) have not obtained site trinomials for the HC-1, Hickory Creek \#2 (HC-2), and HC-3 sites.

2. Information is not available from the NFGT on the location of the looter pits relative to the excavation units, or on the extent and depth of the looter pits.

3. The radiocarbon sample form and Beta Analytic, Inc. results form are not available from the NFGT, but the $510 \pm 40$ B.P. date was written down by Barbara J. Williams, and communicated to us in an e-mail. We assume that this date is the conventional radiocarbon age rather than the calibrated age range.

4. An apt comparison of $\mathrm{P} / \mathrm{DR}$ ratios with that of the Hickory Creek \#2 site would have been provided by the nearby Hargrove Lake site (41HO150). Unfortunately, Jurney (2000:54-66) does not provide any sort of comprehensive tabulation of the number of plain or decorated sherds in the body of the report or in the report appendices.

5. The location of the Looter Pits on the Hickory Creek \#2 site are not known, and thus the provenience of the dart points from Looter Pits 3, 4, and 8 is also not known. The points from looter pits include four tips/blade fragments, one Gary point, one parallelstemmed/flat-based form, one Dawson point, and one Morrill.

\section{ACKNOWLEDGMENTS}

We would like to thank Barbara Williams (U.S. Forest Service, National Forests $\&$ Grasslands in Texas, Lufkin) for facilitating this study, and for providing the opportunity to wok on these important collections from the Hickory Creek sites. Mark Walters provided comments on an earlier draft version of this report. Bo Nelson took the photographs of the artifacts used in this report. Sandra Hannum prepared the map of the Hickory Creek \#2 site.

\section{REFERENCES CITED}

Aten, L, E. and C. N. Bollich

2002 Late Holocene Settlement in the Taylor Bayou Drainage Basin: Test Excavations at the Gaulding Site (41JF27), Jefferson County, Texas. Studies in Archeology 40, Texas Archeological Research Laboratory, The University of Texas at Austin, and Special Publication No. 4, Texas Archeological Society, San Antonio.

Bever, M. R. and D. J. Meltzer

2007 Exploring Variation in Paleoindian Life Ways: The Third Revised Edition of the Texas Clovis Fluted Point Survey. Bulletin of the Texas Archeological Society 78:65-99. 
Brown, I. W.

1998 Decorated Pottery of the Lower Mississippi Valley: A Sorting Manual. Mississippi Archaeological Association and Mississippi Department of Archives and History, Jackson.

Brown, K. M.

1976 Fused Volcanic Glass from the Manning Formation. Bulletin of the Texas Archeological Society 47:189-207.

Cliff, M. B. and T. K. Perttula

2002 Results of National Register Investigations Conducted on Site 41PN175, Panola County, Texas. Report No. 32. Archeological Studies Program, Texas Department of Transportation, Austin.

Dalan, R. A.

2006 Magnetic Susceptibility. In Remote Sensing in Archaeology: An Explicitly North American Perspective, edited by J. K. Johnson, pp. 161-203. University of Alabama Press, Tuscaloosa.

Diggs, G. M., Jr., B. L. Lipscomb, M. D. Reed, and R. J. O’Kinnon

2006 Illustrated Flora of East Texas. Botanical Research Institute of Texas, Fort Worth.

Ensor, H. B. and D. L. Carlson (editors)

1991 Alabonson Road: Early Ceramic Period Adaptation to the Inland Coastal Prairie Zone, Harris County, Southeast Texas. Reports of Investigations No. 8. Archeological Research Laboratory, Texas A\&M University, College Station.

Fields, R. C.

1995 Analysis of Native-Made Ceramics. In The Deshazo Site, Nacogdoches County, Texas, Volume 2: Artifacts of Native Manufacture, edited by D. A. Story, pp. 173232. Studies in Archeology 21. Texas Archeological Research Laboratory, The University of Texas at Austin.

Gadus, E. F. and R. C. Fields

1997 Test Excavations at 41WA185, Walker County, Texas. Technical Reports, No. 25. Prewitt and Associates, Inc., Austin.

Girard, J. S.

1995 The Chipped Stone Collection: Technological, Functional, and Typological Analyses. In The Deshazo Site, Nacogdoches County, Texas, Vol. 2, edited by D. A. Story, pp. 33-156. Studies in Archeology 21. Texas Archeological Research Laboratory, The University of Texas at Austin. 
Greaves, R. D.

2002 Archaeological Survey of Huntsville State Park and Excavations in 41WA47, Walker County, Texas. Archaeological Survey Report, No. 327. Center for Archaeological Research, The University of Texas at San Antonio.

Hoffman, M. P.

1967 Ceramic Pipe Style Chronology Along the Red River Drainage in Southwestern Arkansas. The Arkansas Archeologist 8(1):4-14.

Jelks, E. B.

1965 The Archeology of McGee Bend Reservoir. Ph.D. dissertation, Department of Anthropology, The University of Texas at Austin.

Jurney, D. H.

2000 Archaeological Investigations at the Hargrove Lake Site (41HO150), Davy Crockett National Forest, Houston County, Texas: 1997 Season. United States Department of Agriculture, Forest Service, Lufkin, Texas.

McClurkan, B. B.

1968 Livingston Reservoir, 1965-66: Late Archaic and Neo-American Occupations. Papers No. 12. Texas Archeological Salvage Project, The University of Texas at Austin.

Meltzer, D. J.

1986 The Clovis Paleoindian Occupation of Texas: Results of the Texas Clovis Fluted Point Survey. Bulletin of the Texas Archeological Society 57:27-68.

Meltzer, D. J. and M. R. Bever

1995 Paleoindians of Texas: An Update on the Texas Clovis Fluted Point Survey. Bulletin of the Texas Archeological Survey 66:17-51.

Newell, H. P. and A. D. Krieger

2000 The George C. Davis Site, Cherokee County, Texas. $2^{\text {nd }}$ Edition. Society for American Archaeology, Washington, D.C.

Perttula, T. K.

2004 The Prehistoric and Caddoan Archeology of the Northeastern Texas Pineywoods. In The Prehistory of Texas, edited by T. K. Perttula, pp. 370-407. Texas A\&M University Press, College Station.

2008 Trends and Varieties in Late Caddo and Historic Caddo Fine Ware Pottery Types in the Upper Neches River Basin. Journal of Northeast Texas Archaeology 28:5155. 
2009 The Ceramic Artifacts from the Lang Pasture Site (41AN38) and the Place of the Site within an Upper Neches River Basin Caddo Ceramic Tradition. In Archeological Investigations at the Lang Pasture Site (41AN38) in the Upper Neches River Basin of East Texas, assembled and edited by T. K. Perttula and D. B. Kelley, pp. 6-1 to 6-260. Coastal Environments, Inc., Baton Rouge.

Perttula, T. K. (editor)

2008 Lake Naconiche Archeology, Nacogdoches County, Texas. Results of the Data Recovery Excavations at Five Prehistoric Archeological Sites. 2 Vols. Report of Investigations No. 60. Archeological \& Environmental Consultants, LLC, Austin.

Perttula, T. K. and B. Nelson

2003 The Nawi haia ina Site (41RK170): Archeological Investigations in the City of Henderson's Southside Wastewater Treatment Plant, Rusk County, Texas. Report of Investigations No. 51. Archeological \& Environmental Consultants, LLC, Austin.

2004 Woodland and Caddo Archeology at the Broadway or Kanduts'ah Kuhnihdahahdisa' Site (41SM273) on the City of Tyler-Lake Palestine WTP Project, Smith County, Texas. Report of Investigations No. 50. Archeological and Environmental Consultant, LLC, Austin.

2006 Test Excavations at Three Caddo Sites at Mission Tejas State Park, Houston County, Texas. Report of Investigations No. 76. Archeological \& Environmental Consultants, LLC, Austin.

Perttula, T. K., L. L. Bush, L. Schniebs, T. Middlebrook, and P. S. Marceaux 2009 An Early Historic Caddo Farmstead at the Henry M. Site (41NA60) in Nacogdoches County, Texas. MS on file, Department of Sociology, Anthropology, and Social Work, Stephen F. Austin State University, Nacogdoches.

Philips, P.

1970 Archaeological Survey in the Lower Yazoo Basin, Mississippi, 1949-1955. Papers of the Peabody Museum of Archaeology and Ethnology 60. Harvard University, Cambridge.

Prewitt, E. R.

2005 Review of The Prehistory of Texas, edited by T. K. Perttula. Bulletin of the Texas Archeological Society 76:266-277.

Reimer, P. J., M. G. L. Baillie, E. Bard, A. Bayliss, J. W. Beck, C. J. H. Bertrand, P. G. Blackwell, C. E. Buck, G. S. Burr, K. B. Cutler, P. E. Damon, R. L. Edwards, R. G. Fairbanks, M. Friedrich, T. P. Guilderson, A. G. Hogg, K. A. Hughen, B. Kromer, F. G. McCormac, S. W. Manning, C. B. Ramsey, R. W. Reimer, S. Remmele, J. R. Southon, M. Stuiver, S. Talamo, F. W. Taylor, J. van der Plicht, and C. E. Weyhenmeyer

2004 IntCal04 Terrestrial Radiocarbon Age Calibration, 26-0 ka BP. Radiocarbon 46:1029-1058. 
Rogers, R., M. A. Nash, and T. K. Perttula

2001 Excavations at the Herman Bellew Site (41RK222), Rusk County, Texas.

Document No. 000021. PBS\&J, Inc., Austin.

Saunders, R. and C. T. Hays

2004 Introduction: Themes in Early Pottery Research. In Early Pottery: Technology, Function, Style, and Interaction in the Lower Southeast, edited by R. Saunders and C. T. Hays, pp. 1-22. University of Alabama Press, Tuscaloosa.

Schambach, F. F.

1982 An Outline of Fourche Maline Culture in Southwest Arkansas. In Arkansas Archeology in Review, edited by N. L. Trubowitz and M. D. Jeter, pp. 132-197. Research Series No. 15. Arkansas Archeological Survey, Fayetteville.

Shafer, H. J.

1973 Lithic Technology at the George C. Davis Site, Cherokee County, Texas. Ph.D. dissertation, Department of Anthropology, The University of Texas at Austin.

2007 Leaning Rock Site (41SM325) Lithics. Caddo Archeology Journal 16:57-70.

2008 A Study of Chipped Stone Artifacts from the Redwine Site (41SM193), Smith County, Texas. Journal of Northeast Texas Archaeology 27:49-75.

Shafer, H. J. and M. Walters

in press The Browning Site (41SM195A) Lithics: Considering Patterns of Identity and Interaction through Lithic Analysis. Bulletin of the Texas Archeological Society 81.

Story, D. A.

1990 Cultural History of the Native Americans. In The Archeology and Bioarcheology of the Gulf Coastal Plain, by D. A. Story, J. A. Guy, B. A. Burnett, M. D. Freeman, J. C. Rose, D. G. Steele, B. W. Olive, and K. J. Reinhard, pp. 163-366. 2 Vols. Research Series No. 38. Arkansas Archeological Survey, Fayetteville.

2000 Introduction. In The George C. Davis Site, Cherokee County, Texas, by H. P. Newell and A. D. Krieger, pp. 1-31. $2^{\text {nd }}$ Edition. Society for American Archaeology, Washington, D.C.

Suhm, D. A. and E. B. Jelks (editors)

1962 Handbook of Texas Archeology: Type Descriptions. Special Publication No. 1, Texas Archeological Society, and Bulletin No. 4, Texas Memorial Museum, Austin.

Thoms, A. V.

2008 The fire stones carry: Ethnographic records and archaeological expectations for hot-rock cookery in western North America. Journal of Anthropological Archaeology 27(4):443-460. 
Trubitt, M. B.

2009 Investigating Middle Archaic at the Jones Mill Site. The Arkansas Archeologist 48:71-84.

Turner, E. S. and T. R. Hester

1999 A Field Guide to Stone Artifacts of Texas Indians. Gulf Publishing and Taylor Trade Publishing, Lanham, Maryland.

Webb, C. H., F. E. Murphey, W. G. Ellis, and H. R. Green

1969 The Resch Site, 41HS16, Harrison County, Texas. Bulletin of the Texas Archeological Society 40:3-106.

Willis, M. D.

2007 Archeological Testing at Site 41PK248 on the Alabama-Coushatta Indian Reservation, Polk County, Texas. Blanton \& Associates, Inc., Austin.

Wilson, M. A., M. A. Carter, C. Hall, W. D. Hoff, C. Ince, S. D. Savage, B. McKay, and I. M. Betts

2009 Dating fired-clay ceramics using long-term power law rehydroxylation kinetics. Proceedings of the Royal Society A:1-9. 


\section{APPENDIX 1,}

\section{INVENTORY OF ARTIFACTS FROM THE HICKORY CREEK \#2 SITE, HC-2}

Unit $1,0-10 \mathrm{~cm}$

Unit $1,10-20 \mathrm{~cm}$

Unit $1,20-30 \mathrm{~cm}$

Unit 1, 30-40 cm

Unit $1,40-50 \mathrm{~cm}$

Unit 1, 50-60 cm
3 animal bones; 2 plain body sherds (1 grog-tempered, 1 bone-tempered); 1 lithic debris, Manning Fused Glass; 8 lithic debris, quartzite; 7 lithic debris, Glover quartzite; 30 lithic debris, chert; 31 lithic debris, petrified wood

9 animal bones; 1 plain grog-tempered body sherd; $1 \mathrm{cf}$. Perdiz-Bonham arrow point, quartzite; 1 arrow point preform, petrified wood; $1 \mathrm{cf}$. Edgewood dart point, chert; 1 biface fragment, petrified wood; 1 lithic debris, quartz; 10 lithic debris, Glover quartzite; 21 lithic debris, quartzite; 68 lithic debris, chert; 81 lithic debris, petrified wood

15 animal bones; 2 punctated grog-tempered body sherds; 1 brushed grog-hematite-tempered body sherd; 3 plain body sherds (2 grog-bone-tempered, 1 grog-tempered); 1 grogtempered base sherd; 2 flake tools, chert; 7 lithic debris, Glover quartzite; 29 lithic debris, quartzite; 70 lithic debris, chert; 106 lithic debris, petrified wood

19 animal bones; 1 brushed grog-tempered body sherd; 1 plain grog-tempered body sherd; 1 plain bone-hematite body sherd; 1 mano, Catahoula sandstone; 10 lithic debris, Glover quartzite; 18 lithic debris, quartzite; 65 lithic debris, chert; 118 lithic debris, petrified wood; 1 fire-cracked rock, ferruginous sandstone; 1 fire-cracked rock, quartzite

7 animal bones; 1 engraved grog-tempered body sherd; 3 plain grog-tempered body sherds; 1 plain sandy paste body sherd; 2 burned clay; 1 Gary dart point, quartzite; 1 Gary dart point, petrified wood; 1 dart point tip, petrified wood; 2 cores, petrified wood; 4 lithic debris, Glover quartzite; 1 lithic debris, ferruginous sandstone; 22 lithic debris, quartzite; 48 lithic debris, chert; 82 lithic debris, petrified wood

7 animal bones; 3 plain grog-tempered body sherds; 4 plain sandy paste body sherds; 1 burned clay; 1 flake tool, chert; 1 ochre pigment stone; 10 lithic debris, Glover quartzite; 83 lithic debris, chert; 17 lithic debris, quartzite; 92 lithic debris, petrified wood; 1 lithic debris, hematite; 3 firecracked rock, quartzite; 1 fire-cracked rock, ferruginous sandstone 
Unit $1,60-70 \mathrm{~cm}$

Unit $1,70-80 \mathrm{~cm}$

Unit 1, 80-90 cm

Unit 2, surface

Unit 2, 0-10 cm
3 animal bones; 3 brushed grog-tempered body sherds; 1 engraved grog-bone-tempered body sherd; 1 plain hematite-tempered rim sherd; 3 plain grog-tempered body sherds; 4 plain sandy paste sherds; 1 Gary dart point, petrified wood; 1 Kent dart point, petrified wood; 1 dart point tip, petrified wood; 1 dart point tip/blade, chert; 1 unidentified dart point fragment, petrified wood; 5 flake tools, chert; 1 core, Glover quartzite; 89 lithic debris, petrified wood; 76 lithic debris, chert; 1 lithic debris, ferruginous sandstone; 12 lithic debris, Glover quartzite; 15 lithic debris, quartzite; 6 fire-cracked rock, quartzite; 1 firecracked rock, petrified wood

1 brushed grog-tempered body sherd; 1 plain grogtempered rim sherd; 2 plain grog-tempered body sherds; 1 plain sandy paste sherd; 1 Godley dart point, quartzite; 1 Darl dart point, petrified wood; 2 Kent dart points, petrified wood; $1 \mathrm{cf}$. Lone Oak dart point, quartzite; 1 biface preform, petrified wood; 1 biface fragment, chert; 1 flake tool, petrified wood; 1 pitted stone, ferruginous sandstone; 1 mano, ferruginous sandstone; 101 lithic debris, petrified wood; 57 lithic debris, chert; 7 lithic debris, Glover quartzite; 20 lithic debris, quartzite

3 animal bones; 1 engraved grog-bone-tempered body sherd; 3 brushed body sherds (1 grog-tempered, 1 grogbone-hematite-tempered, 1 grog-bone-tempered); 2 plain sandy paste body sherd; 1 burned clay; 1 clay object (?); 1 cf. Godley dart point, petrified wood; $1 \mathrm{cf}$. Darl dart point, chert; 1 contracting stem dart point fragment, chert; 1 expanding stem dart point fragment, petrified wood; 1 biface fragment, chert; 1 grinding slab, ferruginous sandstone; 1 pitted stone, ferruginous sandstone; 8 lithic debris, Glover quartzite; 9 lithic debris, quartzite; 66 lithic debris, chert; 62 lithic debris, petrified wood; 6 fire-cracked rock, quartzite; 1 fire-cracked rock, ferruginous sandstone

1 plain grog-tempered body sherd; 1 lithic debris, Glover quartzite; 4 lithic debris, quartzite; 8 lithic debris, petrified wood; 11 lithic debris, chert

1 incised-punctated grog-tempered body sherd; 1 plain grog-tempered body sherd; 3 lithic debris, Glover quartzite; 12 lithic debris, petrified wood; 14 lithic debris, quartzite; 17 lithic debris, chert 
Unit 2, 10-20 cm

Unit 2, 20-30 cm

Unit 2, 30-40 cm

Unit 2, 40-50 cm

Unit 2, 50-60 cm

Unit 2, 60-70 cm
1 animal bone; 1 engraved grog-hematite-tempered rim sherd; 2 brushed body sherds (1 grog-bone-tempered, 1 grog-tempered); 1 plain sandy paste body sherd; 3 lithic debris, Glover quartzite; 6 lithic debris, quartzite; 13 lithic debris, chert; 18 lithic debris, petrified wood

1 punctated grog-tempered body sherd; 1 Gary dart point, chert; 4 lithic debris, Glover quartzite; 13 lithic debris, chert; 20 lithic debris, petrified wood; 14 lithic debris, quartzite

1 animal bone; 1 brushed grog-tempered body sherd; 1 plain grog-tempered rim sherd; 1 plain grog-hematitetempered body sherd; 1 plain grog-tempered body sherd; 1 grog-tempered base sherd; 2 biface fragments, petrified wood; 9 lithic debris, Glover quartzite; 22 lithic debris, chert; 21 lithic debris, quartzite; 58 lithic debris, petrified wood

1 animal bone; 1 brushed grog-tempered body sherd; 1 incised grog-bone-tempered body sherd; 1 plain grog-bonetempered body sherd; 1 plain sandy paste body sherd; 1 grog-hematite-tempered base sherd; 1 Gary dart point, petrified wood; 1 Friley arrow point, quartzite; 1 flake tool, chert; 1 core, quartzite; 7 lithic debris, Glover quartzite; 19 lithic debris, quartzite; 26 lithic debris, chert; 43 lithic debris, petrified wood

$1 \mathrm{cf}$. Steiner arrow point, petrified wood; 1 arrow point tip, petrified wood; 1 Kent dart point, petrified wood; 1 Gary dart point, petrified wood; 2 plain rim sherds (1 grogtempered, 1 sandy paste); 1 brushed grog-bone-tempered rim sherd; 1 brushed grog-tempered body sherd; 6 plain body sherds (4 grog-tempered, 1 grog-hematite-tempered, 1 sandy paste); 1 lithic debris, ferruginous sandstone; 5 lithic debris, Glover quartzite; 32 lithic debris, chert; 19 lithic debris, quartzite; 54 lithic debris, petrified wood

1 brushed grog-tempered body sherd; 1 plain grog-bonetempered body sherd; 1 plain sandy paste body sherd; 1 Gary dart point, quartzite; 1 Kent dart point, petrified wood; 1 flake tool, petrified wood; 1 biface preform, chert; 1 hammerstone fragment, quartzite; 11 lithic debris, quartzite; 25 lithic debris, chert; 13 lithic debris, quartzite; 54 lithic debris, petrified wood; 1 fire-cracked rock, quartzite 
Unit $2,70-80 \mathrm{~cm}$

Unit 3, 0-10 cm

Unit 3, 10-20 cm

Unit 3, 20-30 cm
1 engraved grog-hematite-tempered body sherd; 1 flake tool, petrified wood; 1 drill fragment, chert; 1 celt or axe, petrified wood; 1 core, chert; 1 core, Glover quartzite; 6 lithic debris, Glover quartzite; 56 lithic debris, petrified wood; 8 lithic debris, quartzite; 40 lithic debris, chert; 4 fire-cracked rocks, ferruginous sandstone

1 engraved grog-tempered body sherd; 1 brushed grogtempered body sherd; 1 brushed-punctated grog-tempered body sherd; 2 incised-punctated body sherds (1 grogtempered, 1 grog-bone-tempered); 2 plain grog-tempered body sherds; 1 grog-tempered base sherd; 1 biface fragment, quartzite; 3 lithic debris, chert; 2 lithic debris, Glover quartzite; 6 lithic debris, quartzite; 11 lithic debris, petrified wood

31 animal bones; 1 brushed bone-tempered rim sherd; 14 brushed body sherds ( 6 bone-tempered, 2 grog-bonetempered, 1 grog-tempered); 1 punctated body sherd; 3 incised-punctated body sherds (2 grog-tempered); 1 engraved body sherd; 2 engraved grog-tempered rim sherds; 5 plain rim sherds (4 grog-tempered); 20 plain body sherds (4 grog-tempered, 2 grog-bone-tempered); 1 plain bone-tempered body sherd; 2 grog-tempered base sherds; 1 plain pipe bowl sherd; 1 burned clay; 1 Perdiz arrow point, quartzite; 1 Perdiz arrow point, petrified wood; $1 \mathrm{cf}$. Perdiz arrow point, chert; $1 \mathrm{cf}$. Steiner arrow point, petrified wood; 97 lithic debris, petrified wood; 27 lithic debris, Glover quartzite; 43 lithic debris, quartzite; 56 lithic debris, chert

46 animal bones; 27 brushed (4 grog-tempered, 10 bonetempered, 7 bone-grog-tempered, 1 bone-hematitetempered) body sherds; 1 brushed-incised grog-tempered body sherd; 1 brushed-grooved bone-tempered body sherd; 2 brushed-punctated body sherds ( 1 bone-tempered); 5 engraved grog-tempered rim sherds; 1 engraved grogtempered body sherd; 1 pinched grog-tempered body sherd; 1 incised bone-tempered body sherd; 1 incised grogtempered rim sherd; 1 incised-punctated grog-hematitetempered rim sherd; 1 punctated grog-tempered body sherd; 1 plain rim sherd; 35 plain body sherds (9 grogtempered, 6 bone-tempered, 3 grog-bone-tempered; 2 groghematite-tempered); 1 plain rim/lip tab sherd; 1 plain sandy paste body sherd; 1 plain body-base grog-tempered sherd; 6 base sherds ( 1 bone-tempered, 1 bone-hematite-tempered, 2 grog-tempered); 2 plain sherdlets; 2 plain bone-tempered 
Unit 3, 30-40 cm

Unit 3, 40-50 cm

Unit 3A, 0-10 cm pipe bowl (Red River pipe) rim sherds; 19 burned clay; 1 Perdiz arrow point, Glover quartzite; 1 Perdiz arrow point, quartzite; 1 Perdiz arrow point, chert; 1 arrow point blade, petrified wood; 1 arrow point blade, Glover quartzite; 1 arrow point preform fragment, quartzite; 1 dart point tip, chert; 1 drill, chert; 1 flake tool, chert; 1 pitted stone, ferruginous sandstone; 148 lithic debris, petrified wood; 79 lithic debris, chert; 104 lithic debris, quartzite; 61 lithic debris, Glover quartzite

73 animal bones; 1 pipe bowl rim sherd; 1 engraved grogtempered rim sherd; 2 engraved grog-tempered body sherds; 1 incised grog-tempered rim sherd; 1 incised grogbone-tempered body sherd; 3 punctated body sherds (1 grog-tempered, 1 grog-hematite-tempered); 2 incisedpunctated body sherds (1 grog-tempered); 1 brushed grogtempered rim sherd; 3 brushed body sherds (1 grog-bonetempered, 1 grog-hematite-tempered); 1 brushed-punctated grog-hematite-tempered body sherd; 1 plain grog-tempered rim sherd; 14 plain body sherds ( 5 grog-tempered); 2 base sherds (1 grog-hematite-tempered); 3 plain body sherdlets; 14 burned clay; 1 arrow point blade, petrified wood; 63 lithic debris, petrified wood; 13 lithic debris, Glover quartzite; 52 lithic debris, quartzite; 34 lithic debris, chert; 3 fire-cracked rock, ferruginous sandstone

36 animal bones; 1 engraved/excised body sherd; 1 engraved grog-tempered rim sherd; 1 engraved grogtempered body sherd; 1 incised grog-tempered body sherd; 1 brushed body sherd; 1 incised grog-tempered rim sherd; 1 incised grog-tempered body sherd; 2 incised bone-tempered body sherds; 1 plain grog-hematite-tempered rim sherd; 2 plain grog-tempered rim sherds; 1 plain grog-hematitetempered rim sherd; 5 plain grog-hematite-tempered body sherds; 2 plain grog-tempered body sherds; 14 plain body sherds; 2 plain sandy paste body sherds; 2 base sherds (1 grog-tempered); 1 Red River pipe stem sherd; 5 burned clay; 4 daub; 1 biface fragment, quartzite; 1 bifacial scraper, petrified wood; 1 core, chert; 1 core, petrified wood; 1 core, Glover quartzite; 29 lithic debris, Glover quartzite; 41 lithic debris, quartzite; 34 lithic debris, chert; 58 lithic debris, petrified wood; 1 fire-cracked rock, petrified wood

4 plain body sherds (2 grog-bone-tempered, 2 grogtempered); 1 Perdiz arrow point, quartzite; 4 lithic debris, 
Unit $3 \mathrm{~A}, 10-20 \mathrm{~cm}$

Unit 3A, 20-30 cm

Unit 3A, 30-40 cm

Unit 3A, 40-50 cm

Unit 3A, 50-60 cm

Unit 3A, 60-70 cm

Unit 4, 0-10 cm

Unit 4, 10-20 cm

Unit 4, 20-30 cm chert; 4 lithic debris, quartzite; 2 lithic debris, Glover quartzite; 3 lithic debris, petrified wood

10 animal bones; 1 brushed grog-tempered rim sherd; 3 brushed grog-tempered body sherds; 4 plain body sherds ( 3 grog-tempered, 1 grog-bone-tempered); 1 grog-bonetempered base sherd; $1 \mathrm{cf}$. Steiner arrow point, quartzite; 1 petrified wood biface fragment; 21 lithic debris, chert; 33 lithic debris, quartzite; 30 lithic debris, petrified wood; 14 lithic debris, Glover quartzite

1 animal bone; 1 plain sandy paste body sherd; 11 lithic debris, petrified wood; 2 lithic debris, chert; 10 lithic debris, quartzite; 4 lithic debris, Glover quartzite

3 lithic debris, Glover quartzite; 5 lithic debris, chert; 13 lithic debris, quartzite; 20 lithic debris, petrified wood

1 Gary dart point, chert; 1 Gary dart point, petrified wood; 7 lithic debris, chert; 3 lithic debris, Glover quartzite; 11 lithic debris, quartzite; 20 lithic debris, petrified wood

$1 \mathrm{cf}$. Williams dart point, chert; 1 mano, Glover quartzite; 13 tested cobble, petrified wood; 10 lithic debris, quartzite; 6 lithic debris, chert; 1 lithic debris, petrified wood; 1 lithic debris, Glover quartzite

1 biface fragment, petrified wood; 17 lithic debris, petrified wood; 3 lithic debris, Glover quartzite; 17 lithic debris, quartzite; 9 lithic debris, chert

2 animal bones; 1 plain grog-tempered body sherd; $1 \mathrm{cf}$. Perdiz arrow point, quartzite; 1 arrow point blade fragment, petrified wood; 25 lithic debris, Glover quartzite; 59 lithic debris, petrified wood; 44 lithic debris, chert; 35 lithic debris, quartzite

6 animal bones; 1 incised grog-tempered body sherd; 1 punctated grog-tempered rim sherd; 19 lithic debris, Glover quartzite; 30 lithic debris, chert; 41 lithic debris, quartzite; 66 lithic debris, petrified wood

2 animal bones; 1 Perdiz arrow point, petrified wood; 1 arrow point blade, petrified wood; 1 biface, petrified wood; 1 flake tool, chert; 1 core, quartzite; 34 lithic debris, quartzite; 50 lithic debris, chert; 67 lithic debris, quartzite; 
Unit 4, 30-40 cm

Unit 4, 40-50 cm

Unit 4, 50-60 cm

Unit 4, 60-70 cm

Unit 4, 70-80 cm

Unit 4, 80-83 cm

Unit 4A, 0-10 cm
107 lithic debris, petrified wood; 1 fire-cracked rock, ferruginous sandstone

1 incised grog-bone-tempered body sherd; 28 lithic debris, Glover quartzite; 17 lithic debris, chert; 27 lithic debris, quartzite; 65 lithic debris, petrified wood

2 animal bones; 1 lip-notched sandy plain rim sherd; 1 plain sandy paste body sherd; 1 dart point blade, petrified wood; 2 biface fragments, petrified wood; 1 biface fragment, chert; 1 core, Glover quartzite; 1 lithic debris, ferruginous sandstone; 42 lithic debris, chert; 65 lithic debris, quartzite; 37 lithic debris, Glover quartzite; 87 lithic debris, petrified wood; 1 fire-cracked rock, quartzite

9 animal bones; 5 plain body sherds ( 1 sandy paste, 3 grogtempered, 1 hematite-tempered); 1 grog-tempered base sherd; 1 cf. Bulverde dart point, petrified wood; 1 unidentified dart point, chert; 1 biface, Glover quartzite; 1 biface preform, quartzite; 1 biface, quartzite; 1 flake tool, Glover quartzite; 2 flake tools, chert; 122 lithic debris, petrified wood; 45 lithic debris, Glover quartzite; 51 lithic debris, quartzite; 68 lithic debris, chert; 1 fire-cracked rock, quartzite

1 Gary dart point, chert; 1 Gary dart point, quartzite; 1 biface fragment, petrified wood; 2 biface tips, petrified wood; 2 flake tools, chert; 58 lithic debris, chert; 24 lithic debris, quartzite; 1 lithic debris, ferruginous sandstone; 1 lithic debris, hematite; 13 lithic debris, Glover quartzite; 73 lithic debris, petrified wood

1 Godley dart point, chert; 1 Gary dart point, quartzite; 1 biface fragment, quartzite; 1 biface fragment, petrified wood; 57 lithic debris, chert; 7 lithic debris, Glover quartzite; 5 lithic debris, quartzite; 60 lithic debris, petrified wood

$1 \mathrm{cf}$. Marcos dart point, chert; 4 lithic debris, quartzite; 2 lithic debris, ferruginous sandstone; 3 lithic debris, Glover quartzite; 27 lithic debris, chert; 26 lithic debris, petrified wood

1 burned clay; 1 lithic debris, Glover quartzite; 4 lithic debris, quartzite; 7 lithic debris, petrified wood 
Unit 4A, $10-20 \mathrm{~cm}$

Unit 4A, 20-30 cm

Unit 4A, 30-40 cm

Unit 4A, 40-50 cm

Unit 4A, 50-60 cm

Unit 4A, 60-70 cm

Unit 4A, 70-80 cm

Unit 4A, $80-90 \mathrm{~cm}$
4 plain grog-tempered body sherds; 1 grog-bone-tempered incised rim sherd; 1 grog-hematite-tempered incised body sherd; 1 plain grog-bone-tempered body sherd; 1 plain sandy paste rim sherd; 3 plain sandy paste body sherds; 1 grog-tempered base sherd; 2 burned clay; 1 contracting stem dart point fragment, petrified wood; 1 dart point tip, Glover quartzite; 2 biface fragments, petrified wood; 1 biface fragment, quartzite; 1 flake scraper, chert; 1 core, quartzite; 36 lithic debris, Glover quartzite; 53 lithic debris, quartzite; 71 lithic debris, chert; 150 lithic debris, petrified wood

1 animal bone; 3 plain body sherds (1 grog-hematite-bonetempered; 1 hematite-tempered); 22 lithic debris, quartzite; 54 lithic debris, petrified wood; 8 lithic debris, Glover quartzite; 11 lithic debris, chert

1 unifacial gouge, petrified wood; 21 lithic debris, petrified wood; 4 lithic debris, Glover quartzite; 8 lithic debris, chert; 9 lithic debris, quartzite

1 plain grog-tempered body sherd; 1 plain sandy paste body sherd; 18 lithic debris, petrified wood; 9 lithic debris, chert; 4 lithic debris, Glover quartzite; 23 lithic debris, quartzite

3 animal bones; 1 Gary dart point, Glover quartzite; 1 biface fragment, petrified wood; 1 fire-cracked rock, ferruginous sandstone; 1 fire-cracked rock, petrified wood

1 animal bone; 4 plain sandy paste body sherds; 1 plain bone-tempered body sherd; $1 \mathrm{cf}$. Edgewood dart point, petrified wood; 1 pitted stone, ferruginous sandstone; 1 core, quartzite; 51 lithic debris, petrified wood; 24 lithic debris, chert; 33 lithic debris, quartzite; 12 lithic debris, Glover quartzite; 3 fire-cracked rocks, ferruginous sandstone; 1 fire-cracked rock, Glover quartzite

5 animal bones; 1 plain grog-tempered rim sherd; 5 plain body sherds ( 2 sandy paste, 1 grog-hematite-tempered); 1 burned clay; 1 biface fragment, quartzite; 1 core, quartzite; 54 lithic debris, petrified wood; 13 lithic debris, chert; 8 lithic debris, Glover quartzite; 25 lithic debris, quartzite; 1 fire-cracked rock, ferruginous sandstone

7 animal bones; 1 brushed-punctated grog-hematite-bonetempered body sherd; 1 incised-punctated grog-tempered body sherd; $1 \mathrm{cf}$. Alba arrow point, petrified wood; 1 biface 
Unit 4A, 0-90 cm

Unit 5, 10-20 cm

Unit 5, 20-30 cm

Unit 5, 30-40 cm

Unit 5, 40-50 cm

Unit 5, 50-60 cm

Unit $5,60-70 \mathrm{~cm}$

Unit 5, 70-80 cm preform, quartzite; 1 biface fragment, petrified wood; 1 flake drill, petrified wood; 1 pitted stone, ferruginous sandstone; 1 core, quartzite; 25 lithic debris, Glover quartzite; 46 lithic debris, quartzite; 55 lithic debris, chert; 138 lithic debris, petrified wood; 1 fire-cracked rock, quartzite

3 lithic debris, chert; 3 lithic debris, petrified wood; 1 lithic debris, Glover quartzite; 5 lithic debris, quartzite

13 lithic debris, Glover quartzite; 9 lithic debris, quartzite; 16 lithic debris, petrified wood; 29 lithic debris, chert

2 arrow point blade fragments, petrified wood; 1 biface fragment, chert; 19 lithic debris, quartzite; 72 lithic debris, petrified wood; 84 lithic debris, chert; 31 lithic debris, Glover quartzite

1 flake tool, Glover quartzite; 72 lithic debris, petrified wood; 20 lithic debris, Glover quartzite; 15 lithic debris, quartzite; 73 lithic debris, chert

1 incised sandy paste body sherd; 1 Gary dart point, petrified wood; 29 lithic debris, Glover quartzite; 25 lithic debris, quartzite; 103 lithic debris, petrified wood; 102 lithic debris, chert

1 flake tool, petrified wood; 1 flake tool, chert; 71 lithic debris, chert; 15 lithic debris, Glover quartzite; 22 lithic debris, quartzite; 56 lithic debris, petrified wood; 1 firecracked rock, quartzite; 1 fire-cracked rock, ferruginous sandstone

1 animal bone; $1 \mathrm{cf}$. Clovis biface preform, chert; 1 Kent dart point, petrified wood; 1 Godley dart point, petrified wood; 1 expanding stem dart point fragment, quartzite; 1 biface fragment, quartzite; 1 flake tool, chert; 1 hammerstone, quartzite; 1 core, petrified wood; 22 lithic debris, Glover quartzite; 18 lithic debris, quartzite; 84 lithic debris, chert; 70 lithic debris, petrified wood

2 burned clay; $1 \mathrm{cf}$. Neches River dart point, petrified wood; 1 dart point tip, chert; 1 dart point blade/tip, petrified wood; 1 biface fragment, petrified wood; 2 biface fragments, chert; 1 flake tool, chert; 1 gouge, petrified wood; 1 core, Glover quartzite; 22 lithic debris, Glover quartzite; 104 lithic debris, chert; 18 lithic debris, quartzite; 
Unit 5, 80-90 cm

Unit 6, 0-10 cm

Unit $6,10-20 \mathrm{~cm}$

Unit 6, 20-30 cm

Unit 6, 30-40 cm

Unit 6, 40-50 cm
106 lithic debris, petrified wood; 2 fire-cracked rocks, quartzite; 1 fire-cracked rock, ferruginous sandstone

1 Godley dart point, petrified wood; 1 mano-pitted stone, ferruginous sandstone; 1 core, quartzite; 6 lithic debris, Glover quartzite; 2 lithic debris, quartzite; 25 lithic debris, petrified wood; 48 lithic debris, chert; 1 fire-cracked rock, ferruginous sandstone

2 animal bones; 1 plain elbow pipe or bottle neck rim sherd, grog-bone-tempered; 2 plain grog-tempered body sherds; 1 Perdiz arrow point, quartzite; 1 arrow point tip, Glover quartzite; 68 lithic debris, petrified wood; 1 lithic debris, ferruginous sandstone; 11 lithic debris, Glover quartzite; 25 lithic debris, chert; 28 lithic debris, quartzite

4 animal bones; 1 engraved grog-bone-tempered body sherd; 1 incised sandy paste body sherd; 1 punctated grogtempered body sherd; 1 plain grog-tempered body sherd; 1 Perdiz arrow point, chert; 1 Gary dart point, petrified wood; 82 lithic debris, petrified wood; 13 lithic debris, Glover quartzite; 35 lithic debris, quartzite; 44 lithic debris, chert; 1 fire-cracked rock, ferruginous sandstone

4 animal bones; 2 engraved grog-bone-tempered body sherds; 3 plain grog-tempered body sherds; 1 unidentified dart point, chert; 2 biface fragments, quartzite; 30 lithic debris, chert; 17 lithic debris, Glover quartzite; 78 lithic debris, petrified wood; 28 lithic debris, quartzite; 1 firecracked rock, quartzite

1 animal bone; 1 incised grog-tempered body sherd; 2 plain rim sherds ( 1 grog-tempered); 4 plain body sherds ( 2 grogtempered); 1 grog-tempered base sherd; 1 arrow point tip, petrified wood; $1 \mathrm{cf}$. Bulverde dart point, chert; 2 biface fragments, quartzite; 1 core, petrified wood; 82 lithic debris, petrified wood; 27 lithic debris, chert; 14 lithic debris, Glover quartzite; 23 lithic debris, quartzite; 2 firecracked rocks, ferruginous sandstone

1 plain sandy paste body sherd; 2 plain grog-tempered body sherds; 1 cf. Neches River dart point, petrified wood; 1 Lone Oak dart point, petrified wood; 1 unidentified contracting stem dart point, petrified wood; 1 Perdiz arrow point, petrified wood; 1 biface fragment, quartzite; 1 biface fragment, chert; 77 lithic debris, petrified wood; 15 lithic 
Unit 6, 50-60 cm

Unit 6, 60-70 cm

Unit 6, 70-80 cm

Unit 6, west wall

Unit 7, 0-10 cm

Unit 7, 10-20 cm debris, Glover quartzite; 29 lithic debris, quartzite; 35 lithic debris, chert

2 animal bones; 1 plain grog-tempered body sherd; 1 plain sandy paste body sherd; $1 \mathrm{cf}$. Bulverde dart point, chert; 1 unidentified dart point fragment, petrified wood; 1 dart point tip, chert; 1 flake tool, petrified wood; 2 flake tools, chert; 1 pitted stone, ferruginous sandstone; 69 lithic debris, petrified wood; 14 lithic debris, Glover quartzite; 37 lithic debris, chert; 20 lithic debris, quartzite; 3 lithic debris, ferruginous sandstone; 2 fire-cracked rock, ferruginous sandstone; 2 fire-cracked rock, quartzite

2 animal bones; 1 plain grog-hematite-tempered rim sherd; 4 plain sandy paste body sherds (1 with suspension hole); 1 plain grog-tempered body sherd; 1 Kent dart point, quartzite; 1 Kent dart point, petrified wood; 1 bifacial preform, petrified wood; 1 biface, petrified wood; 2 flake tools, chert; 1 mano-pitted stone, ferruginous sandstone; 1 core, quartzite; 1 core, Glover quartzite; 1 core, petrified wood; 2 cores, chert; 100 lithic debris, petrified wood; 14 lithic debris, Glover quartzite; 18 lithic debris, quartzite; 55 lithic debris, chert; 1 fire-cracked rock, ferruginous sandstone; 3 fire-cracked rocks, quartzite

1 Morrill dart point, petrified wood; $1 \mathrm{cf}$. Dawson dart point, chert; 1 contracting stem dart point fragment, novaculite; 1 dart point preform, quartzite; 1 biface, petrified wood; 1 biface, chert; 1 flake tool, chert; 2 cores, petrified wood; 1 core fragment, quartzite; 19 lithic debris, Glover quartzite; 65 lithic debris, petrified wood; 26 lithic debris, chert; 19 lithic debris, quartzite; 1 fire-cracked rock, Glover quartzite; 1 fire-cracked rock, petrified wood; 1 fire-cracked rock, ferruginous sandstone; 2 fire-cracked rocks, quartzite

1 incised sandy paste body sherd; 1 end scraper, chert

$1 \mathrm{cf}$. Perdiz arrow point, petrified wood; 20 lithic debris, chert; 19 lithic debris, Glover quartzite; 81 lithic debris, petrified wood; 41 lithic debris, quartzite

2 animal bones; 7 lithic debris, Glover quartzite; 7 lithic debris, chert; 9 lithic debris, quartzite; 26 lithic debris, petrified wood 
Unit 7, 20-30 cm

Looter Pit 3

Looter Pit 4

Looter Pit 5

Looter Pit 8
16 lithic debris, quartzite; 3 lithic debris, Glover quartzite; 15 lithic debris, chert; 32 lithic debris, petrified wood

5 animal bones; 1 plain body sherd; 1 plain bone-hematitetempered body sherd; 1 plain grog-tempered body sherd; 1 plain grog-hematite-tempered body sherd; 1 plain hematitetempered body sherd; 1 plain sandy paste rim sherd; 4 plain sandy paste body sherd; 1 brushed-punctated grog-bonehematite-tempered body sherd; 3 pieces of burned clay; 1 cf. Dawson dart point, petrified wood; 1 Gary dart point, petrified wood; 1 Yarbrough dart point, chert; 1 Kent dart point, petrified wood; 1 Woden dart point, petrified wood; 2 Morrill dart points, petrified wood; 1 dart point tip, chert; 1 Steiner arrow point, petrified wood; 1 Friley arrow point, quartzite; 1 flake tool, petrified wood; 72 lithic debris, petrified wood; 22 lithic debris, chert; 23 lithic debris, Glover quartzite; 62 lithic debris, quartzite; 4 fire-cracked rocks, quartzite; 1 fire-cracked rock, ferruginous sandstone

1 animal bone; 1 plain grog-tempered body sherd; 1 Morrill dart point, chert; 1 lithic debris, quartzite; 7 lithic debris, petrified wood

5 animal bones; 1 pinched bone-tempered body sherd; 1 plain grog-tempered rim sherd; 1 grog-tempered base sherd; 1 grog-tempered incised body sherd; 9 plain body sherds (7 grog-tempered, 1 grog-hematite-tempered); 2 plain sandy paste body sherds; 1 biface fragment, petrified wood; 1 side scraper, chert; 1 ochre pigment stone; 124 lithic debris, petrified wood; 34 lithic debris, chert; 71 lithic debris, quartzite; 37 lithic debris, Glover quartzite; 1 Glover quartzite core; 1 fire-cracked rock, quartzite; 4 firecracked rocks, ferruginous sandstone

4 animal bones; 1 grog-tempered incised body sherd; 1 plain bone-tempered body sherd; 5 plain grog-tempered body sherds; 1 plain grog-hematite-tempered body sherd; 1 plain sandy paste rim sherd; 5 plain sandy paste body sherds ( 1 with suspension hole); 1 engraved grog-hematitetempered body sherd; 1 burned clay; 1 parallel stemmed dart point, petrified wood; 1 Gary dart point, quartzite; 2 dart point tip fragments, quartzite; 2 dart point tips, petrified wood; 1 arrow point blade/tip, petrified wood; 2 biface fragments, chert; 1 biface fragment, petrified wood; 3 flake tools, chert; 1 unifacial gouge, petrified wood; 1 core, quartzite; 1 core, chert; 1 tested cobble, Glover quartzite; 377 lithic debris, petrified wood; 189 lithic 
debris, chert; 131 lithic debris, quartzite; 75 lithic debris, Glover quartzite; 3 fire-cracked rock, quartzite; 2 firecracked rocks, ferruginous sandstone 


\section{APPENDIX 2, INVENTORY OF ARTIFACTS FROM HC-3}

Unit 1, 0-10 cm

Unit 1, 10-20 cm

Unit 1, 20-30 cm

Unit 1, 30-40 cm

Unit 1, 40-50 cm

Unit 1, 50-60 cm

Unit $1,60-70 \mathrm{~cm}$

Unit 1, wall

Hole 2
1 flake tool, petrified wood; 13 lithic debris, petrified wood; 5 lithic debris, quartzite; 2 lithic debris, Glover quartzite; 18 lithic debris, chert; 2 plain sandy paste body sherds

2 flake tools, chert; 10 lithic debris, petrified wood; 1 lithic debris, ferruginous sandstone; 1 lithic debris, Glover quartzite; 9 lithic debris, quartzite; 20 lithic debris, chert; 2 plain sandy paste body sherds

cf. Bulverde dart point, gray chert; 1 lithic debris, Glover quartzite; 4 lithic debris, quartzite; 7 lithic debris, petrified wood; 26 lithic debris, chert; 3 plain sandy paste body sherds; 2 plain grog-hematite-tempered body sherds; 1 plain grog-tempered body sherd

dart point fragment, gray chert; dart point fragment, dark gray chert; 15 lithic debris, petrified wood; 5 lithic debris, quartzite; 19 lithic debris, chert

Kent dart point, grayish-brown chert; Kent dart point, petrified wood; dart point blade/tip, petrified wood; 1 bifacial tool fragment, chert; 2 lithic debris, Glover quartzite; 12 lithic debris, petrified wood; 3 lithic debris, quartzite; 26 lithic debris, chert; 1 plain grog-hematitetempered body sherd

1 flake tool, quartzite; 1 mano fragment, quartzite; 19 lithic debris, petrified wood; 1 lithic debris, Glover quartzite; 1 lithic debris, hematite; 3 lithic debris, quartzite; 22 lithic debris, chert

1 hammerstone, quartzite; 1 lithic debris, ferruginous sandstone; 14 lithic debris, petrified wood; 14 lithic debris, chert

1 lithic debris, chert

1 flake tool, chert; 1 lithic debris, Manning Fused Glass; 1 plain grog-hematite-tempered body sherd 


\section{APPENDIX 3, INVENTORY OF ARTIFACTS FROM 41 HO13 AND HC-1}

\section{$41 \mathrm{HO13}$}

Unit 1, 40-50 cm

Unit 1, 100-110 cm

Unit 1, 110-120 cm

Unit 2, 60-70 cm

\section{HC-1}

Unit 1A, 30-40 cm

Unit 1A, 80-90 cm

Unit 1 back dirt

Unit 2, 10-20 cm

Unit 2A, $10-20 \mathrm{~cm}$
1 arrow point, cf. Steiner, gray chert

1 Kent dart point, petrified wood

1 ground stone tool fragment, quartzite

1 flake tool, gray chert

1 lithic debris, quartzite

1 Kent dart point, petrified wood

1 Gary dart point, petrified wood; 1 plain sandy paste rim sherd

1 incised-punctated body sherd

1 dart point blade/tip, petrified wood 